\title{
YUECHENG ZHANG GLYCOSYLATION IN CANCER AND INFECTION - THE ROLE OF SIALIC ACID
}

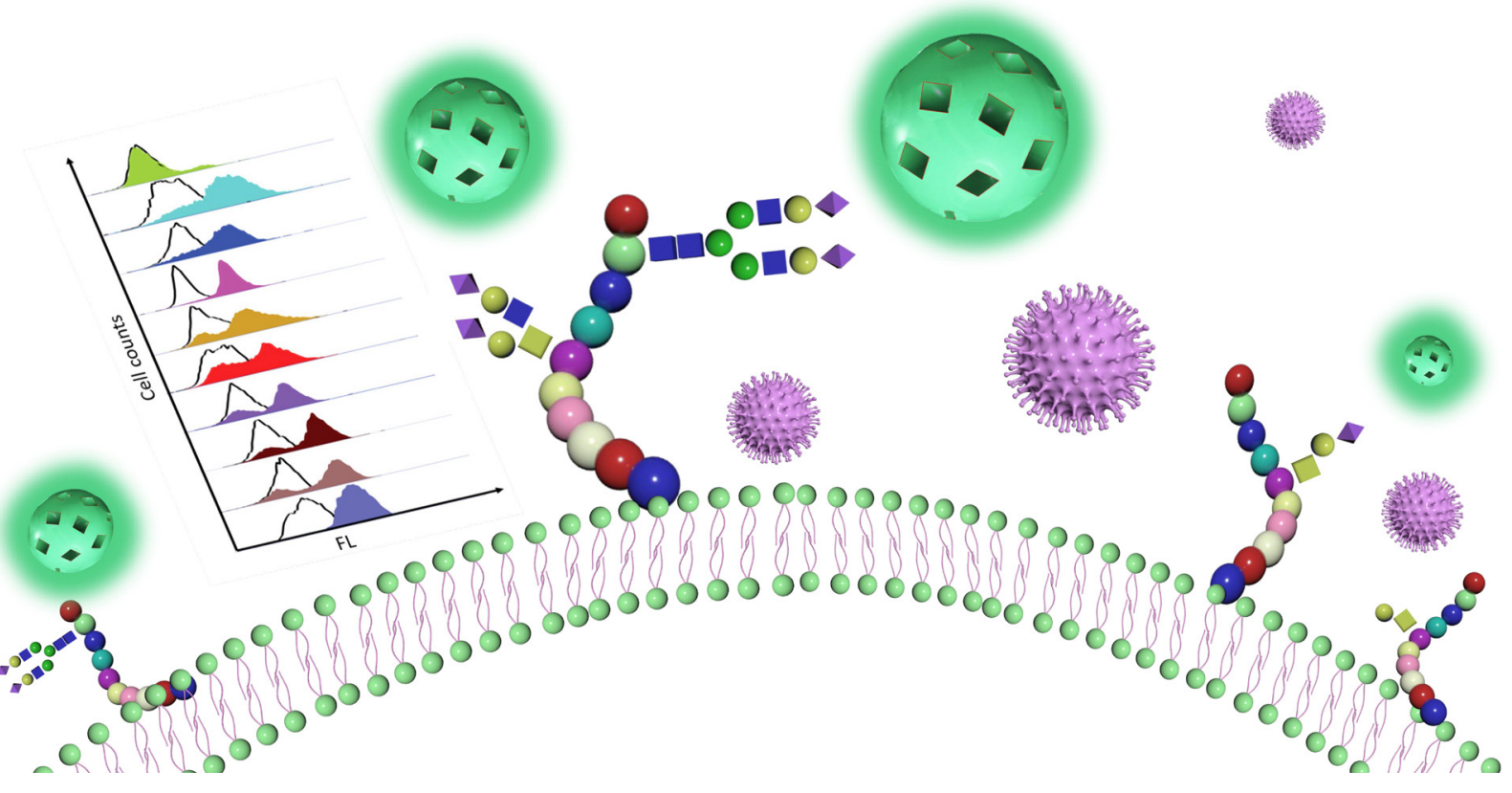



GLYCOSYLATION IN CANCER AND INFECTION

- THE ROLE OF SIALIC ACID 


\section{Publication Malmö University}

Health and Society, Doctoral Dissertation 2021:7

(C) Copyright Yuecheng Zhang, 2021

Front illustration: Sialic acids and their artificial receptors, MIPs

ISBN 978-91-7877-220-9 (print)

ISSN 978-91-7877-221-6 (pdf)

ISSN 1653-5383

DOI 10.24834/isbn.9789178772216

Printing: Holmbergs, Malmö 2021 


\section{YUECHENG ZHANG GLYCOSYLATION IN CANCER AND INFECTION}

- The Role of Sialic Acid

Malmö University, 2021

Health and society 
The good thing about science is that it's true whether or not you believe in it.

— Neil deGrasse Tyson 


\section{CONTENT}

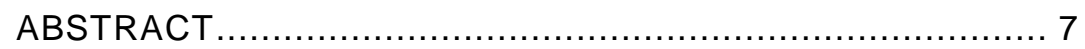

POPULÄRVETENSKAPLIG SAMMANFATTNING ............... 9

LIST OF PUBLICATIONS ..............................................

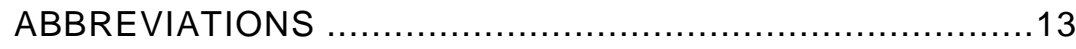

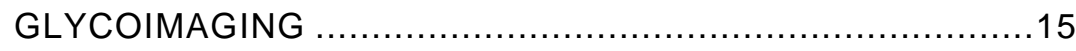

INTRODUCTION ........................................................ 17

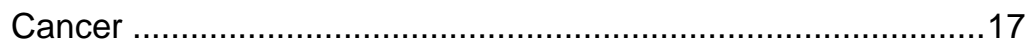

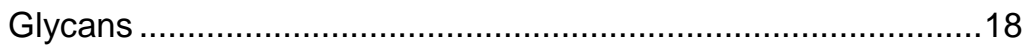

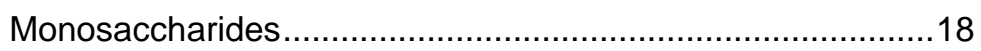

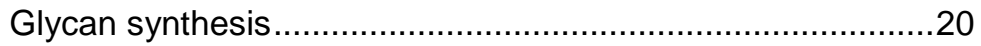

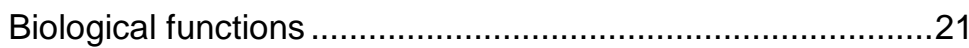

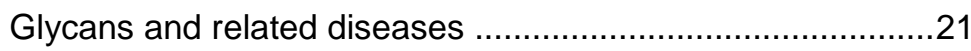

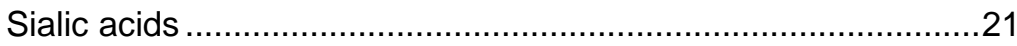



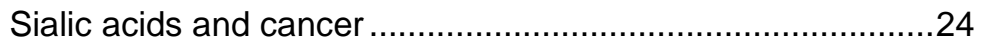

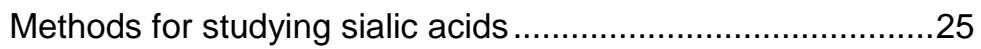

Molecularly imprinted polymers ...............................................25

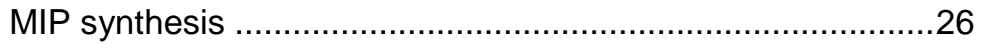

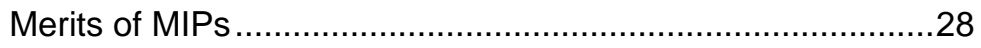

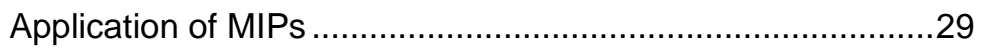

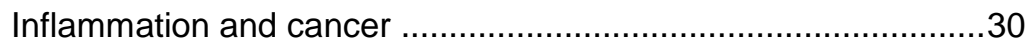

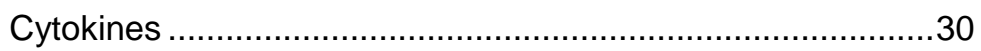




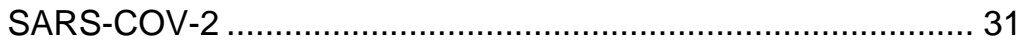

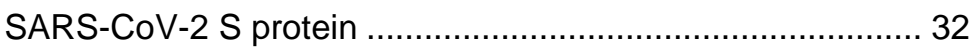

Angiotensin-converting enzyme 2 (ACE2) receptor .............. 33

TMPRSS2 and other co-factors ........................................... 33



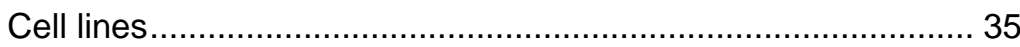

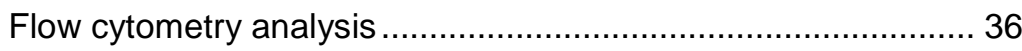

Lectin staining (Paper I-IV) ............................................... 36

SA-MIP staining (Paper I-III) .................................................. 36

Pre-treatment of SA-MIPs with SA conjugates (Paper I, III) .. 36

Neuraminidase treatment (Paper IV) .................................. 37

ACE2 and TMPRSS2 staining (Paper IV)............................ 37

Fluorescence microscopy (Paper I-II) .................................... 37

Stimulation of Jurkat cells (Paper III) ........................................ 38

ELISA analysis for IL-2, IL-6, IL-8 and TNF- $\alpha$ (Paper III) ........... 38

Quantitative reverse transcription PCR (Paper IV) .................... 39

RESULTS AND DISCUSSION .................................. 40

CONCLUSIONS AND FUTURE PERSPECTIVES ................45

ACKNOWLEDGEMENTS ......................................... 47






\section{ABSTRACT}

Sialic acids (SA), a group of nine-carbon backbone monosaccharides are abundantly expressed in vertebrates. They are usually linked to the terminal of glycan chains and play crucial roles in many biological processes, including cell adhesion, cell-cell interactions, immune modulation, cancer cell migration and invasion, as well as viral infections. To analyze and monitor SA expression, antibodies and glycan-binding lectins are typically used. However, high costs and poor stability limit the application in SA analysis. To overcome these drawbacks, an imprinting technique was used to synthesize an alternative SA receptor - SA molecularly imprinted polymers (SA-MIPs). Fluorescent molecules are embedded into the MIPs, facilitating the detection of MIPs binding to cells by flow cytometry and fluorescence microscopy. Firstly, core-shell SA imprinted MIPs were used to analyze SA expression in a panel of breast cancer cell lines. The SA expression of these cell lines was also tested by using the two glycan-binding lectins, MAL and SNA, which recognize $\alpha 2,3$ and $\alpha 2,6 \mathrm{SA}$, respectively. Our results show that breast cancer cell lines express $\alpha 2,3$ and $\alpha 2,6$ SA dissimilarly, and hence present different SA-MIP binding patterns. The specificity of SA-MIPs was further verified by an inhibition assay using two pentavalent SA conjugates that interfere with the SAMIPs. Furthermore, the SA-MIP synthesis protocol has been improved by using silica-coated polystyrene particles. The polystyrene core particles are lighter and smaller, increasing MIP suspensibility and augmenting MIP-cancer cell interactions. The cancer cell binding properties and the specificity have been verified by using thirteen different cancer cell lines, showing that the SA-MIPs can be used as effective tools for SA expression analysis. The SA-MIPs were used to analyze the SA expression of in vitro cultured cells treated with soluble cytokines to mimic the tumor microenvironment. The SA expression of two cancer cell lines stimulated with soluble cytokines was analyzed by using lectins and SA-MIPs. The MIP 
binding data correlated well with lectin staining results, demonstrating the potential of SA-MIPs to be used in the analysis of overexpressed SA in the tumor microenvironment. Furthermore, the involvement of SA in the infection of severe acute respiratory syndrome coronavirus 2 (SARS-CoV-2) was assessed. The viral surface receptor-binding domain (RBD) recognizes and conjugates with receptors on host cells, triggering the infection. Although the interaction between the RBD and host cells has been extensively studied, the mechanism behind this reaction is not fully determined. In this study, the interaction between the viral RBD and a panel of human cell lines from tissues susceptible to viral infection was tested. Moreover, the role of SA in this interaction has also been tested and evaluated. 


\section{POPULÄRVETENSKAPLIG SAMMANFATTNING}

Cancer är en ledande dödsorsak globalt och varje år dör cirka 9 miljoner människor runt om i världen. Oftast är det svårt att diagnostisera cancer i ett tidigt stadium. Om cancern har metastaserat och spridit sig till andra organ blir chansen att bli frisk väldigt liten. Det är en utmaning för forskare att hitta cancer i tidigt stadium.

Sialinsyra är en sockergrupp, eller en del av kolhydratstrukturer, som bekläder yttersta delen på cellytans proteiner och lipider. Sialinsyra spelar avgörande roller i många biologiska processer, inklusive cellers inbindning, cell-cell interaktion och virusinfektion. Sialinsyra på cancerceller kan bidra till cancercellers förflyttning och invasion till nya organ i kroppen. Därför kan det onormala mönstret av sialinsyra fungera som ett verktyg, som visar cancercellernas status. Det är svårt att mäta sialinsyra för det är inte lätt att producera antikroppar mot specifika kolhydratstrukturer. Man kan använda en sorts sockerbindande molekyler, lektiner, men oftast binder de till flera olika kolhydratstrukturer. Det finns stort behov av att utveckla nya verktyg för att analysera sialinsyra. För att övervinna dessa svårigheter, producerade vi fluorescerande molekylärt präglade polymerer mot sialinsyra, ett slags partiklar av plast, eller "plastantikroppar", som kan känna igen sialinsyra och därefter binda.

Dessa partiklar användes för att analysera sialinsyrauttryck i en grupp av bröstcancercellinjer. Resultaten verifierades vidare med två sialinsyraspecifika lektiner. Specificiteten för inbindning till sialinsyra hos dessa molekylärt präglade polymerer har också testats med en inhiberingsanalys med hjälp av användning av två sialinsyrahämmare. Våra resultat visar att bindningen inhiberades, vilket tyder på att polymererna kan binda till just sialinsyra. I arbete II har de molekylärt präglade polymererna mot sialinsyra förbättrats genom att mindre partiklar med ett lättare 
material producerats, och jämförts med de olika partiklarna från arbete I. Sialinsyrauttrycket har analyserats på tretton olika cancercellinjer. Vi fann att dessa molekylärt präglade polymerer som är mindre har hög förmåga att binda specifikt till sialinsyra på cancerceller, vilket gör de mer potenta att användas som effektivt verktyg för analys av sialinsyra. Vidare användes dessa partiklar för att analysera det förändrade sialinsyrauttrycket i en tumörmiljö som efterliknar den i kroppen, i arbete III. Tumörmiljön aktiverades genom stimulering av immunceller, vilket i sin tur leder till en inflammatorisk miljö. Våra resultat visar att de molekylärt präglade polymerernas bindning korrelerade väl med lektinbindning. Vi konkluderar att dessa partiklar kan användas för att analysera förändrat sialinsyrauttryck i tumörmiljön.

Sialinsyra finns ytterst på proteiner och lipider på cellytan och är även involverad $\mathrm{i}$ vissa virusinfektioner. Bland annat är sialinsyra receptor för influensaviruset, som använder sockerstrukturen för att binda in till och infektera våra celler. COVID-19pandemin orsakas av coronaviruset SARS-CoV-2. Även om interaktionen mellan virus och värdceller har studerats utförligt, är rollen för sialinsyra i SARS-CoV-2infektion fortfarande oklar. I arbete IV testades bindningen mellan receptorbindande domän, RBD, och en grupp av cellinjer från olika vävnader som kan vara mottagliga för SARS-CoV-2 virusinfektion. Sialinsyras roll har testats och utvärderats, men våra resultat tyder inte på att sialinsyra har en roll för SARS-CoV-2 viruset.

Sammanfattningsvis tar denna avhandling ett steg längre inom sialinsyraforskning, vilket kan bidra till utveckling av nya verktyg för analys av sialinsyror och sialinsyrarelaterad cancerdiagnos, samt patogeninfektioner. 


\section{LIST OF PUBLICATIONS}

\section{Paper I}

El-Schich, Z., Zhang, Y., Göransson, T., Dizeyi, N., Persson, J.L., Johansson, E., Caraballo, R., Elofsson, M., Shinde, S., Sellergren, B. and Wingren, A.G., 2021. Sialic Acid as a Biomarker Studied in Breast Cancer Cell Lines In Vitro Using Fluorescent Molecularly Imprinted Polymers. Applied Sciences, 11(7), p.3256.

\section{Paper II}

Beyer, S., Kimani, M., Zhang, Y., Verhassel, A., Sternbæk, L., Wang, T., Persson, J.L., Härkönen, P., Johansson, E., Caraballo, R., Elofsson, M., Gawlitza, K., Rurack, K., Ohlsson, L., El-Schich, Z., Wingren, A.G., and Stollenwerk, M.M, 2021. Improved biomarker detection analysis of glycosylated cell surface structures using sialic acid-targeted fluorescent core-shell particles (Manuscript)

\section{Paper III}

Zhang, Y., Llapashtica, K., Shinde, S., Sellergren, B., El-Schich, Z. and Wingren, A.G., 2019. Determination of cytokine regulated glycan expression by using molecularly imprinted polymers targeting sialic acid. Journal of cancer metastasis and treatment; 5, 56 . 


\section{Paper IV}

Zhang, Y., Sjöberg, T., Beyer, S., Laguitan, R.V., Johansson, E., Arnberg, N., Elofsson, M., Persson, J.L., Sellergren, B., Ohlsson, L., El-Schich, Z., Stollenwerk, M.M. and Wingren, A.G., 2021. SARS-CoV-2 spike protein interaction with cell types from tissue susceptible to viral infection (Manuscript)

\section{Additional publications not included in this thesis.}

1. El-Schich, Z., Zhang, Y., Feith, M., Beyer, S., Sternbæk, L., Ohlsson, L., Stollenwerk, M.M. and Wingren, A.G., 2020. Molecularly imprinted polymers in biological applications. BioTechniques, 69(6), pp.406-419.

2. Feith, M., Zhang, Y., Persson, J.L., Balvan, J., El-Schich, Z. and Wingren, A.G., 2021. Discrimination of sparsely glycosylated colorectal cancer cells and white blood cells using digital holographic cytometry as a novel in vitro-based circulating tumor cell model (Manuscript in preparation)

\section{Contributions}

Paper I. Took part in cell-based experiment and participated in the data analysis and manuscript preparation.

Paper II. Took part in the designing of experiments and performed cell-based experiments. Participated in the evaluation of the results. Prepared the graphic material and wrote the first draft of manuscript.

Paper III. Performed the experiment and participated in data analysis. Involved in the graphic material and manuscript preparation.

Paper IV. Took part in the designing of experiments and performed large part of the experimental work. Participated in the evaluation of the results. Prepared the graphic material and wrote the first draft of manuscript. 


\section{ABBREVIATIONS}

ACE2

CDG

CMP

FBS

Fuc

Gal

GalNAc

GBPs

GDP

Glc

GlcA

GlcNAc

GTs

HCoVs

MAL

Man

MERS-CoV

MIPs

Neu5Ac

PEST

PHA

PTM

QDs

RAS

RBD

RT
Angiotensin-converting enzyme 2

Disorders of glycosylation

Cytidine monophosphate

Fetal bovine serum

Fucose

Galactose

$N$-acetylgalactosamine

Glycan-binding proteins

Guanosine diphosphate

Glucose

Glucuronic acid

$\mathrm{N}$-acetylglucosamine

Glycosyltransferases

Human coronavirus

Maackia Amurensis Lectin

Mannose

Middle East respiratory syndrome-CoV

Molecularly imprinted polymers

$N$-Acetylneuraminic acid

Penicillin streptomycin

Phytohemagglutinine

Post-translational modifications

Quantum dots

Renin-angiotensin system

Receptor-binding domain

Room temperature 
SA

SARS-CoV

SARS-CoV-2

SIPs

SNA

STs

TDP

TMPRSS2

UDP

$\mathrm{Xyl}$
Sialic Acid

Severe acute respiratory syndrome coronavirus

Severe acute respiratory syndrome coronavirus 2

Surface-imprinted polymers

Sambucus Nigra Lectin

Sialyltransferases

Thymidine diphosphate

Transmembrane serine protease 2

Uridine diphosphate

Xylose 


\section{GLYCOIMAGING}

This study has been carried out within the framework of Marie Skłodowska-Curie Actions European Training Network (ETN) "GlycoImaging: Imprinted sialic acid nanoparticles for cancer associated biomarker detection".

Within this project, biologists and chemists from 5 research groups, spread across 5 universities and institutes and 3 industrial partners in 4 different countries work together with the aim of developing the next generation tools for cancer research and diagnostics.

The European project provided an excellent platform with close collaboration between academic and industrial partners. This project also offers courses, workshops, and other training events.

The studies related to this dissertation are mainly involved in "SA-MIP nanoparticles as diagnostic tools (work package 1)" and "Fluorescently responsive SA-MIP nanoparticles (work package 2)". The molecularly imprinted polymers were provided by the Federal Institute for Materials Research and Testing (BAM), Germany. Umeå University, the University of Turku, and Phase Holographic Imaging (PHIAB) assisted with cell analysis and staining, and the University of Copenhagen provided gene-engineered cell lines and insights into glycomics. 


\section{INTRODUCTION}

\section{Cancer}

Cancer is a group of diseases involving abnormal cells that grow uncontrollably, with the potential to invade and spread to other parts of the body [1]. There are more than 100 types of cancer, and lung, prostate, breast, cervix, colorectal, stomach, and liver cancer are the most common types in humans. According to World Health Organization (WHO), cancer caused approximately 9.6 million deaths globally in 2018, accounting for one in six deaths [2].

Cancer metastasis, which accounts for about $90 \%$ of cancer deaths, is the major cause for the high mortality of cancer [1, 3, 4]. In cancer metastasis, cancer cells break away from the primary tumor and spread through blood vessels or lymphatic vessels to tissues and organs other than the primary tumor site. Cancer metastasis involves a complex succession of biological steps. First of all, metastatic tumor cells detach from the primary tumor and the detached tumor cells exit through the basement membrane, the surrounding extracellular matrix, and the endothelium. Then, the metastatic tumor cells travel in lymphatic or blood vessels and spread to other parts of the body. After adhering to the endothelium of capillaries of the target organ site, the tumor cells invade through the endothelial cells and the surrounding basement membrane and finally grow to a secondary tumor $[1,5,6]$.

Once cancers spread to the body beyond the initial primary site, they usually become highly incurable [1, 7]. Therefore, it is well recognized that cancer patients diagnosed at an early stage are more likely to be successfully treated. Thus, the major challenge in the war against cancer is to diagnose cancer at an early stage. 
This requires both reliable biomarkers and sensitive/effective diagnostic tools to recognize the malignant cellular state early in the process.

\section{Glycans}

Glycans, or polysaccharides, are carbohydrate-based polymers linked to cell surface proteins or lipids [8]. They are indispensable in many biological processes, including cell adhesion, cell migration, cell-cell interactions, glycoprotein folding, cell signaling, and immune modulation [9, 10]. Glycans are essential building blocks, as universal in nature as nucleic acids, proteins, and lipids [9]. Different from the template-driven assembly of proteins and nucleic acids, biosynthesis of glycans is much more complex and include more combinatorial possibilities [8, 11]. Hence, glycans have structurally diversified structures and belong to a rapidly evolving group of molecules.

\section{Monosaccharides}

Monosaccharides are the basic units of glycans [12]. In mammalian cells, glycans are comprised of nine common monosaccharides, including glucose (Glc), galactose (Gal), $N$-acetylglucosamine (GlcNAc), $N$-acetylgalactosamine (GalNAc), mannose (Man), fucose (Fuc), xylose (Xyl), glucuronic acid (GlcA) and sialic acid ( $N$ Acetylneuraminic acid (Neu5Ac) is the most common form of sialic acid, Figure 1) [12]. These monosaccharides can be conjugated to form oligosaccharides or polysaccharides/glycans. 


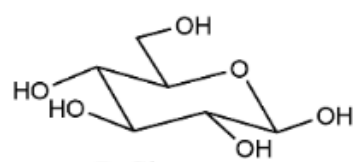

D-Glucose

(Glc)

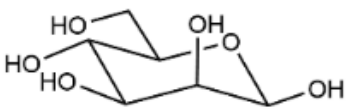

D-Mannose

(Man)

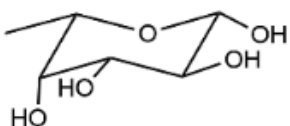

L-Fucose

(Fuc)



$N$-Acetyl-D-glucosamine

(GlcNAc)

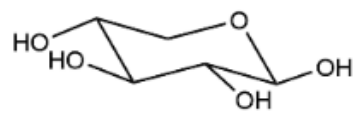

D-Xylose

(Xyl)

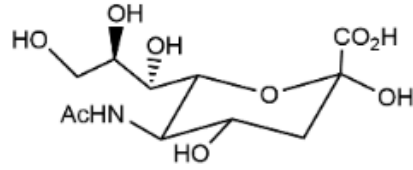

$\mathrm{N}$-Acetylneuraminic acid (Neu5Ac)

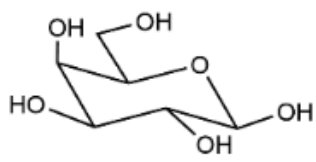

D-Galactose

(Gal)

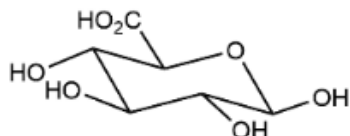

D-Glucuronic acid

(GlcA)

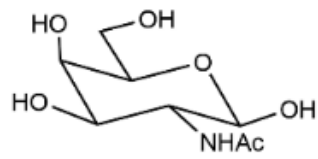

$N$-Acetyl-D-galactosamine (GalNAc)

Figure 1. Nine common monosaccharides occurring in mammalian cells. $N$ Acetylneuraminic acid (Neu5Ac) is the most common form of sialic acid [12].

In living systems, glycosylation is extensive, and it is one of the most abundant and diverse post-translational modifications (PMT) in nature [11, 13]. First of all, the different monosaccharides can link to each other with either $\alpha$ or $\beta$ glycosidic bonds, and they can be assembled in multiple ways, forming linear or branched glycan structures [14]. Also, a large number of additional modifications including sulfation, acetylation and methylation can occur at various positions of glycan chains [15]. These features imply the potential existence of around $10^{12}$ different glycan structures [16]. Moreover, based on the glycosidic bonds, glycans can attach to other biomolecules, such as proteins, lipids or RNAs [17]. Dependent on the different initiating sites and structures, glycans are classified accordingly, e.g., glycoproteins, glycosphingolipids, and proteoglycans (Figure 2). 


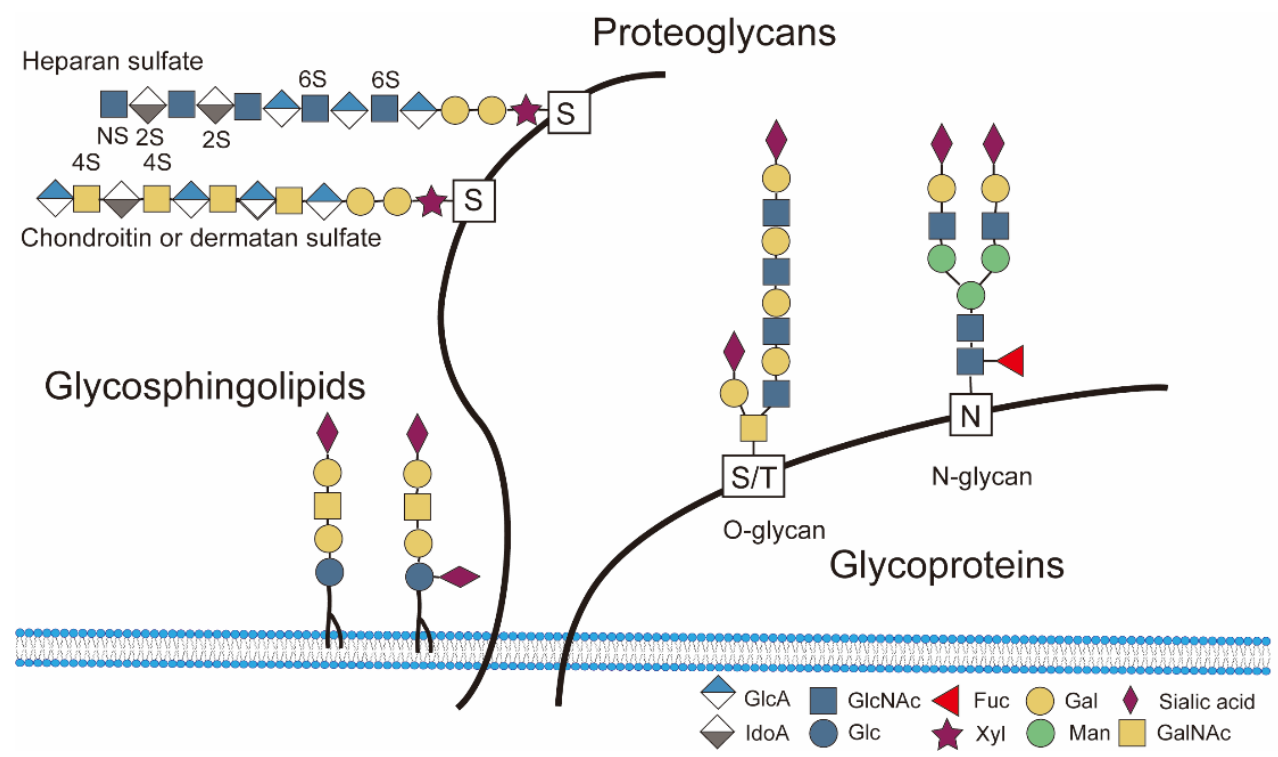

Figure 2. Major types of glycans on the human cell surface. Modified from [16].

\section{Glycan synthesis}

Contrary to proteins and nucleic acids, glycans are assembled in a non-templatedriven assembly process, catalyzed by more than 200 glycosyltransferases (GTs) [18]. In glycan syntheses, glycans are passed through an ER-Golgi pathway. First, monosaccharides are activated to different nucleotide sugar donors, including guanosine diphosphate (GDP), uridine diphosphate (UDP), thymidine diphosphate (TDP), or cytidine monophosphate (CMP) [19]. Next, these activated nucleotides are used as donors for glycosyltransferases (GTs) that covalently attach the sugar moiety to proteins, lipids, or glycan substrates. The GTs and the modification pathways are distinct for different glycans. For example, N-linked glycans are preassembled before being transferred to proteins, while glycosylation in O-linked glycans and glycolipids are stepwise assembled in both ER and Golgi [20, 21]. 


\section{Biological functions}

As complex macromolecules on the outer cell surface, glycans contribute to numerous biological functions. First of all, glycans have several stabilizing and protective barrier functions [10]. As is well known, glycans enfold cells and form a substantial protective physical barrier. Glycans also act as specific recognition sites for many other biomolecules, most commonly intrinsic and extrinsic glycan-binding proteins (GBPs). Intrinsic GBPs are typically involved in cell-cell interactions as well as recognition of extracellular molecules, whereas extrinsic GBPs usually comprise pathogenic microbial agglutinins, adhesins, or toxins. For instance, influenza virus infections are initiated by hemagglutinin binding to SA on the target cell surface [22]. Moreover, pathogens can rely on molecular mimicry of host glycans to escape from the immune response [23].

\section{Glycans and related diseases}

Glycosylation patterns are modified in numerous diseases, including congenital disorders of glycosylation (CDG), chronic inflammatory disease, and cancer. CDG is caused by genetic defects and/or changes in glycan synthesis or modification pathways, resulting in abnormal glycosylation of proteins and lipids [24]. Incidences of CDG disorders have steadily increased over the last decades and more than 125 genetic disorders have been identified so far across different kinds of glycosylation pathways $[9,25]$. In addition, glycosylation alterations can regulate and promote malignant transformations and tumor progression [26]. Occurring on the cell surface, alterations such as branched and core fucosed N-glycans, truncated Oglycans, increased and altered SA expression on terminal glycans, are important cancer biomarkers $[27,28]$.

\section{Sialic acids}

Sialic acids (SAs) are a class of monosaccharides with nine-carbon backbones [29, 30]. They are widely distributed on vertebrate cells and commonly decorate the terminal of the glycan chains [30,31]. By virtue of their negative charge, SAs are involved in ion binding and transport. Besides, SAs could serve as binding sites for many proteins, both from pathogens and host cells. Drawing on the SAs patterns, the 
host immune system can distinguish non-self from self. Interestingly, some pathogens can scavenge SAs from host cell glycans and decorate their own surface to assist the evasion of the host immune system [32].

Therefore, SAs are vital for host-pathogens interactions. During the process of evolution, hosts and pathogens have conducted an antagonistic evolutionary "arms race", where vertebrate cells constantly keep changing the structure of SAs to disable the rapidly evolving pathogens, which could either bind to host SAs or rely on mimicry. This may explain that SAs are among the most rapidly evolving glycan components and have the most diverse modifications and structures, exceeding other common monosaccharides [33].

\section{Diversity of sialic acids}

Up to now, the diverse SA family contain more than 50 distinct molecules [34]. Neu5Ac is the most common structure of SAs, and it is believed to be the precursor of other family members in the biosynthetic pathway. In addition to Neu5Ac, there are three other common SA "core" molecules, i.e., Neu5Gc, Neu, and deaminated neuraminic acid (KDN) (Figure 3) [29, 35]. Other SA molecules are generated by complementing one or several hydroxyl groups at C-4, C-7, C-8, and C-9 of the four "core" structures with O-sulphate, O-lactyl group, O-methyl, O-acetyl, or Ophosphate $[29,35]$. In the interaction between SAs and its receptors, each of the functional groups attached to the carbon backbone can participate in the specific binding. For instance, the hydroxyl groups of Neu5Ac at C-4, C-7, C-8, and C-9 provide opportunities for hydrogen bond-formation, and the $\mathrm{N}$-acetyl group contributes to the formation of hydrophobic interactions. These various modifications make SA molecules well suited to carry information for recognition and binding purposes. 


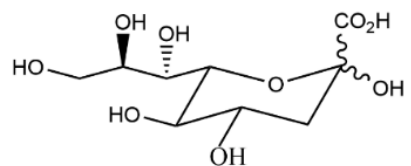

2-Keto-3-deoxynononic acid (Kdn)<smiles>CC(=O)NC1C(O)CC(O)(O)O[C@@H]1[C@H](O)[C@H](O)CO</smiles>

$N$-Acetylneuraminic acid (Neu5Ac)

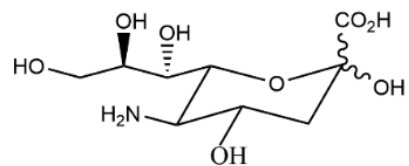

Neuraminic (Neu)

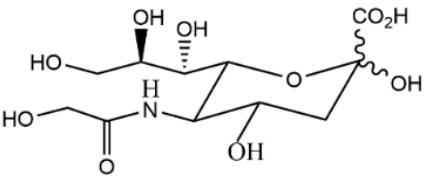

$N$-Glycolylneuraminic acid (Neu5Gc)

Figure 3. The core structures of SAs [36].

The diversity of SAs also derives from their different linkage to the underlying glycans. Typically, they can link to the C-6 position of GalNAc, C-6 or C-3 positions of Gal, or the C-8 or C-9 positions of other SAs (Figure 4) [29, 37]. These different linkages are catalyzed by more than 20 different sialyltransferases (STs) by adding nucleotide sugar CMP-SA to the underlying glycans [37-39]. These different linkages can also provide various binding sites for SA-specific binding proteins, for instance, the bird influenza viral hemagglutinin preferentially binds to the $\alpha 2,3$ linkage in SAs, while the human influenza virus has a preference for the $\alpha 2,6$ linkage in SAs [29].

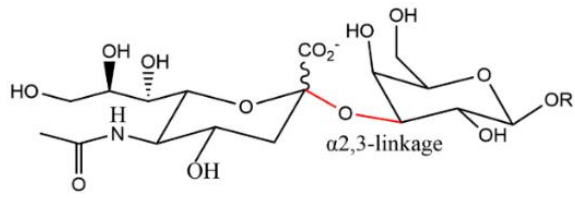

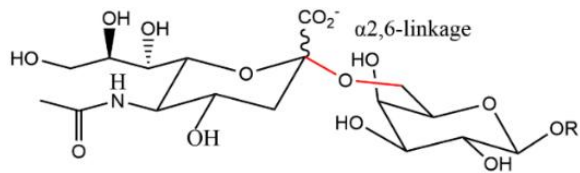

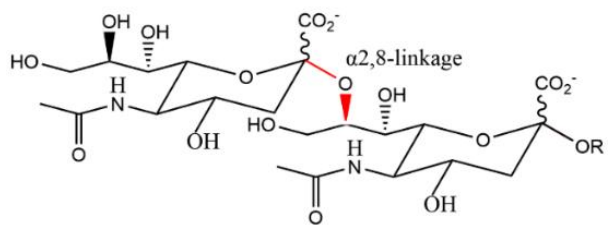

Figure 4. Common SA linkages to the underlying glycans [29]. 


\section{Sialic acids and cancer}

SAs are synthesized and expressed in most vertebrate cells. Cancer cells have been reported to have aberrant SA expression on their membrane glycoproteins, glycolipids, and glycoproteins secreted into the microenvironment [40, 41]. To date, mainly three reasons have been reported for hypersialylation [42]. The first reason is the overexpression and/or changed activity of STs involved directly in SA synthesis resulting in changed sialylation pattern [43, 44]. Secondly, the metabolic flux through the SA synthesis pathway can also affect SA expression. Almaraz et al. found that cellular glycoprotein sialylation increased significantly when adding SA precursors to cells in vitro [45]. Altered expression of endogenous neuraminidases (sialidases) is the third reason. Neuraminidases, in contrast to sialyltransferases, cleave SAs from glycans and thus regulate the SA expression [46].

Abnormal glycan expression has a vital role in promoting tumorigenesis. Cancer includes uncontrolled cell growth and resistance to programmed cell death and apoptosis [47]. Overexpression of ST6Gal I has been shown to hinder Fas-induced apoptosis, whereas silencing of the ST6Gal I gene enhanced Fas ligand-mediated apoptosis [48]. Hypersialylation could also increase critical cancer attributes such as metastasis and invasion capacities of tumor cells, resulting in the eventual demise of cancer patients. The function of ST3Gal I in ovarian cancer was studied and overexpression was found to increase the cell growth, metastasis, and invasion [49]. In addition, sialoglycans could help forming barriers around cancer cells to effectively resist cancer therapy. Cisplatin is a frontline chemotherapeutic for ovarian cancer, and Schultz and colleagues found that ST6Gal I is highly expressed in cells that show resistance to cisplatin and that non-resistant cells have lower expression of the enzyme [50]. The aberrant SAs structures, including the STn, $\mathrm{SLe}^{\mathrm{x}}$, and SLe ${ }^{\mathrm{a}}$ antigens, as well as expression of a non-human SA, Neu5Gc, which has been discontinued during human evolution, is suggested to be widely involved in tumorigenesis and promotion [51-57]. Hence, aberrant sialylation signals could be used as effective cancer biomarkers to help in cancer diagnosis. 


\section{Methods for studying sialic acids}

So far, many methods have been established for the studies of SAs. Among other monosaccharides, SAs have a relatively distinct molecular weight which could be detected by mass spectrometry [58]. However, this method suffers from drawbacks, such as expensive machinery and complex sample pre-treatment. Alternatively, SAbinding lectins can detect SAs and their linkage on the cell surface, as well as isolated sialoglycans. For instance, Maackia Amurensis Lectin (MAL) and Sambucus Nigra Lectin (SNA) can selectively conjugate to $\alpha 2,3$ and $\alpha 2,6$ linked SAs [59-61]. However, lectins can denature easily, and some of them have relatively low affinity and specificity [62].

Recently, several new SA labeling approaches have been established. Pamela et al. developed a cellular metabolic labeling approach to label sialic acid with its precursor analogue containing a biorthogonal functional group, including an azide or alkyne, which could be subsequently recognized and conjugated with a fluorescent probe or affinity tag through click chemistry [63]. This method has been successfully applied in cultured cells and living organisms. An alternative approach called chemoenzymatic labeling uses glycosyltransferase to add a biorthogonal group labeled nucleotide sugar donor to the recognized glycan receptor $[64,65]$.

\section{Molecularly imprinted polymers}

Molecular recognition plays an essential role in many biological processes [62]. There are many natural receptors involved in a biological system, including antibodies, which could recognize a range of both endogenous and foreign molecules. These biological molecules are however marked with several disadvantages, such as limited sensitivity and varying stability in complex environmental conditions. To overcome these drawbacks, one possible solution is to use molecularly imprinted polymers (MIPs). MIPs are polymers that have been processed using the molecular imprinting technique, creating template-shaped cavities in a polymer matrix $[62,66,67]$. Hence, the size and shape of the bespoke cavity is well fitted to the template molecule, much like the " lock and key " mechanism [68]. 
Although the term "imprinted polymer" was not coined until 1984, the technique could be tracked back to a study by Dickey in 1949 [69]. Dickey prepared silica adsorbents with specific affinities for organic dyes when the adsorbents were prepared in the presence of template dyes. Inspired by a mechanism proposed by Pauling [70], he realized that the mechanism is the same as the generation of antibodies, using the antigen molecule as template. Therefore, MIPs are also known as "plastic antibodies". In 1972, Wulff used organic polymers to produce molecular binding site and found that it is possible to introduce functional groups through covalent interaction, however, Mosbach established the method to produce imprinted cavities using a non-covalent approach [71-73]. After that, the imprinting technique developed rapidly, and the application of which has been extended to different areas.

\section{MIP synthesis}

Up to now, multiple methods have been reported for MIP synthesis, however, most of them follow a similar outline. Figure 5 illustrates the basic steps for MIP syntheses. First of all, several functional monomers that could conjugate with the template molecule covalently or non-covalently are chosen, and a mixture containing template molecules and functional monomers is prepared. After that, polymerization is initiated, to form a stabilized polymer matrix around the template. By removing the template molecule from the polymer matrix through washing steps, the template-specific cavities are formed, which could recognize and capture the target molecules. 




Figure 5. Schematic representation of the principles of MIP synthesis. Modified from [74].

In MIP synthesis, polymerization is a crucial step, and it can directly affect the MIP properties. In the past few decades, many different polymerization methods have been applied to MIP synthesis, including bulk polymerization [75], suspension polymerization [76], precipitation polymerization [77], and reversible addition fragmentation chain transfer [78]. Table 1 presents an overview of different polymerization techniques used in MIP syntheses. However, some methods still face drawbacks and need further improvement. For instance, some specific cavities produced from bulk polymerization are in the inner part of the polymers which are not easy to access. This could be solved by synthesis of a thin imprinted polymer shell on the surface of non-porous particles, which would expose more imprinted cavities on the surface. Besides, these core-shell MIPs could also benefit from the merits shared by the core particles, such as magnetic $\mathrm{Fe}_{3} \mathrm{O}_{4}$ nanoparticles [79, 80], activated silica gel [81], quantum dots (QDs) [82] and carbon QDs [83]. 
Table 1. Overview of polymerization techniques

\begin{tabular}{|c|c|c|}
\hline Imprinting methods & Example of template & Ref. \\
\hline Bulk polymerization & Iridoid glycosides, spiramycin & {$[84,85]$} \\
\hline Suspension polymerization & Malachite green, timolol & {$[86,87]$} \\
\hline Emulsion polymerization & Quercetin, Cd(II) & {$[88,89]$} \\
\hline Seed polymerization & Nicotinamide, promazine derivates & {$[90,91]$} \\
\hline Precipitation polymerization & Strychnine, vitamin E & {$[92,93]$} \\
\hline RAFT polymerization & SA, benzimidazole & {$[81,94]$} \\
\hline Sol-gel & Iprodione, methylxanthines & {$[95,96]$} \\
\hline
\end{tabular}

Because of the high importance of glycans, recently an increasing number of MIPs have been synthesized by using glycans as templates [81, 97, 98]. Among these studies, boronates have been extensively used as effective functional monomers for monosaccharide, glycan, and glycoprotein recognition. Regarding boronate affinity, boronic acids could effectively conjugate with cis-diol-containing compounds, forming stable five or six-membered cyclic esters at high $\mathrm{pH}$; the stable ester reversibly dissociates when the environmental $\mathrm{pH}$ drops to acidic [99]. Therefore, boronic acid related imprinting has become a key method for glycan analysis.

\section{Merits of MIPs}

Due to their special recognition properties, MIPs are known as "plastic antibodies". Compared to traditional antibodies, MIPs have several advantages. First, molecular imprinting is a versatile method and it has been applied to recognize a large variety of molecules, including metal [100], peptide [101] [102], protein [103], glycan [104], and viral targets [105]. Secondly, the MIPs synthesis procedure is controllable. This means that the different synthesis conditions, including functional monomers, polymerization methods, solvents, could be tested and optimized to achieve higher specificity and affinity for the target molecule. Thus, choosing an appropriate set of conditions significantly affects the template recognition properties. Besides, being of non-biological origin, synthesized MIPs are extremely robust and able to resist denaturing solvents and harsh condition. Hence, MIPs have extensive shelf-life, i.e., MIPs can be stored for years, and can be useful in a broader area of applications in complex and harsh settings. Furthermore, MIPs also represent 
one of the most straightforward, scalable, and cost-effective approaches to synthesize materials with tailored recognition sites [106].

\section{Application of MIPs}

In the early days, MIPs were mainly applied to separation rather than recognition. This occurs because of the unavoidable interaction between the template and the polymer/functional monomers. With the development of imprinting techniques, MIPs has so far been widely used in many areas, including sensing, bioimaging, and drug delivery. Shinde et al. has successfully synthesized core-shell SA-MIPs which could recognize glycan motifs on cancer cells (Figure 6) [81]. By including the fluorescent reporter nitrobenzoxadiazole (NBD) into the polymer shell, these particles could work effectively to image SA on tumor cells. Canfarotta et al. have developed a drug payload MIP, which could selective deliver cytotoxic doxorubicin to tumor cells that overexpress the epidermal growth factor receptor [107].

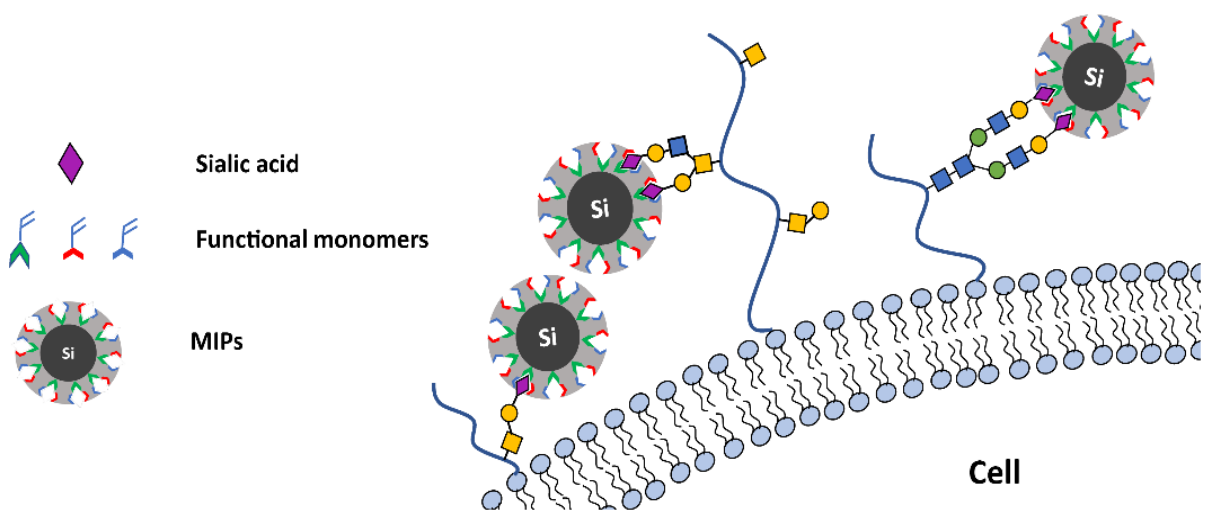

Figure 6. Core-shell SA-MIPs bound to SA on the cell surface. Modified from [81]. 


\section{Inflammation and cancer}

Inflammation and cancer are closely related and it has been reported that $90 \%$ of cancers are caused by somatic mutations and environmental factors, including inflammatory factors [108]. Inflammation is a primordial and well conserved biological response to harmful stimuli, such as pathogens, damaged cells, or irritants, and it is a protective response involving immune cells, molecular mediators, and blood vessels [109]. Cell proliferation and inflammation are enhanced during harmful stimuli associated with wounding, and subside when the stimulation is removed, or the repair is completed. In some circumstances the mechanism is disrupted, which will lead to chronic inflammation and abnormalities [109]. Even though it is clear that proliferation alone does not cause cancer, sustained cell proliferation in an environment abound with growth factors and inflammatory cells will promote the risk of cancer [110]. The cancer cells can physically damage the surrounding normal tissue and recruit immune cells to release inflammatory molecules, which could amplify the inflammation response [111]. Recent findings suggest that chronic inflammation could promote cancerogenesis and progression, and about $20 \%$ of cancers are initiated by chronic inflammation $[112,113]$.

\section{Cytokines}

Cytokines are secreted proteins released by a broad range of cells which regulate many different biological processes, including immunity, inflammation, cell proliferation, and differentiation [114, 115] (Figure 7). There are both antiinflammatory and pro-inflammatory cytokines. Pro-inflammatory cytokines are predominantly secreted by $\mathrm{T}$ helper cells and macrophages, and upregulate the inflammatory reaction [115]. Contrarily, anti-inflammatory cytokines control the response of pro-inflammatory cytokines by reducing inflammation and promoting healing [115]. Therefore, the balance between anti-inflammatory and proinflammatory cytokines is crucial to maintain health, and an excess of inflammatory cytokines and chronic inflammation contribute to inflammatory diseases, such as atherosclerosis and cancer $[116,117]$. 


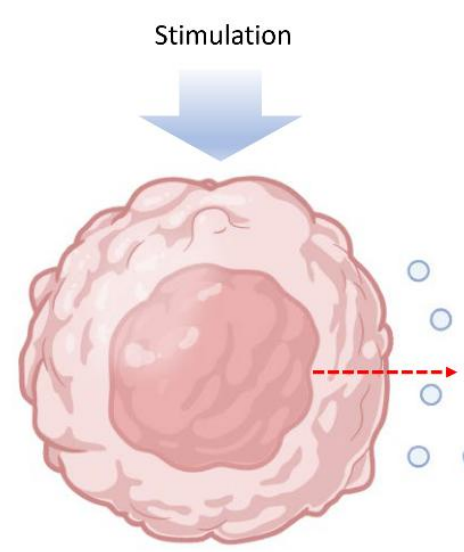

Cytokine Producing Cell

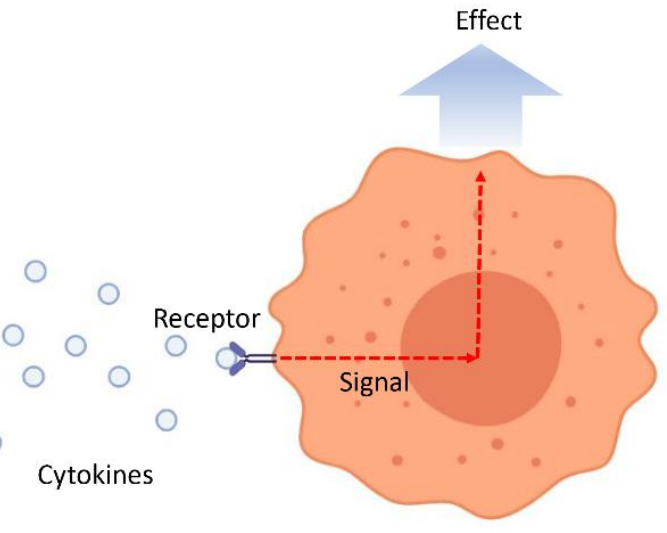

Target Cell

Figure 7. Schematic showing the biological regulation processes by cytokines.

\section{SARS-COV-2}

Coronaviruses belong to a large family of RNA viruses, which can infect a wide variety of animals [118]. Human coronaviruses (HCoVs) were first identified in the middle of 1960s [119]. Although these viruses have been identified and known for decades, they were considered to be relatively harmless, and their clinical importance and epidemic possibilities were not recognized until the outbreak of severe acute respiratory syndrome-CoV (SARS-CoV) and Middle East respiratory syndrome-CoV (MERS-CoV). The SARS epidemic occurred in 2002 and more than 8000 people were infected, resulting in 774 deaths [120]. A decade later, more than 2000 cases of MERS-CoV were confirmed, with 886 deaths from 2012 to 2021 (WHO) [121].

In December 2019, COVID-19 caused by a new coronavirus named severe acute respiratory syndrome coronavirus 2 (SARS-CoV-2) suddenly occurred and rapidly spread all over the world resulting in a pandemic $[122,123]$. As a new member of the coronavirus group, its genome is very similar to the bat coronavirus BatCoV RaTG13 and SARS-CoV [122, 124]. Compared with SARS-CoV, SARS-COV-2 is more readily transmitted from human to human. The virus could spread through 
direct or indirect contact with infected people, airborne and fomite transmission [125]. According to WHO, on the 21st of September 2021, more than 228 million cases have been confirmed globally, leading to about 4.7 million deaths [126]. The virus can cause a variety of symptoms, from mild cough and fever, to breathing difficulties, acute respiratory distress, and death [127, 128]. For elderly patients and people with chronic underlying diseases, SARS-CoV-2 usually triggers severe disease, causing massive hospitalization rates and high fatality rates [129].

\section{SARS-CoV-2 S protein}

The SARS-CoV-2 genome contains four structural proteins: S (spike), E (envelope), $\mathrm{M}$ (membrane) and $\mathrm{N}$ (nucleocapsid) proteins [130]. The $\mathrm{N}$ protein binds to the RNA and the other three proteins together create the viral envelope [130]. Among them, the $\mathrm{S}$ protein plays crucial roles in infection, recognizing receptors on the potential host cell surface and mediate membrane fusion and the viral entry process. Based on extensive studies using cryo-electron microscopy, it has been shown that the spike protein is a protein with homo-trimeric structure [131]. It is protruding from the viral surface and is mainly comprised of two functional subunits, responsible for the host cell receptor binding (S1 subunit) and the viral/cellular membranes fusion process (S2 subunit) (Figure 8). The distal S1 subunit contains the receptor-binding domain (RBD, 319-541 residues) which contributes to the host cell receptor recognition and stabilization of the prefusion process [132, 133]. Before the fusion and the entry process, the $\mathrm{S}$ protein normally exists in a metastable conformation. Once the $\mathrm{S}$ protein interacts with the receptor on the host cell, a structural rearrangement occurs and host cell proteases activate the $S$ protein by cleaving it into the S1 and S2 subunits, triggering the membrane fusion process between the virus and host cells [134]. 


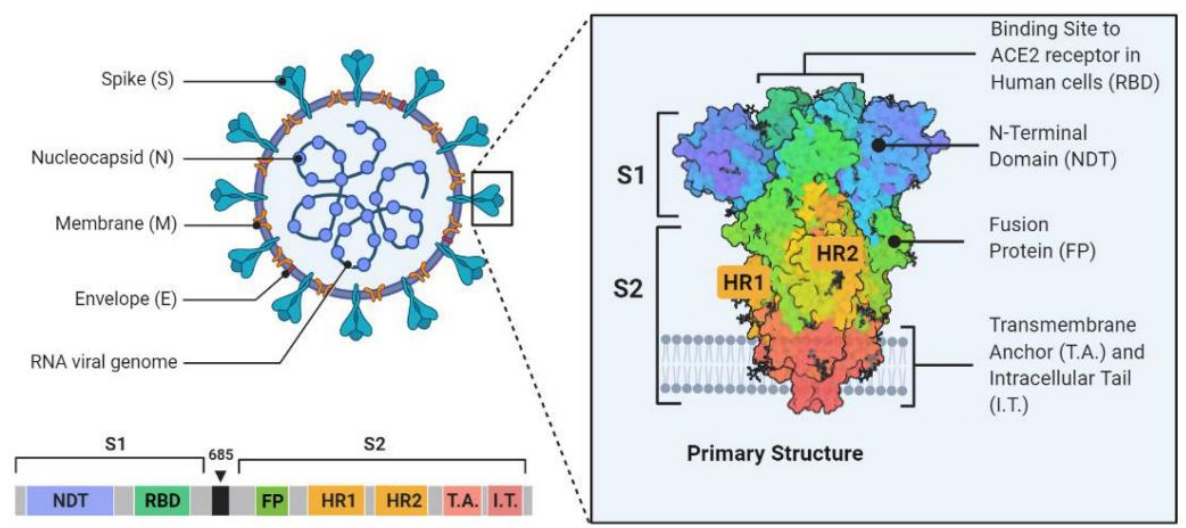

Figure 8. Overview of the structure of SARS-CoV-2 and the spike protein. Created from BioRender.com.

\section{Angiotensin-converting enzyme 2 (ACE2) receptor}

Similarly to SARS-CoV, the angiotensin-converting enzyme 2 (ACE2) has been identified as a receptor for SARS-CoV-2 in host cells [123, 132, 135]. ACE2 is a homologue of ACE and plays crucial roles in the renin-angiotensin system (RAS) which regulates blood pressure and electrolyte homeostasis. ACE2 is a counterregulatory enzyme to ACE. It catalyzes the hydrolysis of Ang II into Ang-(1-7), which could exert vasodilating, anti-fibrotic, and anti-inflammatory effects [136, 137]. Therefore, ACE2 is widely expressed in a variety of tissues, including the lung, kidney, and gastrointestinal tract. Consequently, the initial SARS-CoV-2 infection event mainly occurs in the (upper) respiratory tract [138].

\section{TMPRSS2 and other co-factors}

The SARS-CoV-2 viral interaction and subsequent infection not only depends on the host cell surface receptor ACE2, in addition, the entry process requires $S$ protein priming by a cellular host protease, i.e., transmembrane serine protease 2 (TMPRSS2) [120]. The protease TMPRSS2 can activate the viral S protein by cleavage at the $\mathrm{S} 1 / \mathrm{S} 2$ site. Subsequently, the viral fusion process starts, a process driven by the S2 subunit [139]. Similar with SARS-CoV, SARS-CoV-2 also uses 
TMPRSS2 for S protein priming [140]. To verify this, Hoffmann et al. used a TMPRSS2 inhibitor, camostat mesylate, to effectively block lung cell infection by SARS-CoV-2 and SARS-CoV [120].

Besides TMPRSS2, other factors may affect the infection process. Glycans are important candidates since they fence the cells, and a virus must pass through the glycans to engage receptors and initiate the infection process. Indeed, many viruses use glycans as co-receptors [141, 142]. Recently, heparan sulfate has been reported to be a co-receptor of the SARS-CoV-2 S protein. It could interact with $S$ protein independently and also promote the spike-ACE2 interaction [143]. It has also been reported that MERS-CoV infect host cell through sialylated receptors [144, 145]. Although the SARS-CoV-2 S protein shares some similarity with MERS-CoV, it is still unclear if SAs have been employed as a co-receptor for SARS-CoV-2. Therefore, the roles of SAs in SARS-CoV-2 interaction and infection need to be evaluated. 


\section{METHODS}

\section{Cell lines}

The cell lines COLO 205, A549, RAW 264.7, Jurkat, MCF7, CAMA-1, MDA-MB468, MDA-MB-231, HaCaT, Vero E6, Hs 578T, SK-BR-3, PC-3, Calu-3, Hep G2, Caco-2, THP-1, T-47D, A-431 and SW48 were obtained from American Type Culture Collection (ATCC) (Manassas, VA, US). HEK-n cells were purchased from Thermo Fisher Scientific (Waltham, MA, US). COLO 205 cells were cultured in RPMI-1640 medium (Thermo Fisher Scientific, MA, US) supplemented with $10 \%$ fetal bovine serum (FBS). A549 and RAW 264.7 cells were cultured in RPMI-1640 medium supplemented with $10 \% \mathrm{FBS}$ and $1 \%$ penicillin streptomycin (PEST). Jurkat and MCF7 cells were cultured in RPMI-1640 medium supplemented with 10 $\%$ FBS and $50 \mu \mathrm{g} / \mathrm{mL}$ gentamycin. CAMA-1 cells were cultured in RPMI-1640 medium supplemented with $10 \% \mathrm{FBS}, 1 \%$ PEST and $1 \%$ sodium pyruvate. MDAMB-468, MDA-MB-231 and HaCaT were cultured in DMEM medium (Thermo Fisher Scientific, MA, US) supplemented with 10\% FBS. Vero E6 were cultured in DMEM supplemented with $10 \%$ FBS and $2 \mathrm{mM} \mathrm{L-Glutamine.} \mathrm{Hs} \mathrm{578T} \mathrm{cells} \mathrm{was}$ cultured in DMEM supplemented with $10 \%$ FBS, $1 \%$ PEST, and $10 \mu \mathrm{g} / \mathrm{mL}$ insulin (Sigma-Aldrich, St Louis, MO, US). SK-BR-3 and PC-3 were cultured in DMEM supplemented with 10\% FBS, 1\% GlutaMAX (Life Technologies) and 1\% PEST. Calu-3 and Hep G2 cells were cultured in MEM medium (Thermo Fisher Scientific, MA, US) supplemented with $10 \%$ FBS. Caco-2 cells were cultured in MEM medium supplemented with $20 \%$ FBS, $1 \%$ PEST, $1 \%$ NEAA, and $1 \%$ L-Glutamine. THP-1, T-47D, A-431 were cultured in Eagle's Minimum Essential medium (EMEM, Sigma-Aldrich, St Louis, US) supplemented with $10 \% \mathrm{FBS}, 1 \%$ LGlutamine and $1 \%$ non-essential amino acids, NEAA. SW48 cells were cultured in Leibovitz's L-15 medium (Thermo Fisher Scientific, MA, US) supplemented with 
10\% FBS. HEK-n cells were maintained in EpiLife growth medium (Thermo Fisher Scientific, MA, US) with $60 \mathrm{mM}$ calcium chloride supplemented with $1 \%$ of human keratinocyte growth supplement (HKGS) and $0.2 \%$ gentamycin/amphotericin. All the cell lines were cultured at $37^{\circ} \mathrm{C}$ with $5 \% \mathrm{CO}_{2}$ in $100 \%$ relative humidity $(\mathrm{RH})$.

\section{Flow cytometry analysis}

\section{Lectin staining (Paper I-IV)}

The expression of SA was investigated through flow cytometry by using SA specific lectins. $0.5 \times 10^{6}$ cells were harvested and washed twice with PBS, followed by incubation with biotin-labeled MAL I or SNA (Vector Laboratories, Burlingame, $\mathrm{CA}, \mathrm{UA}$ ) at $4{ }^{\circ} \mathrm{C}$ for $30 \mathrm{~min}$. After washing twice with PBS, the cells were incubated with streptavidin-FITC (Sigma-Aldrich, St Louis, MO, US) in the dark at $4{ }^{\circ} \mathrm{C}$ for $20 \mathrm{~min}$. The samples were again washed twice with PBS and resuspended in $300 \mu \mathrm{L}$ PBS. Samples with secondary antibody alone were used as negative controls. The flow cytometric analysis was carried out on the BD Biosciences, Accuri C6 Flow Cytometer (NJ, US) with a $488 \mathrm{~nm}$ excitation laser coupled to a 530/30 nm BP filter.

\section{SA-MIP staining (Paper I-III)}

To test the binding between SA-MIPs and cancer cells, $1 \times 10^{6}$ cells per sample were stained with SA-MIPs. The cells were washed twice with PBS and thereafter incubated with SA-MIPs $(0.1 \mathrm{mg} / \mathrm{mL})$ at $4{ }^{\circ} \mathrm{C}$ for $30 \mathrm{~min}$ in the dark. After incubation, the samples were washed twice with PBS and further resuspended in 300 $\mu \mathrm{L}$ PBS for flow cytometric analysis.

\section{Pre-treatment of SA-MIPs with SA conjugates (Paper I, III)}

In this assay, the SA-MIPs were pre-treated with pentavalent SA conjugates before they were used for MIP staining. Pre-treatment was carried out by pre-incubating the MIPs solution with different concentrations $(20$ and $200 \mu \mathrm{M})$ of the SA conjugates, including ME0752, ME0970, ME0976 or ME1057, at room temperature (RT) for 5 min. Then, the pre-treated SA-MIPs were used for cell staining according to the experimental procedure described above. 
Neuraminidase treatment (Paper IV)

The cells were washed twice with PBS and fixed with $4 \%$ formaldehyde at RT for 10 min. After washing twice with PBS ( $1 \%$ BSA), $5 \times 10^{5}$ cells were treated with 0.2 $\mathrm{U} / \mathrm{mL}$ neuraminidase (Sigma-Aldrich, St Louis, MO, US) at $37{ }^{\circ} \mathrm{C}$ for $90 \mathrm{~min}$ and untreated cells were used as control. Then the cells were washed twice with PBS and used for lectin staining as described above.

\section{ACE2 and TMPRSS2 staining (Paper IV)}

The cells were harvested and washed twice with PBS and then fixed with $4 \%$ formaldehyde at RT for $10 \mathrm{~min}$. After two washes with PBS ( $1 \%$ BSA), $5 \times 10^{5}$ cells were stained with anti-ACE2 antibody $(5 \mu \mathrm{g} / \mathrm{mL}, \mathrm{R} \& \mathrm{D}$ system, Minneapolis, MN, US), goat isotype control ( $5 \mu \mathrm{g} / \mathrm{mL}, \mathrm{R} \& \mathrm{D}$ system), anti-TMPRSS2 antibody (26 $\mu \mathrm{g} / \mathrm{mL}$ Thermo Fisher Scientific, Waltham, MA, US) or RBD-Fc $(10 \mu \mathrm{g} / \mathrm{mL}, \mathrm{R} \& \mathrm{D}$ system) in the dark at RT for 30 min with a total volume of $100 \mu \mathrm{L}$, respectively. After incubation, the samples were washed twice with PBS (1\% BSA) followed by staining with the corresponding secondary antibody (FITC labeled, R\&D Systems) in the dark at RT for 30 min. Samples with secondary antibody alone were used as controls. After incubation, the cells were washed twice with PBS (1\% BSA) and resuspended in $300 \mu \mathrm{L}$ PBS for flow cytometer analysis.

\section{Fluorescence microscopy (Paper I-II)}

To analyze the SA expression on different cancer cells, the cells were stained with the lectins (MAL I and SNA) and SA-MIPS, respectively, and analyzed by confocal fluorescence microscope. In this study, $1 \times 10^{5}$ cells/well were first seeded in a Falcon multi-chamber culture glass slide and incubated for $48 \mathrm{~h}$ at $37{ }^{\circ} \mathrm{C}$ with $5 \% \mathrm{CO}_{2}$ in $100 \%$ RH. After incubation, the cells were washed twice with PBS and fixed with 4 $\%$ formaldehyde at RT for 10 min followed by washing twice with PBS and once with PBS-Triton (0.05\% Triton X-100 in PBS). These cells were permeabilized and stained with rhodamine phalloidin for $30 \mathrm{~min}$ at RT. After washing twice with PBSTriton and twice with PBS, the samples were incubated with $100 \mu \mathrm{L}$ SA-MIPs $(0.1$ $\mathrm{mg} / \mathrm{ml}$ ) or biotinylated MAL I and SNA for $30 \mathrm{~min}$ at RT. The sample stained with biotinylated lectins was incubated with streptavidin-FITC, washed with PBS, and 
further stained with DAPI for 4 min at RT. The cells were mounted with ProlongQR Gold antifade mounting medium and analyzed using confocal fluorescence microscopy (Nikon Instruments A1R HD25, Melville, NY, US).

\section{Stimulation of Jurkat cells (Paper III)}

In order to mimic the inflammatory environment, $\mathrm{T}$ leukemia Jurkat cells were stimulated to produce different cytokines. In this assay, $5 \times 10^{6}$ Jurkat cells were stimulated in $5 \mathrm{~mL}$ complete RPMI-1640 medium (supplemented with $10 \%$ FBS and $50 \mu \mathrm{g} / \mathrm{mL}$ gentamycin) with addition of PHA $(10 \mu \mathrm{g} / \mathrm{mL})$ for $72 \mathrm{~h}$. After stimulation, the cells were centrifuged at $300 \times \mathrm{g}$ for $10 \mathrm{~min}$ and the supernatant was collected and kept at $4{ }^{\circ} \mathrm{C}$ for further use.

\section{ELISA analysis for IL-2, IL-6, IL-8 and TNF- $\alpha$ (Paper III)}

To determine the cytokine content in the stimulated Jurkat cell medium, ELISA were performed using Quantikine ELISA Kits (R\&D Systems, Minneapolis, MN, US), according to the manufacturer's instructions. Briefly, ELISA plates were coated overnight with diluted capture antibodies against TNF- $\alpha$, IL-2, IL-6, or IL-8, respectively. The plates were washed three times with PBS-T (PBS with $0.05 \%$ Tween-20) and blocked by PBS (1\% BSA) at RT for $1 \mathrm{~h}$. Next, the plates were washed three times with PBS-T and incubated with TNF- $\alpha$, IL-2, IL-6, or IL-8 recombinant standards and Jurkat cell supernatant, respectively, at RT for $2 \mathrm{~h}$. After that, the plates were again washed three times with PBS-T and incubated with 50 $\mathrm{ng} / \mathrm{mL}$ biotin-linked detection antibodies at RT for $2 \mathrm{~h}$. After three washes with PBS-T, the plates were incubated with streptavidin-HRP at RT for $20 \mathrm{~min}$. Then the plates were washed three times with PBS-T and incubated with substrate solution (1:1 mixture of $\mathrm{H}_{2} \mathrm{O}_{2}$ and tetramethylbenzidine, TMB) at RT for $20 \mathrm{~min}$. After that, $100 \mu \mathrm{L} /$ well of stop solution was added and the absorption was analyzed with a microplate reader at $450 \mathrm{~nm}$. 


\section{Quantitative reverse transcription PCR (Paper IV)}

In this study, quantitative reverse transcription PCR (RT-qPCR was used to analyze the ACE2 and TMPRSS2 mRNA expression. Firstly, the total RNA was extracted from $5 \times 10^{5}$ cells through RNeasy Mini Kit (Qiagen, Hilden, DE). Then the total RNA was reverse transcribed to cDNA using SensiFAST cDNA Synthesis Kit (Bioline, Cincinnati, OH, US) according to the manufacturer's instructions. The mRNA expression levels of ACE2 and TMPRSS2 were quantified using q-PCR analysis with SensiFAST SYBR No-ROX Kit (Bioline). The samples were run and analyzed on a Light Cycler 480 II real time PCR system and the PCR products were further analyzed by agarose gel electrophoresis. In this assay, $\beta$-actin (human $A C T B$ ) was used as a reference gene and the sequences of the specific primers are shown in Table 2.

Table 2. The sequence of the primers for q-PCR.

\begin{tabular}{|c|c|c|c|}
\hline Genes & Primers & Sequence $\left(5^{\prime}>3^{\prime}\right)$ & Reference \\
\hline \multirow{2}{*}{ ACE2 } & $\begin{array}{l}\text { forward } \\
\text { primer }\end{array}$ & $\begin{array}{l}\text { GGGATCAGAGATCGGAAGAAGAA } \\
\text { A }\end{array}$ & \multirow{2}{*}{$\begin{array}{l}\mathrm{NM}_{-} \\
021804\end{array}$} \\
\hline & $\begin{array}{l}\text { reverse } \\
\text { primer }\end{array}$ & AGGAGGTCTGAACATCATCAGTG & \\
\hline \multirow{2}{*}{ TMPRSS2 } & $\begin{array}{l}\text { forward } \\
\text { primer }\end{array}$ & AATCGGTGTGTTCGCCTCTAC & \multirow{2}{*}{$\begin{array}{l}\text { NM_ } \\
005656\end{array}$} \\
\hline & $\begin{array}{l}\text { reverse } \\
\text { primer }\end{array}$ & CGTAGTTCTCGTTCCAGTCGT & \\
\hline \multirow{2}{*}{ ACTB } & $\begin{array}{l}\text { forward } \\
\text { primer }\end{array}$ & CCCTGGACTTCGAGCAAGAG & \multirow{2}{*}{$\begin{array}{l}\text { NM_ } \\
001101\end{array}$} \\
\hline & $\begin{array}{l}\text { reverse } \\
\text { primer }\end{array}$ & ACTCCATGCCCAGGAAGGAA & \\
\hline
\end{tabular}




\section{RESULTS AND DISCUSSION}

\section{Sialic acid as a biomarker studied in breast cancer cell lines in vitro using fluorescent molecularly imprinted polymers (Paper I)}

Sialylation is one of the most important glycosylations and it has been reported that cancer cells usually have aberrant sialylations [29, 30]. Antibodies and lectins are commonly used for SA detection but these reagents face drawbacks, including high cost, limited storage stability, and intricate application conditions, which call for other tools for SA detection. We and other groups have recently presented a novel method for SA detection by using MIPs as SA receptors. The aim of this study was to further extend the application of the synthesized MIPs and monitor SA expression in a panel of breast cancer cell lines [81].

Breast cancer is highly heterogeneous, and can be classified in luminal A, luminal B, and basal-like subgroups [146]. Consequently, because of subgroup specific properties, the diagnostic and treatment methods for breast cancers are different. To reveal the SA expression in breast cancer cell lines, six breast cancer cell lines, including T-47D, MCF7, CAMA-1, MDA-MB-468, MDA-MB-231, and Hs 578T were stained with two lectins, MAL I and SNA, against $\alpha 2,3$ and $\alpha 2,6$ SA, respectively. Our results show that these cell lines have inconsistent $\alpha 2,3$ and $\alpha 2,6$ SA expression levels. For instance, T-47D cells express both $\alpha 2,3$ and $\alpha 2,6$ SA at relative high levels, whereas $\mathrm{Hs} 578 \mathrm{~T}$ cells mainly express $\alpha 2,3 \mathrm{SA}$. These differences may contribute to their highly heterogeneous properties in cancer metastasis and invasion. 
Following lectin binding, the binding of SA-MIPs to these breast cancer cell lines were tested. Hs 578T, MDA-MB-231, and MDA-MB-468 bound less SA-MIPs compared with T-47D and CAMA-1, while MCF 7 cells had the highest SA-MIPs binding capacity. However, it is hard to conclude if SA-MIPs have preference for $\alpha 2,3$ or $\alpha 2,6$ SA, since generic SA was used as a template for SA-MIPs synthesis. To further investigate whether the two well-known cancer biomarkers, i.e., epithelial cell adhesion molecule (EpCAM) and CD44, had any correlation in expression compared to SA, those biomarkers were analyzed by using flow cytometry [147, 148]. Our results show that low EpCAM expression levels correlated well with the SA-MIPs binding pattern, in contrast to the CD44 expression that showed inverse correlation.

The specificity of the SA-MIPs was tested using two pentavalent sialic acid conjugates ME0970 and ME1057. Initially, these SA conjugates were designed to be used for their inhibitory effect against viruses which utilize SA as receptors on host cell surfaces [149]. In this assay, SA-MIPs were preincubated with ME0970 or ME1057, respectively, before cell staining. Our results show that the binding of SAMIPs decreased by $66 \%$ and $64 \%$ when preincubating with SA conjugates ME0970 and ME1057, respectively, indicating the specificity of the MIPs. Further, we conclude that SA-MIPs are effective tools to detect SA on breast cancer cell lines.

\section{Improved biomarker detection analysis of glycosylated cell surface structures using sialic acid-targeted fluorescent core- shell particles (Paper II)}

The aim of the second study was to improve the properties of the SA-MIPs and apply them to detect SA on the surface of a larger set of different cancer cell lines. These novel SA-MIPs were synthesized on silica-coated polystyrene particles (ca. $170 \mathrm{~nm}$ ) [150], which are smaller compared to the previous SA-MIPs (ca. $200 \mathrm{~nm}$ ) [81], and therefore have higher surface-area-to-volume ratio for binding. Because of the lower density of the silica-coated polystyrene cores, these particles have improved suspensibility and show a lower tendency to sediment [150].

To evaluate the binding performance of the synthesized polystyrene MIPs, the SA expression on thirteen cancer cell lines (SK-BR-3, MDA-MB-468, PC-3, THP-1, Jurkat, A-431, MCF7, MDA-MB-231, A549, CAMA-1, T-47D, and Hs 578T) were first analyzed using the two lectins MAL I and SNA followed by SA-MIPs. Our 
results show that CAMA-1 and MCF7 have the lowest $\alpha 2,3$ and $\alpha 2,6$ expression, respectively. A549 was determined to have the highest $\alpha 2,6$ SA expression among these cell lines. Our results revealed that these cancer cell lines have varied expression of $\alpha 2,3$ and $\alpha 2,6 \mathrm{SA}$, and therefore display different binding patterns with SA-MIPs. These cell binding results were further compared with previous SA-MIPs. The results show that the novel SA-MIPs with silica-coated polystyrene cores have significantly higher ability to conjugate with cancer cells, tentatively owing to their smaller size and better suspensibility.

Furthermore, the specificity of the SA-MIPs was studied with an inhibition assay using another set of pentavalent SA conjugates ME0752 and ME0976 [149, 151]. SA-MIPs were separately pre-incubated with the derivates before cell staining and thereafter analyzed by flow cytometry and confocal microscopy. A clear reduction in SA-MIP binding to the cells was observed from the flow cytometry data, which confirms the specificity of the novel SA-MIPs. Confocal microscopy further revealed the SA-MIPs binding pattern on the cell surfaces and how SA conjugates affect SA-MIP binding. The microscopy images show that SA-MIPs attached to the cell membrane and SA-MIPs aggregation could be observed for the A549 and MCF7 sample. When SA-MIPs were pre-incubated with the SA conjugates, SA-MIP binding was attenuated, and the aggregate size was reduced. The latter may be due to inhibitors acting as spacer molecules between SA-MIP particles. To conclude, smaller size and improved suspensibility benefits the newly synthesized SA-MIPs since they show higher ability to conjugate with SA on cancer cells, showing potential for cancer diagnosis and analysis.

\section{Determination of cytokine regulated glycan expression by using molecularly imprinted polymers targeting sialic acid (Paper III)}

Fast-growing cancer cells could exhaust the nutrient supply and generate nutrient deprived necrotic cells at the tumor's core, releasing pro-inflammatory cytokines, including TNF- $\alpha$, IL-1b, IL-6, and IL-8 [152]. Well known tumor promoters, i.e. inflammation and cytokine production, modulate the cellular microenvironment and induce aberrant cell surface glycan patterns $[114,115]$. At the outermost position of the glycan chains, SA plays crucial roles in cancer cell proliferation, differentiation, and metastasis. In this study, we aimed to analyze the SA expression while 
mimicking the tumor microenvironment, and by determining the expression by the use of SA-MIPs.

To mimic the complex cytokine microenvironment, the leukemia cell line Jurkat was stimulated with phytohemagglutinine (PHA) to produce soluble cytokines. The cytokine composition was investigated with different ELISA kits, specific for IL-2, IL-6, IL- 8 , and TNF- $\alpha$, respectively. More than $400 \mathrm{pg} / \mathrm{mL}$ of IL- 8 was detected, whereas lower amounts of IL-2 and TNF- $\alpha$ were determined.

Two different cancer cell lines, MCF7 and RAW 264.7, were stimulated with the cytokine cocktail thus produced. The SA expression of MCF7 and RAW 264.7 cells was analyzed by flow cytometry using both lectins and the SA-MIPs. Interestingly, we found that both cell lines increased the SA expression after treatment with the cytokine cocktail; the increase was detected by both lectins and SA-MIPs. SA expression is closely associated with cell adhesion, migration, and invasion, giving this glycan a possible role in the inflammatory environment that may contribute to cancer metastasis $[153,154]$. In order to determine the influence of the candidate cytokine(s) on the increased SA expression, MCF7 and RAW 264.7 cells were stimulated with individual recombinant cytokines IL-4, IL-6, or IL-8. Our results show that SA expression was increased in RAW 264.7 by all cytokines, while no obvious change was observed for MCF7 cells. There could be two possible explanations: 1) there are other cytokines besides IL-4, IL-6 and IL-8 that may increase SA expression in MCF7 cells; 2) these cytokines may work cooperatively and therefore increase SA expression.

Based on these results, we conclude that an inflammatory tumor microenvironment and some pro-inflammatory cytokines could stimulate cells to increase SA expression, which could further promote cancer metastasis [108, 155]. Besides, SAMIPs can be used to detect the changes in SA expression after stimulation, demonstrating its potential to become an important tool in the investigation of overexpressed glycans in the tumor microenvironment.

\section{SARS-CoV-2 spike protein interaction with cell types from tissue susceptible to viral infection (Paper IV)}

According to the WHO, until the end of September 2021, about 228 million COVID-19 cases have been confirmed globally, causing more than 4 million deaths. 
It is becoming one of the most sever challenges faced by humanity. Understanding the viral binding and infection mechanisms is crucial for disease prevention and treatment. In this study, we aimed to investigate the interactions between the RBD in SARS-CoV-2, and a panel of human cell lines from tissues susceptible to viral infection, including lung, skin, liver, and colon. Occupying the outermost position of glycan chains, SAs are not only involved in cancer migration and invasion, but also play crucial roles in many pathogen infections. SAs have been reported to be related to coronavirus infections, therefore the interaction between human cells and the RBD receptor, ACE2, was investigated through removing SA from the cell surface using the enzyme neuraminidase [156].

ACE2 play crucial roles in the infection process [123, 132]. To evaluate the ACE2 expression, the cell lines A-431, Caco-2, Calu-3, COLO 205, HaCaT, SW48, A549, MCF7, Hep G2, and Vero E6 were stained with an ACE2 antibody and analyzed using flow cytometry. Our results show that the African green monkey epithelial kidney cell line Vero E6 and the liver cancer cell line HepG2 have higher ACE2 expression compared to the lung cancer cell line A549. Our results also showed that A-431 and Caco-2 have the lowest ACE2 expression among the cell lines studied. To further confirm these data, the specificity of the ACE2 antibody was verified using a control isotype specific goat antibody and a pre-adsorption assay.

After the ACE2 expression level evaluation, the binding between RBD and the ten cell lines from different tissues were tested. Interestingly, the colon cell line COLO 205 and Vero E6 had a high affinity for RBD. To further explore the RBD binding mechanism, the involvement of SA in this interaction has been evaluated. In this assay, the binding between RBD and cells were tested after SA was enzymically cleaved by neuraminidase. Indeed, no clear binding decrease was observed, which suggests that SA may not be a RBD receptor. These results are in line with the work of Yang el al., showing that sialic acids are not coreceptors of spike protein and may even shield virus/spike binding [157].

Although SA may not be the RBD receptor of SARS-CoV-2, it cannot be ignored that SA plays crucial roles in many biological processes and facilitates the initial interaction with many pathogens, including influenza virus, MERS and HCoVOC43 $[144,145]$. Due to its multifaceted interaction pattern, SA remains one of the most crucial, interesting, and mysterious molecules which need further studies. 


\section{CONCLUSIONS AND FUTURE PERSPECTIVES}

In this project, SA analysis and its relationship with both cancer and viral SARSCoV-2 interactions was explored. SA-MIPs are synthetic receptors used here as a robust alternative to lectins and antibodies. The aim of this study was to sensitively test and evaluate the SA content by using SA-MIPs and also apply the polymer particles for early-stage cancer diagnostics. Further, the aim was to investigate the possible role of SA in the interaction between the RBD of SARS-CoV-2 and the human receptor ACE2.

We have previously prepared the fluorophore NBD doped SA-MIPs using boronatebased imprinting techniques and applied it to cancer cell lines. The application of SA-MIPs was firstly expanded to a panel of breast cancer cell lines and the SA expression patterns were verified by lectins. The binding pattern of the SA-MIPs to the breast cancer cell lines was further compared with EpCAM and CD44 expression. These two markers are closely related to circulating tumor cells, showing an interesting correlation with the SA-MIP binding. Then, the SA-MIP synthesis was refined by using a smaller and lighter silica-coated polystyrene core, showing improved suspensibility and higher ability to bind with cancer cells. Furthermore, creating an inflammatory environment showed an increased sialyation detected by SA-MIPs, confirming its potential to become an important tool to investigate altered glycan expression in the tumor microenvironment. Moreover, the interaction between RBD and a panel of human cell lines from tissues susceptible to viral infection was investigated and the potential roles of several factors involved in this interaction was evaluated. 
The molecular imprinting techniques are moving forward, however, there are still questions unanswered, highlighting the need for further investigations. The specificity the target molecule, especially regarding glycan motifs, remains challenging, though many achievements have been made. The binding ability to the target molecule is also crucial and an example from the current work is the small size MIPs particles with superior suspensibility and more homogeneous antibodylike staining. Up to now, most of the current glycan imprinted polymers focused on monosaccharide recognition, however, the SA linkage and the structure of the underlying glycan are important for investigations and discrimination between normal and cancer cells. Synthesis of MIPs for SA with underlying glycan motif is still urgently needed.

Future work should include synthesis of SA-MIPs showing preference to the $\alpha 2,3$ or $\alpha 2,6 \mathrm{SA}$, which may help in cancer diagnostics and related biomarker discovery. To achieve desired MIP sizes, carbon nanodots (with an average diameter of less than $10 \mathrm{~nm}$ ) can be used as MIP cores. Other fluorophores, especially fluorophores with near-infrared emission can be used as MIP dopants, greatly benefitting MIP based in vivo imaging and analysis. Besides, other SA related biomarkers, e.g., the STn antigen, which is expressed abundantly by many tumors, will be the next generation SA-related antigen used as template for MIP synthesis.

In summary, this work takes a step further in SA research, which may contribute to the development of new tools for analysis of SA, SA-related cancer diagnosis and treatment, as well as tracking pathogen interactions with human cells. 


\section{ACKNOWLEDGEMENTS}

My $\mathrm{PhD}$ studies was an interesting and unforgettable journey in science, and it would not be possible without people's help and supporting. Here, I would like to express my gratitude to everyone who helped me during my $\mathrm{PhD}$ studies.

First of all, I would like to thank my main supervisor, Anette Gjörloff Wingren, for giving me the opportunity to participate this project. Thanks for encouraging and guiding me to stay on track. She is always patient and help me solve all the problems, both in life and science. Her wisdom, optimistic and enthusiastic attitude to science inspired me in future work.

I would also like to thank my co-supervisor Maria Magdalena Stollenwerk and Lars Ohlsson for their encouragement and constant support with giving instructive advice and sharing me all their knowledge and skills.

I would also like to thank my examiner Håkan Eriksson for his assistance with all $\mathrm{PhD}$ courses and sharing me his outstanding knowledge on flow cytometry and cell culture.

A big thanks to GlycoImaging partners, Knut Rurack and Kornelia Gawlitza (BAM) for their help and advice in MIPs synthesis. Jenny Persson (Umeå University) and Pirkko Härkönen (University of Turku) for their advices on experimental work and feedback on the manuscript. Kersti Alm (Phase Holographic Imaging) for her encouragement and sharing knowledge about holographic microscope. Henrik Clausen, Yang Zhang and Yoshiki Narimatsu from University of Copenhagen for providing gene engineered cell and insightful conversation in glycomics. Special thanks to Börje Sellergren for providing MIPs and sharing valuable information about MIPs. 
My warmest thanks to Zahra El-Schich for helping me with the project by sharing her knowledge about MIPs, cell culture and holographic microscope, and always giving useful suggestions. I would also like to thank Mikael Elofsson for providing us SA inhibitors and giving instructive advice. A big thanks to Nishtman Dizeyi for helping me with WB.

I would like to thank my collogues, Zoltan for language proofs, Anna for helping with ELISA, WB and nice presentation and discussion in group meeting. Thanks to Irene for ordering reagents, finding chemicals from KLARA and many other things occurred in lab. I would like to thank Lennart, Sergey, Petri, Tove, Eva and Magnus for enjoyable casual conversations. I would also like to thank groups and researchers in Forskaren for many nice meetings, and discussions there.

The fellows in glycoImaging, Tianyan, Louise, Alejandra, Martha, Shan, Richard, Andriana and Victor, thanks for communication, discussion and collaboration. We had many unforgettable journeys and a lot of fun together.

I am thankful to my present and former fellow researchers, Elena, Olga, Stefan and Mitra for enjoyable time in lunch, fika and after works.

I acknowledge European Union's Horizon 2020 research and innovation program under the Marie Sklodowska-Curie grant agreement (grant number 721297) to financial support during the PhD.

Finally, I would like to thank my family, especially my wife for unconditionally support. 


\section{REFERENCES}

1. Guan, X., Cancer metastases: challenges and opportunities. Acta pharmaceutica sinica B, 2015. 5(5): p. 402-418.

2. Bray, F., et al., Global cancer statistics 2018: GLOBOCAN estimates of incidence and mortality worldwide for 36 cancers in 185 countries. CA: a cancer journal for clinicians, 2018. 68(6): p. 394-424.

3. Mehlen, P. and A. Puisieux, Metastasis: a question of life or death. Nature reviews cancer, 2006. 6(6): p. 449-458.

4. Gupta, G.P. and J. Massagué, Cancer metastasis: building a framework. Cell, 2006. 127(4): p. 679-695.

5. Martin, T.A., et al., Cancer invasion and metastasis: molecular and cellular perspective, in Madame Curie Bioscience Database [Internet]. 2013, Landes Bioscience.

6. $\quad$ Fidler, I., Cancer metastasis. British medical bulletin, 1991. 47(1): p. 157-177.

7. Wells, A., et al., Targeting tumor cell motility as a strategy against invasion and metastasis. Trends in pharmacological sciences, 2013. 34(5): p. 283-289.

8. Varki, A. and N. Sharon, Historical background and overview. Essentials of Glycobiology. 2nd edition, 2009.

9. Varki, A., Biological roles of glycans. Glycobiology, 2017. 27(1): p. 3-49.

10. Varki, A. and P. Gagneux, Biological functions of glycans. 2017.

11. Ohtsubo, K. and J.D. Marth, Glycosylation in cellular mechanisms of health and disease. Cell, 2006. 126(5): p. 855-867.

12. Seeberger, P.H., Monosaccharide Diversity, in Essentials of Glycobiology, rd, et al., Editors. 2015: Cold Spring Harbor (NY). p. 19-30.

13. Hart, G.W., Glycosylation. Current opinion in cell biology, 1992. 4(6): p. 1017-1023.

14. Prestegard, J.H., J. Liu, and G. Widmalm, Oligosaccharides and Polysaccharides, in Essentials of Glycobiology, rd, et al., Editors. 2015: Cold Spring Harbor (NY). p. 31-40.

15. Muthana, S.M., C.T. Campbell, and J.C. Gildersleeve, Modifications of glycans: biological significance and therapeutic opportunities. ACS Chem Biol, 2012. 7(1): p. 31-43.

16. Reily, C., et al., Glycosylation in health and disease. Nature Reviews Nephrology, 2019. 15(6): p. 346-366. 
17. Flynn, R.A., et al., Small RNAs are modified with $N$-glycans and displayed on the surface of living cells. Cell, 2021.

18. Wagner, G.K. and T. Pesnot, Glycosyltransferases and their assays. ChemBioChem, 2010. 11(14): p. 1939-1949.

19. Freeze, H.H. and A.D. Elbein, Glycosylation precursors. Essentials of Glycobiology. 2nd edition, 2009.

20. Stanley, P., N. Taniguchi, and M. Aebi, N-glycans. Essentials of Glycobiology [Internet]. 3rd edition, 2017.

21. Brockhausen, I., H. Schachter, and P. Stanley, O-GalNAc glycans. Essentials of Glycobiology. 2nd edition, 2009.

22. Suzuki, Y., et al., Sialic acid species as a determinant of the host range of influenza $A$ viruses. Journal of virology, 2000. 74(24): p. 11825-11831.

23. Bojar, D., et al., Deep-Learning Resources for Studying Glycan-Mediated Host-Microbe Interactions. Cell Host \& Microbe, 2021. 29(1): p. 132-144. e3.

24. Jaeken, J., Congenital disorders of glycosylation (CDG): update and new developments. $\mathrm{J}$ Inherit Metab Dis, 2004. 27(3): p. 423-6.

25. Ng, B.G. and H.H. Freeze, Perspectives on Glycosylation and Its Congenital Disorders. Trends Genet, 2018. 34(6): p. 466-476.

26. Pinho, S.S. and C.A. Reis, Glycosylation in cancer: mechanisms and clinical implications. Nat Rev Cancer, 2015. 15(9): p. 540-55.

27. Varki, A., et al., Glycosylation Changes in Cancer, in Essentials of Glycobiology, rd, et al., Editors. 2015: Cold Spring Harbor (NY). p. 597-609.

28. Mereiter, S., et al., Glycosylation in the Era of Cancer-Targeted Therapy: Where Are We Heading? Cancer Cell, 2019. 36(1): p. 6-16.

29. Varki, A., R.L. Schnaar, and R. Schauer, Sialic acids and other nonulosonic acids. Essentials of Glycobiology [Internet]. 3rd edition, 2017.

30. Schauer, R., Sialic acids: chemistry, metabolism, and function. Vol. 10. 2012: Springer Science \& Business Media.

31. Schauer, R., et al., Biochemistry and role of sialic acids. Biology of the sialic acids, 1995: p. 7-67.

32. Varki, A., Sialic acids in human health and disease. Trends in molecular medicine, 2008. 14(8): p. 351-360.

33. Chen, X. and A. Varki, Advances in the biology and chemistry of sialic acids. ACS chemical biology, 2010. 5(2): p. 163-176.

34. Angata, T. and A. Varki, Chemical diversity in the sialic acids and related $\alpha$-keto acids: an evolutionary perspective. Chemical reviews, 2002. 102(2): p. 439-470.

35. Varki, A., Diversity in the sialic acids. Glycobiology, 1992. 2(1): p. 25.

36. Cohen, M. and A. Varki, The sialome-far more than the sum of its parts. Omics: a journal of integrative biology, 2010. 14(4): p. 455-464.

37. Li, Y. and X. Chen, Sialic acid metabolism and sialyltransferases: natural functions and applications. Applied microbiology and biotechnology, 2012. 94(4): p. 887-905. 
38. Dall'Olio, F. and M. Chiricolo, Sialyltransferases in cancer. Glycoconjugate journal, 2001. 18(11): p. 841-850.

39. Wang, P.-H., Altered glycosylation in cancer: sialic acids and sialyltransferases. J Cancer Mol, 2005. 1(2): p. 73-81.

40. Pearce, O.M. and H. Läubli, Sialic acids in cancer biology and immunity. Glycobiology, 2016. 26(2): p. 111-128.

41. Vajaria, B.N. and P.S. Patel, Glycosylation: a hallmark of cancer? Glycoconjugate journal, 2017. 34(2): p. 147-156.

42. Büll, C., et al., Sialic acids sweeten a tumor's life. Cancer research, 2014. 74(12): p. 31993204.

43. Harduin-Lepers, A., et al., Sialyltransferases functions in cancers. Frontiers in bioscience (Elite edition), 2012. 4: p. 499-515.

44. Häuselmann, I. and L. Borsig, Altered tumor-cell glycosylation promotes metastasis. Frontiers in oncology, 2014. 4: p. 28.

45. Almaraz, R.T., et al., Metabolic flux increases glycoprotein sialylation: implications for cell adhesion and cancer metastasis. Molecular \& Cellular Proteomics, 2012. 11(7): p. M112. 017558-1-M112. 017558-12.

46. Rodrigues, E. and M.S. Macauley, Hypersialylation in cancer: modulation of inflammation and therapeutic opportunities. Cancers, 2018. 10(6): p. 207.

47. Sherr, C.J., Cancer cell cycles. Science, 1996. 274(5293): p. 1672-1677.

48. Swindall, A.F. and S.L. Bellis, Sialylation of the Fas death receptor by ST6Gal-I provides protection against Fas-mediated apoptosis in colon carcinoma cells. Journal of Biological Chemistry, 2011. 286(26): p. 22982-22990.

49. Wu, X., et al., Sialyltransferase ST3GAL1 promotes cell migration, invasion, and TGF- $\beta 1$ induced EMT and confers paclitaxel resistance in ovarian cancer. Cell death \& disease, 2018. 9(11): p. 1-14.

50. Schultz, M.J., et al., ST6Gal-I sialyltransferase confers cisplatin resistance in ovarian tumor cells. Journal of ovarian research, 2013. 6(1): p. 1-9.

51. Kvorjak, M., et al., Cross-talk between Colon Cells and Macrophages Increases ST6GALNAC1 and MUC1-sTn Expression in Ulcerative Colitis and Colitis-Associated Colon Cancer. Cancer immunology research, 2020. 8(2): p. 167-178.

52. Freitas, D., et al., O-glycans truncation modulates gastric cancer cell signaling and transcription leading to a more aggressive phenotype. EBioMedicine, 2019. 40: p. 349362.

53. Cohen, E.N., et al., Elevated serum levels of sialyl Lewis X (sLe X) and inflammatory mediators in patients with breast cancer. Breast cancer research and treatment, 2019. 176(3): p. 545-556.

54. Jin, Y., et al., Use of protein-based biomarkers of exfoliated cervical cells for primary screening of cervical cancer. Archives of pharmacal research, 2018. 41(4): p. 438-449.

55. Samraj, A., et al., Involvement of a non-human sialic acid in human cancer. Frontiers in oncology, 2014. 4: p. 33. 
56. Samraj, A.N., et al., A red meat-derived glycan promotes inflammation and cancer progression. Proceedings of the National Academy of Sciences, 2015. 112(2): p. 542-547.

57. Altman, M.O. and P. Gagneux, Absence of Neu5Gc and presence of anti-Neu5Gc antibodies in humans - an evolutionary perspective. Frontiers in immunology, 2019. 10: p. 789.

58. Zhang, Q., et al., Mass spectrometry for protein sialoglycosylation. Mass spectrometry reviews, 2018. 37(5): p. 652-680.

59. Yamamoto, K., Y. Konami, and T. Irimura, Sialic acid-binding motif of Maackia amurensis lectins. The Journal of Biochemistry, 1997. 121(4): p. 756-761.

60. Shibuya, N., et al., The elderberry (Sambucus nigra L.) bark lectin recognizes the Neu5Ac (alpha 2-6) Gal/GalNAc sequence. Journal of Biological Chemistry, 1987. 262(4): p. 1596-1601.

61. Zhou, X., G. Yang, and F. Guan, Biological functions and analytical strategies of sialic acids in tumor. Cells, 2020. 9(2): p. 273.

62. BelBruno, J.J., Molecularly imprinted polymers. Chemical reviews, 2018. 119(1): p. 94119.

63. Chang, P.V., et al., Metabolic labeling of sialic acids in living animals with alkynyl sugars. Angewandte Chemie International Edition, 2009. 48(22): p. 4030-4033.

64. Wen, L., et al., A one-step chemoenzymatic labeling strategy for probing sialylated Thomsen-Friedenreich antigen. ACS central science, 2018. 4(4): p. 451-457.

65. Yu, H., et al., Chemoenzymatic synthesis of GD3 oligosaccharides and other disialyl glycans containing natural and non-natural sialic acids. Journal of the American Chemical Society, 2009. 131(51): p. 18467-18477.

66. Haupt, K. and K. Mosbach, Molecularly imprinted polymers and their use in biomimetic sensors. Chemical reviews, 2000. 100(7): p. 2495-2504.

67. Haupt, K., Molecularly imprinted polymers in analytical chemistry. Analyst, 2001. 126(6): p. 747-756.

68. Zhang, X., M. Zhu, and S. Li, “Key-vs.-Lock”-Like Polymer Reactor Made of Molecularly Imprinted Polymer Containing Metal Nanoparticles. Journal of Inorganic and Organometallic Polymers and Materials, 2014. 24(5): p. 890-897.

69. Dickey, F.H., The preparation of specific adsorbents. Proceedings of the National Academy of Sciences of the United States of America, 1949. 35(5): p. 227.

70. Pauling, L., A theory of the structure and process of formation of antibodies. Journal of the American Chemical Society, 1940. 62(10): p. 2643-2657.

71. Wulff, G., The use of polymers with enzyme-analogous structures for the resolution of racemates. Angrew. Chem. Internat. Edit., 1972. 11(4): p. 341.

72. Takagishi, T. and I.M. Klotz, Macromolecule - small molecule interactions; introduction of additional binding sites in polyethyleneimine by disulfide cross-linkages. Biopolymers: Original Research on Biomolecules, 1972. 11(2): p. 483-491. 
73. Sellergren, B., M. Lepistoe, and K. Mosbach, Highly enantioselective and substrateselective polymers obtained by molecular imprinting utilizing noncovalent interactions. NMR and chromatographic studies on the nature of recognition. Journal of the American chemical society, 1988. 110(17): p. 5853-5860.

74. El-Schich, Z., et al., Molecularly imprinted polymers in biological applications. BioTechniques, 2020. 69(6): p. 406-419.

75. Mohajeri, S.A., et al., Clozapine recognition via molecularly imprinted polymers; bulk polymerization versus precipitation method. Journal of Applied Polymer Science, 2011. 121(6): p. 3590-3595.

76. Wang, X., et al., Magnetic molecularly imprinted polymer particles synthesized by suspension polymerization in silicone oil. Macromolecular rapid communications, 2006. 27(14): p. 1180-1184.

77. Hasanah, A.N., et al., Extraction of atenolol from spiked blood serum using a molecularly imprinted polymer sorbent obtained by precipitation polymerization. Heliyon, 2019. 5(4): p. e01533.

78. Shao, Y., et al., Preparation of novel magnetic molecular imprinted polymers nanospheres via reversible addition-fragmentation chain transfer polymerization for selective and efficient determination of tetrabromobisphenol A. Journal of hazardous materials, 2017. 339: p. 418-426.

79. Ming, W., et al., Magnetic molecularly imprinted polymers for the fluorescent detection of trace 17ß-estradiol in environmental water. Sensors and Actuators B: Chemical, 2017. 238: p. 1309-1315.

80. Ansari, S. and M. Karimi, Recent configurations and progressive uses of magnetic molecularly imprinted polymers for drug analysis. Talanta, 2017. 167: p. 470-485.

81. Shinde, S., et al., Sialic acid-imprinted fluorescent core-shell particles for selective labeling of cell surface glycans. Journal of the American Chemical Society, 2015. 137(43): p. 13908-13912.

82. Wang, H.-F., et al., Surface molecular imprinting on Mn-doped ZnS quantum dots for room-temperature phosphorescence optosensing of pentachlorophenol in water. Analytical chemistry, 2009. 81(4): p. 1615-1621.

83. Ensafi, A.A., P. Nasr-Esfahani, and B. Rezaei, Synthesis of molecularly imprinted polymer on carbon quantum dots as an optical sensor for selective fluorescent determination of promethazine hydrochloride. Sensors and Actuators B: Chemical, 2018. 257: p. 889-896.

84. Ji, W., et al., Preparation of hydrophilic molecularly imprinted polymers via bulk polymerization combined with hydrolysis of ester groups for selective recognition of iridoid glycosides. Analytical and bioanalytical chemistry, 2016. 408(19): p. 5319-5328.

85. Mayor, M.G., et al., Synthesis and characterization of a molecularly imprinted polymer for the determination of spiramycin in sheep milk. Food chemistry, 2017. 221: p. 721-728.

86. Lin, Z.-z., et al., Application of magnetic molecularly imprinted polymers in the detection of malachite green in fish samples. Reactive and Functional Polymers, 2016. 98: p. 24-30. 
87. Alizadeh, T., et al., Synthesis of nano-sized timolol-imprinted polymer via ultrasonication assisted suspension polymerization in silicon oil and its use for the fabrication of timolol voltammetric sensor. Materials Science and Engineering: C, 2017. 77: p. 300-307.

88. Sun, Y., et al., Molecularly imprinted polymers fabricated by Pickering emulsion polymerization for the selective adsorption and separation of quercetin from Spina Gleditsiae. New Journal of Chemistry, 2019. 43(37): p. 14747-14755.

89. Zhu, F., L. Li, and J. Xing, Selective adsorption behavior of Cd (II) ion imprinted polymers synthesized by microwave-assisted inverse emulsion polymerization: Adsorption performance and mechanism. Journal of hazardous materials, 2017. 321: p. 103-110.

90. Zheng, X., et al., Preparation of hollow porous molecularly imprinted polymers for $\mathrm{N}$ nitrosamine adsorption. Materials Letters, 2018. 211: p. 21-23.

91. Haginaka, J., et al., Retention and molecular-recognition mechanisms of molecularly imprinted polymers for promazine derivatives. Talanta, 2019. 205: p. 120149.

92. Nakamura, Y., H. Matsunaga, and J. Haginaka, Preparation of molecularly imprinted polymers for strychnine by precipitation polymerization and multistep swelling and polymerization and their application for the selective extraction of strychnine from nux vomica extract powder. Journal of separation science, 2016. 39(8): p. 1542-1550.

93. Lu, Y., et al., Synthesizing vitamin E molecularly imprinted polymers via precipitation polymerization. Journal of Chemical \& Engineering Data, 2019. 64(3): p. 1045-1050.

94. Chen, F., et al., Microwave-assisted RAFT polymerization of well-constructed magnetic surface molecularly imprinted polymers for specific recognition of benzimidazole residues. Applied Surface Science, 2018. 435: p. 247-255.

95. Bitar, M., et al., Molecularly imprinted sol-gel polymers for the analysis of iprodione fungicide in wine: Synthesis in green solvent. Food chemistry, 2019. 293: p. 226-232.

96. da Costa Silva, R.G. and F. Augusto, Sol-gel molecular imprinted ormosil for solid-phase extraction of methylxanthines. Journal of Chromatography A, 2006. 1114(2): p. 216-223.

97. Wang, S., et al., Targeting and imaging of cancer cells via monosaccharide-imprinted fluorescent nanoparticles. Scientific reports, 2016. 6(1): p. 1-11.

98. Panagiotopoulou, M., et al., Fluorescent molecularly imprinted polymers as plastic antibodies for selective labeling and imaging of hyaluronan and sialic acid on fixed and living cells. Biosensors and Bioelectronics, 2017. 88: p. 85-93.

99. Xing, R., et al., Preparation of molecularly imprinted polymers specific to glycoproteins, glycans and monosaccharides via boronate affinity controllable-oriented surface imprinting. Nature protocols, 2017. 12(5): p. 964-987.

100. Sharma, G. and B. Kandasubramanian, Molecularly imprinted polymers for selective recognition and extraction of heavy metal ions and toxic dyes. Journal of Chemical \& Engineering Data, 2020. 65(2): p. 396-418.

101. Zangiabadi, M. and Y. Zhao, Molecularly Imprinted Polymeric Receptors with Interfacial Hydrogen Bonds for Peptide Recognition in Water. ACS Applied Polymer Materials, 2020. 2(8): p. 3171-3180. 
102. Bossi, A.M., et al., Fingerprint-imprinted polymer: rational selection of peptide epitope templates for the determination of proteins by molecularly imprinted polymers. Analytical chemistry, 2012. 84(9): p. 4036-4041.

103. Dabrowski, M., et al., Nanostructured molecularly imprinted polymers for protein chemosensing. Biosensors and Bioelectronics, 2018. 102: p. 17-26.

104. El-Schich, Z., et al., Sialic acid as a biomarker studied in breast cancer cell lines in vitro using fluorescent molecularly imprinted polymers. Applied Sciences, 2021. 11(7): p. 3256.

105. Yang, J., et al., A novel fluorescence molecularly imprinted sensor for Japanese encephalitis virus detection based on metal organic frameworks and passivation-enhanced selectivity. Talanta, 2020. 212: p. 120744.

106. Li, P., et al., Molecularly Imprinted Polymer Sensor Arrays, in Molecularly Imprinted Polymers for Analytical Chemistry Applications. 2018. p. 447-474.

107. Canfarotta, F., et al., Specific drug delivery to cancer cells with double-imprinted nanoparticles against epidermal growth factor receptor. Nano letters, 2018. 18(8): p. 4641-4646.

108. Grivennikov, S.I., F.R. Greten, and M. Karin, Immunity, inflammation, and cancer. Cell, 2010. 140(6): p. 883-899.

109. Galdiero, M.R., G. Marone, and A. Mantovani, Cancer inflammation and cytokines. Cold Spring Harbor perspectives in biology, 2018. 10(8): p. a028662.

110. Coussens, L.M. and Z. Werb, Inflammation and cancer. Nature, 2002. 420(6917): p. 860867.

111. Bonavita, E., et al., Phagocytes as corrupted policemen in cancer-related inflammation. Advances in cancer research, 2015. 128: p. 141-171.

112. Sfanos, K.S. and A.M. De Marzo, Prostate cancer and inflammation: the evidence. Histopathology, 2012. 60(1): p. 199-215.

113. Malhab, L.J.B., et al., Chronic Inflammation and Cancer: The Role of Endothelial Dysfunction and Vascular Inflammation. Current Pharmaceutical Design, 2021.

114. Zhang, Y., et al., Determination of cytokine regulated glycan expression by using molecularly imprinted polymers targeting sialic acid. Journal of cancer metastasis and treatment, 2019. 56(5).

115. Zhang, J.-M. and J. An, Cytokines, inflammation and pain. International anesthesiology clinics, 2007. 45(2): p. 27.

116. Korniluk, A., et al., From inflammation to cancer. Irish Journal of Medical Science (1971), 2017. 186(1): p. 57-62.

117. Libby, P., P.M. Ridker, and A. Maseri, Inflammation and atherosclerosis. Circulation, 2002. 105(9): p. 1135-1143.

118. Qu, G., et al., An imperative need for research on the role of environmental factors in transmission of novel coronavirus (COVID-19). 2020, ACS Publications.

119. Awadasseid, A., et al., Initial success in the identification and management of the coronavirus disease 2019 (COVID-19) indicates human-to-human transmission in Wuhan, China. International journal of biological sciences, 2020. 16(11): p. 1846. 
120. Hoffmann, M., et al., SARS-CoV-2 cell entry depends on ACE2 and TMPRSS2 and is blocked by a clinically proven protease inhibitor. cell, 2020. 181(2): p. 271-280. e8.

121. WHO data-MERS-CoV.

122. Zhou, P., et al., A pneumonia outbreak associated with a new coronavirus of probable bat origin. nature, 2020. 579(7798): p. 270-273.

123. Yan, R., et al., Structural basis for the recognition of SARS-CoV-2 by full-length human ACE2. Science, 2020. 367(6485): p. 1444-1448.

124. Liu, S.-L., et al., No credible evidence supporting claims of the laboratory engineering of SARS-CoV-2. Emerging Microbes \& Infections, 2020. 9(1): p. 505-507.

125. WHO, Transmission of SARS-CoV-2: implications for infection prevention precautions. Scientific brief, 09 July 2020, 2020: p. 1-10.

126. WHO data. 2021.

127. Wang, C., et al., The establishment of reference sequence for SARS - CoV - 2 and variation analysis. Journal of medical virology, 2020. 92(6): p. 667-674.

128. Lan, J., et al., Structure of the SARS-CoV-2 spike receptor-binding domain bound to the ACE2 receptor. Nature, 2020. 581(7807): p. 215-220.

129. Chen, Y. and L. Li, SARS-CoV-2: virus dynamics and host response. The Lancet Infectious Diseases, 2020. 20(5): p. 515-516.

130. Wu, C., et al., Analysis of therapeutic targets for SARS-CoV-2 and discovery of potential drugs by computational methods. Acta Pharmaceutica Sinica B, 2020. 10(5): p. 766-788.

131. Klein, S., et al., SARS-CoV-2 structure and replication characterized by in situ cryoelectron tomography. Nature communications, 2020. 11(1): p. 1-10.

132. Shang, J., et al., Structural basis of receptor recognition by SARS-CoV-2. Nature, 2020. 581(7807): p. 221-224.

133. Cai, Y., et al., Distinct conformational states of SARS-CoV-2 spike protein. Science, 2020. 369(6511): p. 1586-1592.

134. Huang, Y., et al., Structural and functional properties of SARS-CoV-2 spike protein: potential antivirus drug development for COVID-19. Acta Pharmacologica Sinica, 2020. 41(9): p. 1141-1149.

135. Li, W., et al., Angiotensin-converting enzyme 2 is a functional receptor for the SARS coronavirus. Nature, 2003. 426(6965): p. 450-454.

136. Cohen, J.B., et al., Relationship between ACE2 and other components of the reninangiotensin system. Current Hypertension Reports, 2020. 22(7): p. 1-5.

137. Voors, A.A., et al., Dual pathway for angiotensin II formation in human internal mammary arteries. British journal of pharmacology, 1998. 125(5): p. 1028-1032.

138. Sungnak, W., et al., SARS-CoV-2 entry factors are highly expressed in nasal epithelial cells together with innate immune genes. Nature medicine, 2020. 26(5): p. 681-687.

139. Rahman, N., et al., Virtual screening of natural products against Type II transmembrane serine protease (TMPRSS2), the priming agent of coronavirus 2 (SARS-CoV-2). Molecules, 2020. 25(10): p. 2271. 
140. Glowacka, I., et al., Evidence that TMPRSS2 activates the severe acute respiratory syndrome coronavirus spike protein for membrane fusion and reduces viral control by the humoral immune response. Journal of virology, 2011. 85(9): p. 4122-4134.

141. Thompson, A.J., R.P. de Vries, and J.C. Paulson, Virus recognition of glycan receptors. Current opinion in virology, 2019. 34: p. 117-129.

142. Air, G.M., Influenza virus-glycan interactions. Current opinion in virology, 2014. 7: p. 128-133.

143. Clausen, T.M., et al., SARS-CoV-2 infection depends on cellular heparan sulfate and ACE2. Cell, 2020. 183(4): p. 1043-1057. e15.

144. Park, Y.-J., et al., Structures of MERS-CoV spike glycoprotein in complex with sialoside attachment receptors. Nature structural \& molecular biology, 2019. 26(12): p. 1151-1157.

145. Tortorici, M.A., et al., Structural basis for human coronavirus attachment to sialic acid receptors. Nature structural \& molecular biology, 2019. 26(6): p. 481-489.

146. Dai, X., et al., Breast cancer cell line classification and its relevance with breast tumor subtyping. Journal of Cancer, 2017. 8(16): p. 3131.

147. Baeuerle, P. and O. Gires, EpCAM (CD326) finding its role in cancer. British journal of cancer, 2007. 96(3): p. 417-423.

148. Naor, D., et al., CD44 in cancer. Critical reviews in clinical laboratory sciences, 2002. 39(6): p. 527-579.

149. Johansson, E., et al., Pentavalent sialic acid conjugates block coxsackievirus A24 variant and human adenovirus type 37-viruses that cause highly contagious eye infections. ACS chemical biology, 2020. 15(10): p. 2683-2691.

150. Kimani, M., et al., Imprinted Particles for Direct Fluorescence Detection of Sialic Acid in Polar Media and on Cancer Cells with Enhanced Control of Nonspecific Binding. ACS Applied Polymer Materials, 2021. 3(5): p. 2363-2373.

151. Caraballo, R., et al., Triazole linker-based trivalent sialic acid inhibitors of adenovirus type 37 infection of human corneal epithelial cells. Organic \& biomolecular chemistry, 2015. 13(35): p. 9194-9205.

152. Zhang, Y., et al., Determination of cytokine regulated glycan expression by using molecularly imprinted polymers targeting sialic acid. Journal of cancer metastasis and treatment; 5, 2019. 56.

153. Cui, H., et al., Differential expression of the $\alpha 2$, 3-sialic acid residues in breast cancer is associated with metastatic potential. Oncology reports, 2011. 25(5): p. 1365-1371.

154. Christie, D.R., et al., ST6Gal-I expression in ovarian cancer cells promotes an invasive phenotype by altering integrin glycosylation and function. Journal of ovarian research, 2008. 1(1): p. 1-8.

155. Bassagañas, S., et al., Inflammatory cytokines regulate the expression of glycosyltransferases involved in the biosynthesis of tumor-associated sialylated glycans in pancreatic cancer cell lines. Cytokine, 2015. 75(1): p. 197-206.

156. Colman, P.M., Neuraminidase, in The influenza viruses. 1989, Springer. p. 175-218.

157. Yang, Q., et al., Inhibition of SARS-CoV-2 viral entry upon blocking $N$-and O-glycan elaboration. Elife, 2020. 9: p. e61552. 


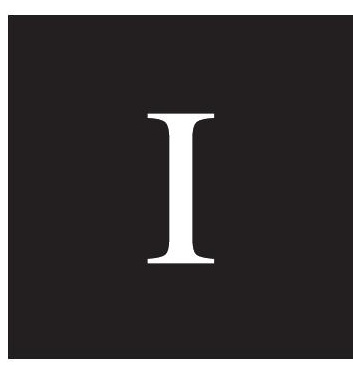





\title{
Sialic Acid as a Biomarker Studied in Breast Cancer Cell Lines In Vitro Using Fluorescent Molecularly Imprinted Polymers
}

\author{
Zahra El-Schich ${ }^{1,2}{ }^{D}$, Yuecheng Zhang ${ }^{1,2}$, Tommy Göransson ${ }^{1}$, Nishtman Dizeyi ${ }^{3}$, Jenny L. Persson ${ }^{1,2,4}$, \\ Emil Johansson ${ }^{5,6}$, Remi Caraballo ${ }^{5,6}$, Mikael Elofsson ${ }^{5,6} \mathbb{D}^{\mathbb{D}}$, Sudhirkumar Shinde ${ }^{7} \mathbb{D}$, Börje Sellergren ${ }^{1,2}$ \\ and Anette Gjörloff Wingren 1,2,* (D)

\section{check for} \\ updates \\ 1 Department of Biomedical Sciences, Faculty of Health and Society, Malmö University, \\ SE-205 06 Malmö, Sweden; zahra.el-schich@mau.se (Z.E.-S.); yuecheng.zhang@mau.se (Y.Z.); \\ tommy.goransson@skane.se (T.G.); jenny.persson@mau.se (J.L.P.); borje.sellergren@mau.se (B.S.) \\ 2 Biofilms-Research Center for Biointerfaces, Malmö University, SE-205 06 Malmö, Sweden \\ 3 Department of Translational Medicine, Lund University, SE-205 06 Malmö, Sweden; \\ nishtman.dizeyi@cernelle.se \\ 4 Department of Molecular Biology, Umeå University, 90187 Umeå, Sweden \\ 5 Department of Chemistry, Umeå University, 90187 Umeå, Sweden; emil.johansson@umu.se (E.J.); \\ remi.caraballo@umu.se (R.C.); mikael.elofsson@umu.se (M.E.) \\ 6 Umeå Centre for Microbial Research, Umeå University, 90187 Umeå, Sweden \\ 7 School of Consciousness, Vishwanath Karad Maharashtra Institute of Technology-World Peace University, \\ Kothrud, Pune 411038, India; sudhirkumar.shinde@mitwpu.edu.in \\ * Correspondence: anette.gjorloff-wingren@mau.se
}

Citation: El-Schich, Z.; Zhang, Y.; Göransson, T.; Dizeyi, N.; Persson, J.L.; Johansson, E.; Caraballo, R.; Elofsson, M.; Shinde, S.; Sellergren, B.; et al. Sialic Acid as a Biomarker Studied in Breast Cancer Cell Lines In Vitro Using Fluorescent Molecularly Imprinted Polymers. Appl. Sci. 2021, 11, 3256. https://doi.org/10.3390/ app 11073256

Academic Editors: Francesca Silvagno and Flaviu-Alexandru Tabaran

Received: 3 March 2021

Accepted: 1 April 2021

Published: 5 April 2021

Publisher's Note: MDPI stays neutral with regard to jurisdictional claims in published maps and institutional affiliations.

Copyright: (c) 2021 by the authors Licensee MDPI, Basel, Switzerland This article is an open access article distributed under the terms and conditions of the Creative Commons Attribution (CC BY) license (https:// creativecommons.org/licenses/by/ $4.0 /$ ).
Abstract: Sialylations are post-translational modifications of proteins and lipids that play important roles in many cellular events, including cell-cell interactions, proliferation, and migration. Tumor cells express high levels of sialic acid (SA), which are often associated with the increased invasive potential in clinical tumors, correlating with poor prognosis. To overcome the lack of natural SA-receptors, such as antibodies and lectins with high enough specificity and sensitivity, we have used molecularly imprinted polymers (MIPs), or "plastic antibodies", as nanoprobes. Because high expression of epithelial cell adhesion molecule (EpCAM) in primary tumors is often associated with proliferation and a more aggressive phenotype, the expression of EpCAM and CD44 was initially analyzed. The SA-MIPs were used for the detection of SA on the cell surface of breast cancer cells. Lectins that specifically bind to the a-2,3 SA and a-2,6 SA variants were used for analysis of SA expression, with both flow cytometry and confocal microscopy. Here we show a correlation of EpCAM and SA expression when using the SA-MIPs for detection of SA. We also demonstrate the binding pattern of the SA-MIPs on the breast cancer cell lines using confocal microscopy. Pre-incubation of the SA-MIPs with SA-derivatives as inhibitors could reduce the binding of the SA-MIPs to the tumor cells, indicating the specificity of the SA-MIPs. In conclusion, the SA-MIPs may be a new powerful tool in the diagnostic analysis of breast cancer cells.

Keywords: breast cancer; epithelial cell adhesion molecule; molecularly imprinted polymers; nanoparticles; sialic acid

\section{Introduction}

Breast cancer cannot be classified as one diseases, but is largely heterogeneous and therefore the diagnosis and treatment in affected women with breast cancer can vary. Although there is a recent improvement in overall survival rate, the mortality rate is high [1]. Proved by molecular profiling, breast cancer is comprised of several subgroups according to previous classification: luminal A, luminal B, basal-like, human epidermal growth factor receptor 2 (HER2)-positive and normal subgroups [2,3].

Cancer cells use several mechanisms to bypass recognition by the immune cells, thereby escaping immune surveillance and progressing through metastases [4]. The cir- 
culating tumor cells (CTCs) released from primary tumors are considered to have the capability to initiate distant metastasis. Detection and isolation of CTCs using the Food and Drug Administration (FDA)-approved CellSearch platform is based on automated immunomagnetic sorting and on expression of the epithelial cell adhesion molecule (EpCAM) and cytokeratin [5]. The expression of EpCAM in primary tumors is often associated with proliferation and a more aggressive phenotype, if it is considered as high [6]. Alternative methods are definitely needed for the detection of CTCs that are able to recognize a broader spectrum of phenotypes.

Alterations in protein glycosylation have a role in the transformation to cellular malignancy and cancer progression [7]. Sialic acid (SA), or 5-N-acetylneuraminic acid (Neu5Ac), is a monosaccharide that plays an important role in many biological processes in the cells [8]. SA is chemically bound to galactose (Gal) or N-acetylgalactosamine (GalNAc) and the underlying glycan via $\alpha-2,3$ or $\alpha-2,6$ glycosidic linkage [8]. For detection of $\alpha-2,3$ $\mathrm{SA}$, the lectin Maackia amurensis I (MAL I) is commonly used, and for detection of $\alpha-2,6$ SA, the lectin Sambucus nigra (SNA) is used. $\alpha-2,6-\mathrm{SA}$ can be found on the basolateral cell membrane, whereas $\alpha-2,3-S A$ seems to be more prominent on the apical cell membrane [9]

Increased levels of SA on tumor cells have been connected with poor prognosis of clinical tumors and increased invasive potential [10]. It has been shown that a high SA expression enhances migration and invasion by increasing integrin interaction and preventing immune cell recognition [11]. The upregulation of sialyltransferase expression is upregulated and results in the accumulation of SA on the surface of cells $[12,13]$.

Available lectins and glycan specific antibodies for detection of SA containing glycoconjugates do not perform well in, e.g., analytics of glycoproteomes and appropriate high-throughput cellular imaging technologies [14]. Therefore, the studies by us and others are of high importance to develop novel tools for glycan detection [15-17]. One such tool to prepare saccharide selective receptors is molecular imprinting [18]. Since Wulffs early reports on highly discriminative boronate-based receptors for monosaccharides [19], new promising imprinting approaches to design glycan or glycoprotein specific probes have been reported [20-27]. Indeed, the design of molecularly imprinted polymers (MIPs) and their use as artificial recognition elements have been shown to be successful for targeting glycans such as SA and glycosamino-glycans (GAGs) [15].

Liu et al. have reported, in a series of publications, an orientation controlled imprinting procedure using boronate anchored glycans [25]. This has resulted in glycan specific nanoprobes showing high selectivity for cell surface glycosylations. Using an innovative multilayered core-shell architecture comprising quantum dot cores, nanoprobes were developed for selective targeting and imaging of hyaluronan and sialylated glycosylation sites on human keratinocytes [22]. Based on a ternary complex imprinting procedure, we recently reported on fluorescently reporting SA imprinted nanoprobes for combined detection of both $\alpha-2,3$ and $\alpha-2,6$ SA on cancer cells. We demonstrated an affinity for various cell lines such as DU145, PC-3, Jurkat, and B-CLL and further verified the binding specificity by enzymatic cleavage of fluorescent SA-MIP nanoprobes for detection of SA on cancer cells $[20,21]$.

In the present study, we have performed screening of SA expression on a collection of breast cancer cell lines by using SA-MIPs and lectins, and analyzed SA-MIP targeting to the cells by flow cytometry and confocal fluorescence microscopy. The breast cancer cell lines were also analyzed using antibodies for the expression of the epithelial EpCAM and CD44, which is overexpressed in several cell types including cancer stem cells. We show that the SA-MIPs recognize breast cancer cells with low CD44 and high EpCAM expression, indicating that SA-MIPs can be used as an additional tool for detecting EpCAM positive breast cancer cells. The fluorescence microscopy images revealed the staining pattern of both lectins and SA-MIPs. Importantly, we show a novel use for SA-derivatives by pre-treating the SA-MIPs with these inhibitors before cell staining. Thereby, we could demonstrate a concentration-dependent reduction in binding of the SA-MIPs to breast cancer cells, indicating the specificity of the SA-MIP interaction. 


\section{Materials and Methods \\ 2.1. Cell Culture}

Human breast cancer cell lines T47D, MCF-7, Cama-1, MDAMB468, MDAMB231, and Hs-578T were obtained from the American Type Culture Collection (ATCC/LGC Standards, Teddington, UK). T47D and MCF-7 cells were cultured in Roswell Park Memorial Institute 1640 (RPMI-1640) medium supplemented with 10\% fetal bovine serum (FBS) and $50 \mathrm{ug} / \mathrm{mL}$ gentamycin. MDAMB468 and MDAMB231 cells were cultured in Dulbeccos Modified Eagle Medium (DMEM), supplemented with 10\% FBS. Cama-1 cells was cultured in RPMI-1640 medium supplemented with $10 \%$ FBS, $1 \%$ pyruvate sodium, and $1 \%$ penicillin streptomycin. Hs-578T cells was cultured in DMEM supplemented with 10\% FBS, 1\% penicillin streptomycin, and $10 \mathrm{ug} / \mathrm{mL}$ insulin (Sigma-Aldrich, St Louis, MO, USA). The cell lines were incubated at $37^{\circ} \mathrm{C}$ with $5 \% \mathrm{CO}_{2}$ in $100 \%$ humidity. All cell culture reagents, except for insulin, were from Thermo Fisher Scientific, Waltham, MA, USA).

\subsection{Flow Cytometry Analysis}

EpCAM staining: $1 \times 10^{6}$ cells/sample were stained with anti-EpCAM-PE, according to the manufacturer's instructions (Milentyi Biotec $\mathrm{GmBH}$, Bergisch Gladbach, Germany) or left unstained as a control. The cells were washed twice with $2 \mathrm{~mL}$ phosphate-buffered saline (PBS, Thermo Fisher Scientific). Anti-EpCAM-PE $(100 \mu \mathrm{L})$ with concentrations of 100,50 , and $10 \mathrm{ng} / \mathrm{mL}$ was added to the cells, and $100 \mu \mathrm{L}$ of PBS was used as a negative control. The cells were incubated with EpCAM-PE for $30 \mathrm{~min}$ at $4{ }^{\circ} \mathrm{C}$ in the dark and were thereafter washed three times with $2 \mathrm{~mL}$ PBS and analyzed using flow cytometry (BD Biosciences, Accuri C6 Flow Cytometry, NJ, USA).

CD44 staining: $1 \times 10^{6}$ cells/sample were stained with human anti-CD44 antibody, according to the manufacturer's instructions (R\&D, Minneapolis, MN, USA) or left unstained as a control. The cells were washed twice with $2 \mathrm{~mL}$ PBS. Anti-CD44 $(100 \mu \mathrm{L})$ with a concentration of $2.5 \mu \mathrm{g} / \mathrm{mL}$ was added to the cells, and $100 \mu \mathrm{L}$ of PBS was used as a negative control and incubated for $30 \mathrm{~min}$ at $4{ }^{\circ} \mathrm{C}$ in the dark. After incubation, the cells were washed twice with $2 \mathrm{~mL}$ PBS. Anti-rat fluorescein isothiocyanate (FITC, R\&D) was used as a secondary antibody. Anti-rat-FITC (100 $\mu \mathrm{L}$ of 1:10 diluted) was added to the cells and to the negative control. The cells were incubated for $30 \mathrm{~min}$ at $4{ }^{\circ} \mathrm{C}$ in the dark and were thereafter washed three times with $2 \mathrm{~mL}$ PBS and analyzed using flow cytometry.

MAL I and SNA (Lectin-Biotin): $1 \times 10^{6}$ cells/sample were stained with Lectin-Biotin, according to the manufacturer's instructions (Vector Laboratories, Burlingame, CA, USA) both for MAL I and SNA or left unstained as a control. The cells were washed twice with $2 \mathrm{~mL}$ PBS. Lectin-Biotin $(100 \mu \mathrm{L})$ with concentrations of 5,2 , and $1 \mu \mathrm{g} / \mathrm{mL}$ was added to the cells, and $100 \mu \mathrm{L}$ of PBS was used as a negative control. The cells were incubated with Lectin-Biotin for $30 \mathrm{~min}$ at $4{ }^{\circ} \mathrm{C}$ and were thereafter washed three times with $2 \mathrm{~mL}$ PBS. Thereafter, $100 \mu \mathrm{L}$ of 1:100 dilutions of streptavidin-FITC (Sigma) was added to the cells and incubated for $20 \mathrm{~min}$ at $4{ }^{\circ} \mathrm{C}$ in the dark. After the incubation, the cells were washed three times with $2 \mathrm{~mL}$ PBS and analyzed using flow cytometry.

SA-MIPs: The polymer particles (SA-MIPs) were prepared as previously described by Shinde et al. [20]. SA-MIPs equipped with nitrobenzoxadiazole (NBD) fluorescent reporter groups allowing environmentally sensitive fluorescence detection in green fluorescence. Here, $1 \times 10^{6}$ cells/sample were stained with SA-MIPs or left unstained as a control. The cells were washed twice with 2 mL PBS. SA-MIPs $(100 \mu \mathrm{L})$ with a concentration of $0.1 \mathrm{mg} / \mathrm{mL}$ was added to the cells, and $100 \mu \mathrm{L}$ of PBS was used as a negative control. The cells were incubated with SA-MIP for $30 \mathrm{~min}$ at $4{ }^{\circ} \mathrm{C}$ and were thereafter washed three times with $2 \mathrm{~mL}$ PBS and analyzed using flow cytometry.

\subsection{Fluorescence Microscopy}

Cells/sample $\left(5 \times 10^{4}\right)$ were adhered to poly-lysine slides (Thermo Fisher Scientific) in a 6 well-plate for $2 \mathrm{~h}$ at $37{ }^{\circ} \mathrm{C}$ with $5 \% \mathrm{CO}_{2}$ in $100 \%$ humidity. After the incubation, $2 \mathrm{~mL}$ cell culture medium was added to the wells and incubated for $48 \mathrm{~h}$. After the incubation, 
the cells were washed three times with PBS and fixed with $100 \mu \mathrm{L} 4 \%$ formaldehyde for $10 \mathrm{~min}$, followed by washing three times with PBS. After permeabilization with $0.05 \%$ TritonX (Sigma) the cells were incubated with rhodamine-Phalloidin (Sigma) for $30 \mathrm{~min}$ in the dark at room temperature (RT). After two more washings with $0.05 \%$ Triton- $X$ and PBS, the cells were incubated with $100 \mu \mathrm{L}$ of SA-MIPs $(0.1 \mathrm{mg} / \mathrm{mL})$ or biotinylated MAL I and SNA $(10 \mu \mathrm{g} / \mathrm{mL})$ for $30 \mathrm{~min}$ at RT. The biotinylated lectins were further incubated with streptavidin-FITC. After the incubation, the cells were washed four times with PBS and incubated with $100 \mu \mathrm{L} 300 \mathrm{nM}$ 4',6-diamidino-2-phenylindole (DAPI, Thermo Fisher Scientific) in PBS, for 4 min at RT. After three more washes with PBS, the cells were mounted with one drop of mounting medium ProlongQR Gold antifade reagent (Molecular probes).

Pre-treatment of SA-MIPs with SA- derivatives: The cells were harvested and washed twice with 2 mL PBS. SA-MIPs and two different SA-derivatives (ME0970 and ME1057) [28] at either $20 \mu \mathrm{M}$ or $200 \mu \mathrm{M}$ in $100 \mu \mathrm{L}$ were pre-incubated in PBS for 5 min before being added to $1 \times 10^{6}$ cells / sample, or were left unstained as a control. In addition, $100 \mu \mathrm{L}$ of SA-MIPs with a concentration of $0.1 \mathrm{mg} / \mathrm{mL}$ was used as a positive staining control. The cells were incubated for $30 \mathrm{~min}$ at $4{ }^{\circ} \mathrm{C}$ and were thereafter washed three times with $2 \mathrm{~mL}$ PBS and analyzed using flow cytometry.

\section{Results}

\subsection{Expression of EpCAM and CD44 on Breast Cancer Cell Lines}

The expression levels of EpCAM were analyzed in the six different breast cancer cell lines. Hs-578T and MDAMB231 expressed no EpCAM compared to MDAMB468, T47D, Cama-1, and MCF-7, which all expressed EpCAM at higher levels (Figure 1A). For CD44 expression, the Hs-578T, MDAMB231, and MDAMB468 expressed CD44 at high levels compared to T47D, Cama-1, and MCF-7, which expressed CD44 at lower levels (Figure 1B).

\subsection{SA Staining With Lectins on Breast Cancer Cell Lines}

In this study, two different lectins were used and analyzed by flow cytometry and fluorescence microscopy. MAL I appear to bind carbohydrate structures that contain SA attached to terminal galactose in $\alpha-2,3$ linkage. The $\alpha-2,3-S A$ expression is presented in Figure 2A. T47D, MDAMB231, and MCF-7 expressed high $\alpha-2,3$ linkage levels compared to Cama-1 and Hs-578T, which expressed low levels of $\alpha-2,3$ linkage, as determined by the mean fluorescence intensity (MFI). SNA binds preferentially to SA attached to terminal galactose in $\alpha-2,6$ and, to a lesser degree, $\alpha-2,3$ linkage. The $\alpha-2,6-S A$ expression is presented in Figure 2B. T47D and MDAMB468 showed the highest $\alpha-2,6$ linkage levels compared to MCF-7 and Hs-578T, which showed low levels of $\alpha-2,6$ linkage. The fluorescent microscopy results correlate well with the flow cytometry results (Figure 3). 
A
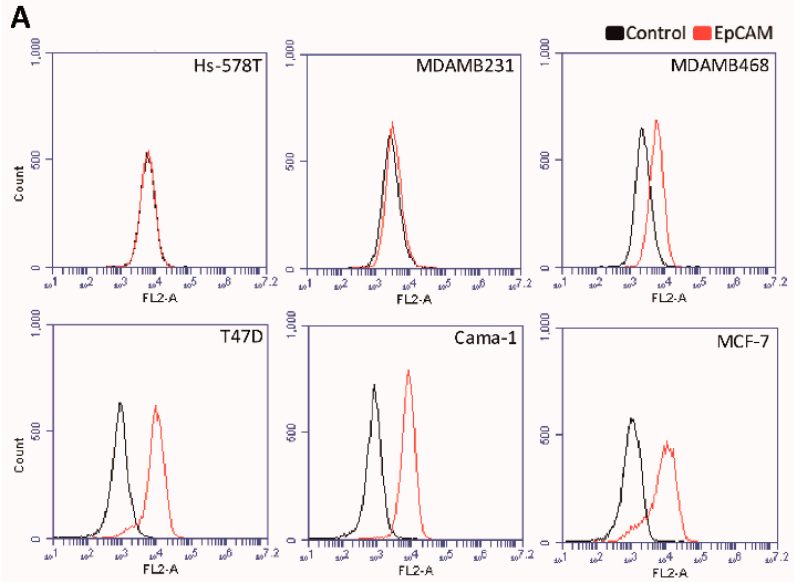

B
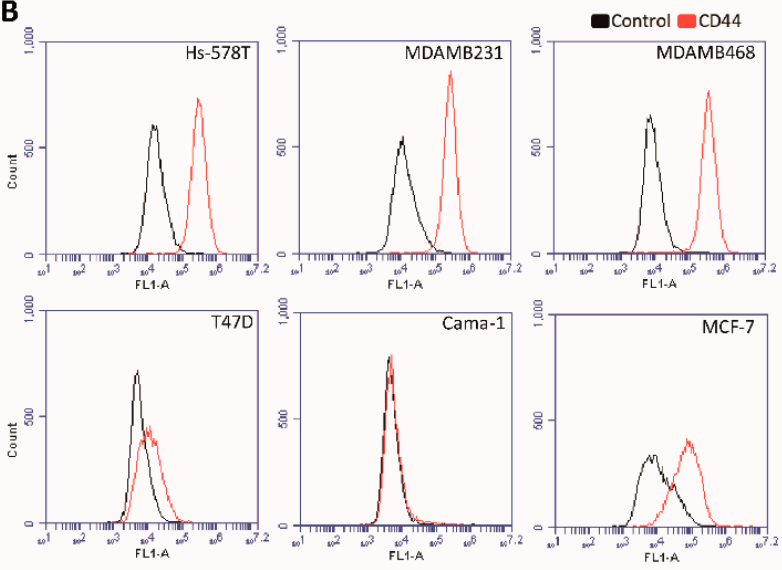

Figure 1. Epithelial cell adhesion molecule (EpCAM) and CD44 expression was analyzed with flow cytometry. Six different breast cancer cell lines were analyzed for EpCAM (A) and CD44 (B) expression patterns. The histograms shows the mean fluorescence intensity (MFI) for each staining in red, including background control in black. 


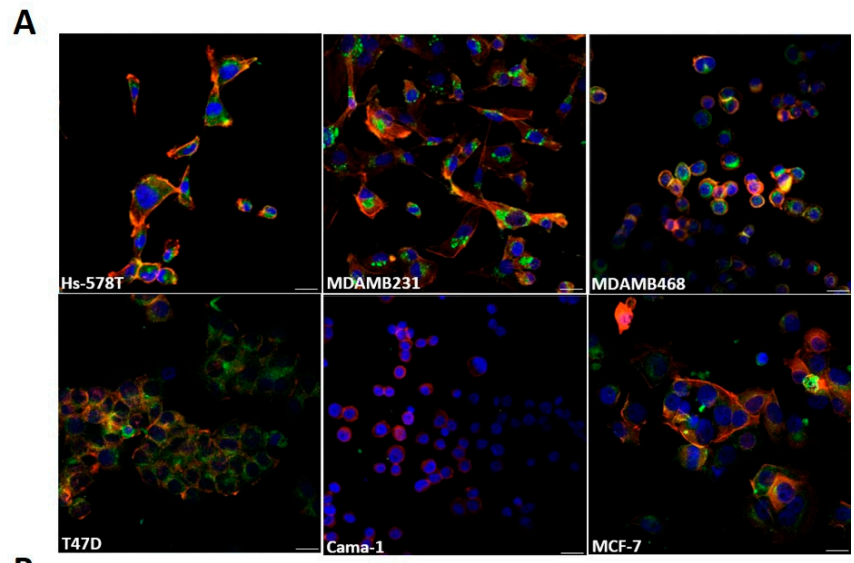

B



Figure 2. Fluorescence confocal microscopy of Maackia amurensis I (MAL I)—scale bar $20 \mu \mathrm{m}$. Six different breast cancer cell lines were stained for MAL I using fluorescein isothiocyanate (FITC, green), actin filament using rhodamine-phalloidin (red), and 4',6-diamidino-2-phenylindole (DAPI) nuclear staining (in blue), and analyzed with fluorescence confocal microscopy (A). Fluorescence microscopy of Sambucus nigra (SNA)—scale bar $10 \mu \mathrm{m}$. Six different breast cancer cell lines were stained for SNA in green, actin filament in red, and nuclear in blue, and analyzed with fluorescence confocal microscopy (B).

\subsection{SA Staining with SA-MIPs on Breast Cancer Cell Lines}

The expression levels for SA were analyzed using SA-MIPs and flow cytometry in six different breast cancer cell lines. According to the binding pattern, Hs-578T and MDAMB231 expressed SA at low levels compared to MDAMB468, T47D, Cama-1, and MCF-7, which expressed SA at higher levels (Figure 4A). Interestingly, the results indicate that low EpCAM expression levels correlate with low SA expression levels (Figure 4B). In addition, there is an inverse correlation between SA- and CD44-expression. In order to visualize the surface binding of SA, breast cancer cell lines were stained with SA-MIPs and analyzed with fluorescent microscopy. In Figure 5, the membrane staining of the breast cancer cell lines using SA-MIPs, actin filament staining with rhodamine-phalloidin, and nuclei staining using DAPI is shown. 

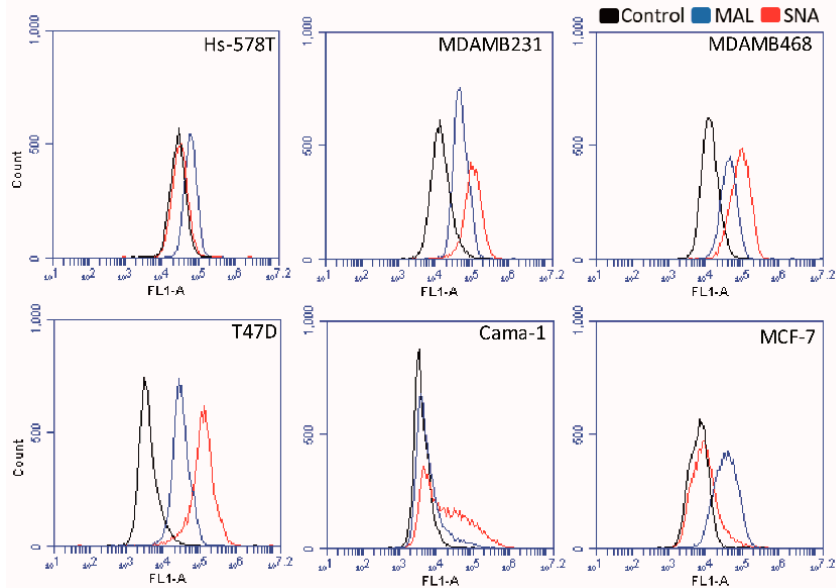

Figure 3. Six breast cancer cell lines were stained with either MAL I or SNA and analyzed with flow cytometry. The histograms show the MFI for each staining, MAL I in blue, SNA in red including background control in black.

A
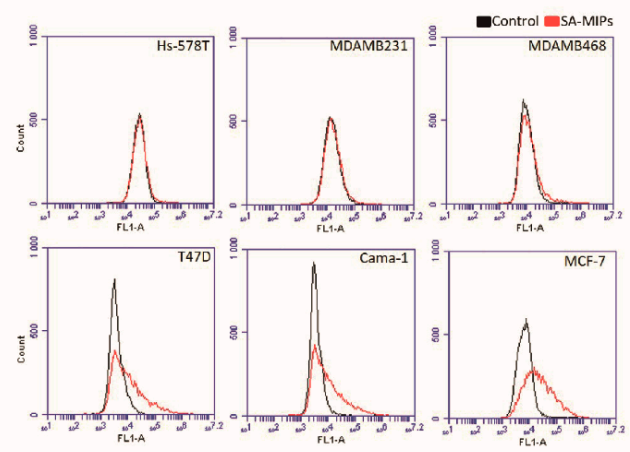

B

- SA-MIPS IEPCAM ICD44

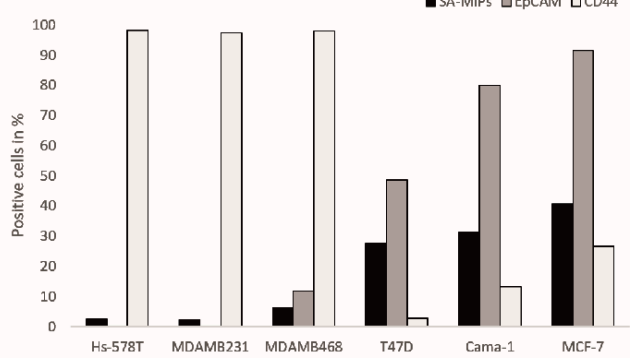

Figure 4. Six breast cancer cell lines were stained with SA-MIPs and analyzed with flow cytometry. The histograms shows the MFI for each staining, SA-MIPs in red including background control in black (A). EpCAM, CD44, and SA-MIPs analyzed with flow cytometry. Six different breast cancer cell lines were analyzed for EpCAM, CD44, and SA expression patterns. Results are shown in \% positive cells (B). 


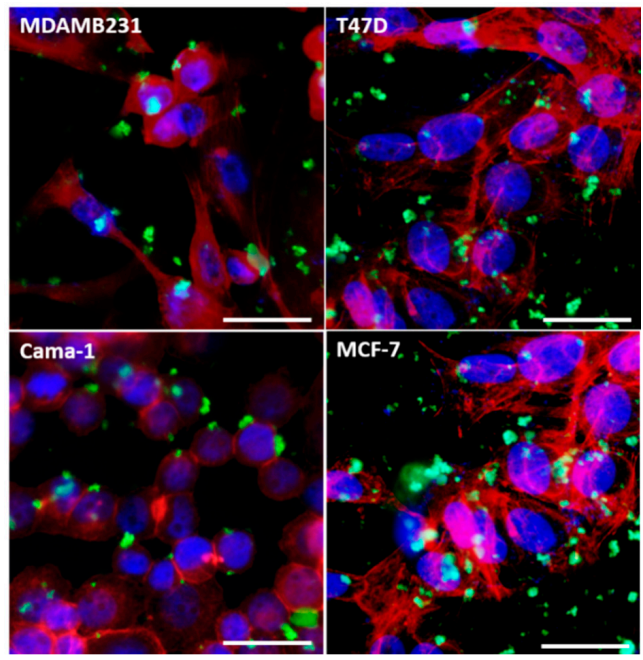

Figure 5. Fluorescence confocal microscopy SA-MIPs—scale bar $20 \mu \mathrm{m}$. Four different breast cancer cell lines were stained with SA-MIPs using nitrobenzoxadiazole (NBD) in green, rhodaminephalloidin (actin filaments) in red, and DAPI (nuclei) in blue, and analyzed with fluorescence confocal microscopy.

\subsection{Pre-Treatment of SA-MIPs with SA-Derivative Reduce the Binding to Cells}

The SA-derivatives ME0970 or ME1057 were pre-incubated at either $20 \mu \mathrm{M}$ or $200 \mu \mathrm{M}$, respectively, with $0.1 \mathrm{mg} / \mathrm{mL}$ SA-MIPs and were then added to the T47D cells. The binding of the pre-treated cells was compared with the binding to the same cell line of $0.1 \mathrm{mg} / \mathrm{mL}$ of SA-MIPs alone, and was shown to be reduced by $7 \%(20 \mu \mathrm{M})$ and $66 \%(200 \mu \mathrm{M})$, respectively, for ME0970, and by $0.5 \%(20 \mu \mathrm{M})$ and $64 \%(200 \mu \mathrm{M})$, respectively, for ME1057 (Figure 6). The reduction in binding of the pre-treated cells was concentration-dependent, as shown with both SA-derivatives.
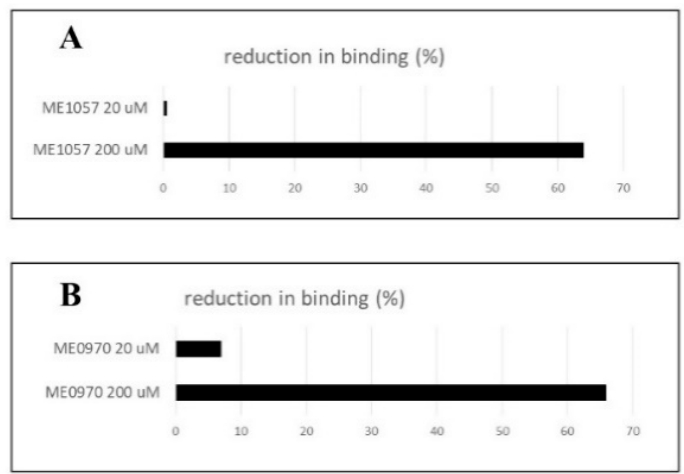

Figure 6. SA-MIPs were pre-incubated with different concentrations of the SA-derivatives and analyzed with flow cytometry. The reduction of binding compared to SA-MIP binding alone is shown. (A) The SA-derivative ME1057 was added at $20 \mu \mathrm{M}$ and $200 \mu \mathrm{M}$. (B) ME0970 was added at $20 \mu \mathrm{M}$ and $200 \mu \mathrm{M}$. 


\section{Discussion}

Glycosylation is the most abundant post-translational modification, and the majority of eukaryotic cells express cell surface glycans [29]. Knowledge about glycome has increased in the past few years. Indeed, the role of glycans in cancer have been highlighted by the fact that alterations in glycosylation regulate the development and progression of cancer. Thus, glycans serve as important biomarkers. We have developed SA-imprinted fluorescent nanoprobes to enable SA-detection, for use as novel tools in cancer diagnostics [20]. The correlation of SA-MIP binding and EpCAM expression on the breast cancer cell lines presented in this study show an additive level of phenotyping of breast cancer cells, together with the CD44 biomarker, which showed a reverse correlation. High expression levels of EpCAM in tumors are often associated with proliferation and a more aggressive phenotype with respect to overall survival and appearance of metastasis [6]. Identification of EpCAM glycosylation sites or structures may be a crucial step to define the potential role of EpCAM in breast cancer cells [30]. Various cancer cells are lacking EpCAM expression, therefore CellSearch approaches are limited [31]. Indeed, carcinoma cells undergoing epithelial-to-mesenchymal transition can at least partially downregulate epithelial cellspecific molecules such as EpCAM [32]. Several glycosylated markers could be of interest for study, including CD24, a highly glycosylated mucin-like antigen that has recently emerged as a novel oncogene and metastasis promoter in breast carcinoma [33].

Our results show that breast cancer cells expressing $\alpha-2,3$ or $\alpha-2,6$ glycosidic linkage can bind the SA-MIPs to various degrees. The fluorescence confocal microscopy results show the binding pattern of the SA-MIPs to the different cell types. For flow cytometry analysis, we could characterize the binding pattern of MAL I, SNA, and SA-MIPs to all six cell lines. In order to validate that binding of the MIPs to cells is mediated by direct interaction with SA, the MIPs were pre-incubated with pentavalent SA-derivatives. These derivatives were designed to block attachment of coxsackievirus A24V and adenovirus 37 viruses to host cells [28]. The viruses use multivalent attachment, and these defined SA-derivatives are efficacious in cell based infection and attachment assays in contrast to the SA monosaccharide that need to be used in $\mathrm{mM}$ concentrations to observe week inhibition. We hypothesized that these derivatives, with their flexible and long spacers, should be capable of binding to the MIPs and thereby reduce cell binding. Indeed, the results showed that the binding of the SA-MIPs to the cell line T47D could be inhibited by the addition of two different SA-derivatives. Because of their efficient inhibition ability, SA-derivatives can be used for specificity tests for SA-MIPs. The two SA-derivatives used in this study were designed from multivalent ligands intended for topical administration for the viruses CVA24v and HAdV-37 that utilize SA for cell attachment [28].

Others have shown that SA-imprinted nanoparticles could selectively bind with the SA overexpressed in DU145 cancer cells [25]. In their hands, DU145 cells, but not HeLa cells, bound the SA-imprinted nanoparticles, revealing a specificity in binding. Moreover, unmodified nanoparticles did not show any binding to the two cell lines. Interestingly, it has also been demonstrated that SA-MIPs could specifically target cancer cells over normal cells, and that the addition of SA could compete out the SA-MIP binding to the cancer cells [26,34]. These results support our observations using the SA-derivatives, although we cannot completely reduce the binding to SA-expressing cells.

The majority of breast cancers carry Tn (GalNAc-Ser/Thr) within the same cell and in close proximity to extended glycan T (GalB1,3GalNAc), the addition of Gal to the GalNAc being catalyzed by the $T$ synthase [35]. In breast cancer, there can also be a change in the number of O-GalNAc glycans added to the peptide core of glycoproteins, as well as changes in the core structures, which often results in increased sialylation. The sialylated derivatives of the O-GalNAc glycans are commonly observed, giving the sialylated Tn (STn) and sialylated core 1 (ST) glycans [29]. Truncated mucin-type O-linked glycans areseen often terminating in SA due to the up-regulation of sialyltransferases in breast cancers. The altered expression of the sialyltransferase is believed to be the main STn synthase [36]. However, novel diagnostic tools with better affinity and specificity are 
needed. It has been shown that more than $90 \%$ of isolated CTC metastatic bladder and colorectal cancers can overexpress the STn antigen, which is significantly higher than EpCAM-based detection [37]. Recently, Kaptan et al. presented the effect of $\alpha-2,3$ and $\alpha-2,6$ on the cell proliferation, survival, and malignant behaviors of thyroid cancer cells. The authors treated the cancer cells with different plant lectins such as MALII, SNA, and Aleuria aurantia lectin (AAL) [38]. These results suggest that altered cell surface glycosylation in cancer seems to be a strong candidate for new therapeutic strategies.

In this study, we provide a discovery strategy in breast cancer cell lines to understand the binding pattern of lectins and MIPs targeting SA.

\section{Conclusions}

SA expression correlates with EpCAM and inversely with CD44 expression levels on a collection of breast cancer cell lines. SA expression could be detected, both with SA-MIPs and the lectins MAL I and SNA. Most interestingly, two different SA-derivatives used for the first time in this type of assay could significantly reduce the binding of the SA-MIPs in a concentration-dependent manner. This indicates that the SA-MIP binding to cells is mediated by direct interaction with SA. Indeed, we show that the SA-MIPs can function as an additional tool for detecting EpCAM-positive breast cancer cells. In conclusion, we show a combination of potential diagnostic cancer biomarkers that can be used to detect breast epithelial tumor cells that express SA. Further studies using cells from other tissue, including skin and colon, will reveal even novel SA-MIP staining patterns.

Author Contributions: A.G.W. and Z.E.-S. conceived and designed the study. Z.E.-S., Y.Z., and T.G. carried out the cell based studies and performed experiments; S.S., E.J., and R.C. synthesized the chemical compounds; Z.E.-S., B.S., N.D., J.L.P., M.E., R.C., and A.G.W. analyzed the data; B.S. and J.L.P. provided advice and technical assistance; Z.E.-S., Y.Z., and A.G.W. wrote the manuscript. All authors have read and agreed to the published version of the manuscript.

Funding: This research was funded by the Swedish Knowledge Foundation, grant number 20160165; the European Union's Horizon 2020 research and innovation program under the Marie SklodowskaCurie grant agreement, grant number 721297; and the Royal Physiographic Society of Lund, Biofilms Research Center for Biointerfaces and Malmö University.

Institutional Review Board Statement: Not applicable.

Informed Consent Statement: Not applicable.

Data Availability Statement: The datasets during and/or analyzed during the current study available from the corresponding author on reasonable request.

Acknowledgments: The authors would like to thank Bo Holmqvist and Anders Brinte at ImaGene-iT, Lund, Sweden; Karin von Wachenfeldt, Truly Translational AB, Sweden; and Kersti Alm and Birgit Janicke, PHIAB, Sweden.

Conflicts of Interest: The authors declare no conflict of interest.

\section{References}

1. Howlander, N.; Noone, A.; Krapcho, M. SEER Cancer Statistics Review (CSR) 1975-2016. National Cancer Institute Website. Available online: https:/ / seer.cancer.gov/csr/1975_2016/ (accessed on 15 December 2019).

2. Holliday, D.L.; Speirs, V. Choosing the right cell line for breast cancer research. Breast Cancer Res. 2011, 13, 215. [CrossRef]

3. Perou, C.M.; Jeffrey, S.S.; Van De Rijn, M.; Rees, C.A.; Eisen, M.B.; Ross, D.T.; Pergamenschikov, A.; Williams, C.F.; Zhu, S.X.; Lee, J.C. Distinctive gene expression patterns in human mammary epithelial cells and breast cancers. Proc. Natl. Acad. Sci. USA 1999, 96, 9212-9217. [CrossRef]

4. Zhu, Y.; Liu, R.; Huang, H.; Zhu, Q. Vinblastine-Loaded Nanoparticles with Enhanced Tumor-Targeting Efficiency and Decreasing Toxicity: Developed by One-Step Molecular Imprinting Process. Mol. Pharm. 2019, 16, 2675-2689. [CrossRef]

5. Pecot, C.V.; Bischoff, F.Z.; Mayer, J.A.; Wong, K.L.; Pham, T.; Bottsford-Miller, J.; Stone, R.L.; Lin, Y.G.; Jaladurgam, P.; Roh, J.W.; et al. A novel platform for detection of $\mathrm{CK}^{+}$and $\mathrm{CK}^{-}$CTCs. Cancer Discov. 2011, 1, 580-586. [CrossRef]

6. Van der Gun, B.T.F.; Melchers, L.J.; Ruiters, M.H.J.; de Leij, L.F.M.H.; McLaughlin, P.M.J.; Rots, M.G. EpCAM in carcinogenesis: The good, the bad or the ugly. Carcinogenesis 2010, 31, 1913-1921. [CrossRef] [PubMed] 
7. Varki, A.; Lowe, J.B. Biological Roles of Glycans. In Essentials of Glycobiology, 2nd ed.; Varki, A., Cummings, R.D., Esko, J.D., Freeze, H.H., Stanley, P., Bertozzi, C.R., Hart, G.W., Etzler, M.E., Eds.; The Consortium of Glycobiology: La Jolla, CA, USA; Cold Spring Harbor, NY, USA, 2009.

8. Stowell, S.R.; Ju, T.; Cummings, R.D. Protein glycosylation in cancer. Annu. Rev. Pathol. 2015, 10, 473-510. [CrossRef]

9. Ulloa, F.; Real, F.X. Differential distribution of sialic acid in alpha2,3 and alpha2,6 linkages in the apical membrane of cultured epithelial cells and tissues. J. Histochem. Cytochem. 2001, 49, 501-510. [CrossRef]

10. Bogenrieder, T.; Herlyn, M. Axis of evil: Molecular mechanisms of cancer metastasis. Oncogene 2003, 22, 6524-6536. [CrossRef] [PubMed]

11. Büll, C.; Stoel, M.A.; den Brok, M.H.; Adema, G.J. Sialic acids sweeten a tumor's life. Cancer Res. 2014, 74, 3199-3204. [CrossRef] [PubMed]

12. Swindall, A.F.; Londono-Joshi, A.I.; Schultz, M.J.; Fineberg, N.; Buchsbaum, D.J.; Bellis, S.L. ST6Gal-I protein expression is upregulated in human epithelial tumors and correlates with stem cell markers in normal tissues and colon cancer cell lines. Cancer Res. 2013, 73, 2368-2378. [CrossRef] [PubMed]

13. Harduin-Lepers, A.; Krzewinski-Recchi, M.A.; Colomb, F.; Foulquier, F.; Groux-Degroote, S.; Delannoy, P. Sialyltransferases functions in cancers. Front. Biosci. 2012, 4, 499-515. [CrossRef]

14. Loureiro, L.R.; Carrascal, M.A.; Barbas, A.; Ramalho, J.S.; Novo, C.; Delannoy, P.; Videira, P.A. Challenges in antibody development against Tn and Sialyl-Tn antigens. Biomolecules 2015, 5, 1783-1809. [CrossRef] [PubMed]

15. El-Schich, Z.; Zhang, Y.; Feith, M.; Beyer, S.; Sternbæk, L.; Ohlsson, L.; Stollenwerk, M.; Wingren, A.G. Molecularly imprinted polymers in biological applications. BioTechniques 2020, 69, 406-419. [CrossRef] [PubMed]

16. Haupt, K.; Medina Rangel, P.X.; Bui, B.T.S. Molecularly imprinted polymers: Antibody mimics for Bioimaging and therapy. Chem. Rev. 2020, 120, 9554-9582. [CrossRef]

17. Piletsky, S.; Canfarotta, F.; Poma, A.; Bossi, A.M.; Piletsky, S. Molecularly imprinted polymers for cell recognition. Trends Biotechnol. 2020, 38, 368-387. [CrossRef] [PubMed]

18. Wulff, G. Molecular imprinting in cross-linked materials with the aid of molecular templates-a way towards artificial antibodies Angew. Chem. Int. Ed. Engl. 1995, 34, 1812-1832. [CrossRef]

19. Wulff, G.; Sarhan, A.; Zabrocki, K. Enzyme-analogue built polymers and their use for the resolution of racemates. Tetrahedron Lett. 1973, 14, 4329-4332. [CrossRef]

20. Shinde, S.; El-Schich, Z.; Malakpour, A.; Wan, W.; Dizeyi, N.; Mohammadi, R.; Rurack, K.; Gjorloff Wingren, A.; Sellergren, B. Sialic Acid-Imprinted Fluorescent Core-Shell Particles for Selective Labeling of Cell Surface Glycans. J. Am. Chem. Soc. 2015, 137, 13908-13912. [CrossRef]

21. El-Schich, Z.; Abdullah, M.; Shinde, S.; Dizeyi, N.; Rosén, A.; Sellergren, B.; Wingren, A.G. Different expression levels of glycans on leukemic cells-a novel screening method with molecularly imprinted polymers (MIP) targeting sialic acid. Tumor Biol. 2016, 37, 13763-13768. [CrossRef]

22. Panagiotopoulou, M.; Kunath, S.; Medina-Rangel, P.X.; Haupt, K.; Bui, B.T.S. Fluorescent molecularly imprinted polymers as plastic antibodies for selective labeling and imaging of hyaluronan and sialic acid on fixed and living cells. Biosens. Bioelectron. 2017, 88, 85-93. [CrossRef]

23. Bie, Z.; Chen, Y.; Ye, J.; Wang, S.; Liu, Z. Boronate-affinity glycan-oriented surface imprinting: A new strategy to mimic lectins for the recognition of an intact glycoprotein and its characteristic fragments. Angew. Chem. Int. Ed. 2015, 54, 10211-10215. [CrossRef] [PubMed]

24. Xing, R.; Wang, S.; Bie, Z.; He, H.; Liu, Z. Preparation of molecularly imprinted polymers specific to glycoproteins, glycans and monosaccharides via boronate affinity controllable-oriented surface imprinting. Nat. Protoc. 2017, 12, 964-987. [CrossRef] [PubMed]

25. Liu, R.; Cui, Q.; Wang, C.; Wang, X.; Yang, Y.; Li, L. Preparation of sialic acid-imprinted fluorescent conjugated nanoparticles and their application for targeted cancer cell imaging. ACS Appl. Mater. Interfaces 2017, 9, 3006-3015. [CrossRef]

26. Wang, S.; Yin, D.; Wang, W.; Shen, X.; Zhu, J.-J.; Chen, H.-Y.; Liu, Z. Targeting and imaging of cancer cells via monosaccharideimprinted fluorescent nanoparticles. Sci. Rep. 2016, 6, 22757. [CrossRef] [PubMed]

27. Panagiotopoulou, M.; Salinas, Y.; Beyazit, S.; Kunath, S.; Duma, L.; Prost, E.; Mayes, A.G.; Resmini, M.; Tse Sum Bui, B.; Haupt, K. Molecularly Imprinted Polymer Coated Quantum Dots for Multiplexed Cell Targeting and Imaging. Angew. Chem. Int. Ed. Engl. 2016, 55, 8244-8248. [CrossRef] [PubMed]

28. Johansson, E.; Caraballo, R.; Mistry, N.; Zocher, G.; Qian, W.; Andersson, C.D.; Hurdiss, D.L.; Chandra, N.; Thompson, R.; Frängsmyr, L. Pentavalent Sialic Acid Conjugates Block Coxsackievirus A24 Variant and Human Adenovirus Type 37-Viruses That Cause Highly Contagious Eye Infections. ACS Chem. Biol. 2020, 26, 2683-2691. [CrossRef]

29. Burchell, J.M.; Beatson, R.; Graham, R.; Taylor-Papadimitriou, J.; Tajadura-Ortega, V. O-linked mucin-type glycosylation in breast cancer. Biochem. Soc. Trans. 2018, 46, 779-788. [CrossRef]

30. Liu, X.; Yang, L.; Zhang, D.; Liu, T.; Yan, Q.; Yang, X. Deglycosylation of epithelial cell adhesion molecule affects epithelial to mesenchymal transition in breast cancer cells. J. Cell. Physiol. 2019, 234, 4504-4514. [CrossRef]

31. Kölbl, A.; Jeschke, U.; Andergassen, U. The significance of epithelial-to-mesenchymal transition for circulating tumor cells. Int. J. Mol. Sci. 2016, 17, 1308. [CrossRef] 
32. Baccelli, I.; Schneeweiss, A.; Riethdorf, S.; Stenzinger, A.; Schillert, A.; Vogel, V.; Klein, C.; Saini, M.; Bäuerle, T.; Wallwiener, M. Identification of a population of blood circulating tumor cells from breast cancer patients that initiates metastasis in a xenograft assay. Nat. Biotechnol. 2013, 31, 539. [CrossRef]

33. Jing, X.; Cui, X.; Liang, H.; Hao, C.; Yang, Z.; Li, X.; Yang, X.; Han, C. CD24 is a potential biomarker for prognosis in human breast carcinoma. Cell. Physiol. Biochem. 2018, 48, 111-119. [CrossRef] [PubMed]

34. Yin, D.; Wang, S.; He, Y.; Liu, J.; Zhou, M.; Ouyang, J.; Liu, B.; Chen, H.-Y.; Liu, Z. Surface-enhanced Raman scattering imaging of cancer cells and tissues via sialic acid-imprinted nanotags. Chem. Commun. 2015, 51, 17696-17699. [CrossRef] [PubMed]

35. Beatson, R.; Maurstad, G.; Picco, G.; Arulappu, A.; Coleman, J.; Wandell, H.H.; Clausen, H.; Mandel, U.; Taylor-Papadimitriou, J.; Sletmoen, M. The breast cancer-associated glycoforms of MUC1, MUC1-Tn and sialyl-Tn, are expressed in COSMC wild-type cells and bind the C-type lectin MGL. PLoS ONE 2015, 10, e0125994. [CrossRef]

36. Marcos, N.T.; Bennett, E.P.; Gomes, J.; Magalhaes, A.; Gomes, C.; David, L.; Dar, I.; Jeanneau, C.; DeFrees, S.; Krustrup, D. ST6GalNAc-I controls expression of sialyl-Tn antigen in gastrointestinal tissues. Front. Biosci. 2011, 3, 1443-1455. [CrossRef]

37. Neves, A.A.; Stockmann, H.; Harmston, R.R.; Pryor, H.J.; Alam, I.S.; Ireland-Zecchini, H.; Lewis, D.Y.; Lyons, S.K.; Leeper, F.J.; Brindle, K.M. Imaging sialylated tumor cell glycans in vivo. FASEB J. Off. Publ. Fed. Am. Soc. Exp. Biol. 2011, 25, 2528-2537. [CrossRef]

38. Kaptan, E.; Sancar-Bas, S.; Sancakli, A.; Bektas, S.; Bolkent, S. The effect of plant lectins on the survival and malignant behaviors of thyroid cancer cells. J. Cell. Biochem. 2018, 119, 6274-6287. [CrossRef] [PubMed] 
II 



\section{Improved biomarker detection analysis of}

\section{glycosylated cell surface structures using sialic acid- targeted fluorescent core-shell particles}

Sarah Beyer ${ }^{1,2 \dagger}$, Martha Kimani ${ }^{3 \dagger}$, Yuecheng Zhang ${ }^{1,2}$, Alejandra Verhassel ${ }^{4}$, Louise Sternbæk $^{1,2,5}$, Tianyan Wang ${ }^{6}$, Jenny L. Persson ${ }^{1,2,6}$, Pirkko Härkönen ${ }^{4}$, Emil Johansson ${ }^{7,8}$, Remi Caraballo $^{7,8}$, Mikael Elofsson ${ }^{7,8}$, Kornelia Gawlitza ${ }^{3}$, Knut Rurack $^{3}$, Lars Ohlsson ${ }^{1,2}$, Zahra ElSchich $^{1,2}$, Anette Gjörloff Wingren ${ }^{1,2}$, Maria M. Stollenwerk ${ }^{1,2^{*}}$

1) Department of Biomedical Sciences, Faculty of Health and Society, Malmö University, Malmö, Sweden

2) Biofilms-Research Center for Biointerfaces, Malmö University, Malmö, Sweden

3) Bundesanstalt für Materialforschung und -prüfung (BAM), Berlin, Germany

4) Institute of Biomedicine, University of Turku, Turku, Finland

5) Phase Holographic Imaging AB, Lund, Sweden

6) Department of Molecular Biology, Umeå University, Umeå, Sweden

7) Department of Chemistry, Umeå University, Umeå, Sweden

8) Umeå Centre for Microbial Research, Umeå University, Umeå, Sweden

$\dagger$ Both authors contributed equally to this manuscript

Corresponding author: Maria M. Stollenwerk (maria.stollenwerk@mau.se) 


\begin{abstract}
Sialic acid (SA) is a monosaccharide usually linked to the terminal of glycan chains on the cell surface. It plays crucial roles in many biological processes and hypersialylation is a common feature in cancer. To analyze the cell surface expression of SA, lectins are widely used. However, these protein molecules are usually expensive and easy to denature, which calls for the development of alternative glycan-specific receptors and cell imaging technologies. In this study, fluorescent core-shell molecularly imprinted polymer particles imprinted with SA (SA-MIPs) were employed to recognize SA on the cell surface of cancer cell lines. The binding pattern of SA-MIPs was compared with the staining results of the two lectins Maackia Amurensis Lectin I (MAL I, $\alpha 2,3 \mathrm{SA}$ ) and Sambucus Nigra Lectin (SNA, $\alpha 2,6 \mathrm{SA}$ ). The results show that the selected cancer cell lines in this study present varied expression of $\alpha 2,3$ and $\alpha 2,6 \mathrm{SA}$, and thus show different binding behavior to SA-MIPs. Moreover, two pentavalent SA conjugates were used for binding inhibition of the SA-MIPs to the cancer cell lines, demonstrating the specificity of the SA-MIPs. We conclude that the synthesized SA-MIPs could be a powerful tool in the diagnostic analysis of cancer cells.
\end{abstract}

Keywords: Cancer; Imprinting; Molecularly imprinted polymers; SA conjugates; Sialic acid 


\section{Introduction}

Sialic acid (SA) is a nine-carbon monosaccharide, which is located at the terminal of cell surface proteins, lipids, or secreted proteins [1]. SA can be linked to the C-6 position of $\mathrm{N}$ acetylgalactosamine (GalNAc), to the C-6 or C-3 positions of galactose (Gal), or to the C-8 or C9 positions of another SA [2]. SA plays a critical role in many normal physiological and pathological processes, e.g. the repulse of cell-cell interaction, and serves as a binding site for different toxins, pathogens and glycan-binding proteins [1].

The level of SA expression is increased in cancer, which has been shown to result in increased metastatic and invasive potential of the cancer cell [3]. Traditionally, SA expression has been analyzed by using lectins such as Maackia Amurensis Lectin I (MAL I) and Sambucus Nigra Lectin (SNA), and by antibodies targeting SA [4]. However, specific targeting of glycosylated proteins is challenging since the availability of adequate lectins and glycan-specific antibodies is limited [5]. The specificity and affinity of the lectins and antibodies are usually not sufficient. This calls for the development of alternative glycan-specific receptors and cell imaging technologies.

Molecularly imprinted polymers (MIPs) are polymers in which a target template is incorporated in the polymerization process, such that template removal after synthesis leaves cavities in the polymer matrix with high affinity and specificity to the target molecule $[6,7]$. Being of nonbiological origin, engineered MIPs are extremely robust, resist denaturing solvents, are stable at high temperatures, and can be reproduced at low cost [8]. Indeed, MIPs have been successfully applied as artificial recognition elements in targeting glycans such as SA and glycosaminoglycans (GAGs) [7]. Boronic-acid-based semi-covalent imprinting is widely used to recognize glycoproteins since they can bind reversibly with cis-diol groups of the saccharide units. We and others have used monosaccharide SA as a template and developed core-shell SA-imprinted particles with defined size, which could be further applied as imaging agents for cell surface glycans [9-14]. We have previously reported the use of nitrobenzoxadiazole (NBD) fluorochrome as reporter group and SA as an imprinted template on the surface of silica beads of approximately $200 \mathrm{~nm}[7,9,14-17]$. 
In this study, we utilized SA-MIPs synthesized on silica-coated polystyrene particles (ca. $170 \mathrm{~nm}$ ) as cell staining agents. We recently reported on the synthesis and binding properties of these particles in solution and in cell labelling assays with two cancer cell lines [14]. Compared to previous works, a polystyrene core provides a lighter, lower-density support for improved suspensibility and scattering properties. The specificity of the particles was evaluated by comparing the binding performance of SA-MIPs with that of conventional non-imprinted polymer (NIP) control particles as well as "dummy" NIPs prepared with a "dummy" template [14]. Here, we analyzed the SA expression on thirteen different cancer cell lines using the SA-MIPs and the two lectins MAL I and SNA by flow cytometry and confocal fluorescence microscopy. The results show that the different cancer cell lines show varied expression of $\alpha 2,3$ and $\alpha 2,6 \mathrm{SA}$, and thus display different binding behavior to SA-MIPs.

In addition, the specificity of the MIPs was determined by an inhibition assay using pentavalent SA conjugates, ME0752 and ME0976 [18, 19]. By pre-treating the SA-MIPs with different concentrations of the two SA conjugates prior to cell staining, we observed a reduction in SA-MIP binding to the cells, confirming the selectivity of the MIPs for SA on the cell surface. Our results showed the potential of applying SA-MIPs in the testing of complex biological samples. We conclude that the synthesized SA-MIPs could be a powerful tool in the diagnostic analysis of cancer cells.

\section{Experiment and Methods}

\section{Reagents and cell culture}

The biotin labeled lectin MAL I and SNA were purchased from Vector Laboratories. The streptavidin-FITC was obtained from Agilent Technologies. The Falcon multi-chamber culture glass slides were purchased from Corning. Mounting medium ProlongQR Gold antifade reagent was purchased from Molecular probes. Phosphate buffered saline (PBS) and DAPI were brought from Thermo Fisher Scientific and Triton 100X and rhodamine phalloidin were purchased from Sigma-Aldrich. Human cell lines including SK-BR-3, MDA-MB-468, PC-3, THP-1, Jurkat, A431, MCF7, MDA-MB-231, A549, CAMA-1, T-47D, and Hs 578T were obtained from American 
Type Culture Collection (ATCC). Hek-n cells are primary human epidermal keratinocytes isolated from neonatal foreskinand were purchased from Thermo Fisher Scientific. The following cells were cultured in cell culture medium purchased from Thermo Fisher Scientific: MDA-MB-231 and MDA-MB-468 cells were cultured in Dulbecco's Modified Eagle Medium (DMEM) supplemented with $10 \%$ fetal bovine serum (FBS). MCF7, Jurkat, THP-1 and T-47D cells were cultured in RPMI-1640 medium supplemented with $10 \%$ FBS and $50 \mu \mathrm{g} / \mathrm{mL}$ gentamycin. Hs$578 \mathrm{~T}$ cells were cultured in DMEM supplemented with $10 \%$ FBS, $1 \%$ penicillin-streptomycin (PEST) and $10 \mu \mathrm{g} / \mathrm{mL}$ insulin. CAMA-1 was cultured in RPMI-1640 medium supplemented with $10 \% \mathrm{FBS}, 1 \%$ PEST and $1 \%$ sodium pyruvate. A549 cells were cultured in RPMI-1640 medium supplemented with $10 \%$ FBS and $1 \%$ PEST. SK-BR-3 and PC-3 were cultured in DMEM supplemented with 10\% FBS, 1\% GlutaMAX (Life Technologies) and 1\% PEST. Hek-n cells were maintained in EpiLife growth medium with $60 \mathrm{mM}$ calcium chloride supplemented with $1 \%$ of human keratinocyte growth supplement (HKGS) and $0.2 \%$ gentamycin/amphotericin. A-431 were cultured in Eagle's Minimum Essential Medium (EMEM, Sigma-Aldrich) supplemented with 10\% FBS, $1 \%$ L-Glutamine (Thermo Fisher Scientific) and $1 \%$ Non-Essential Amino Acids (Thermo Fisher Scientific). All the cell lines were cultured at $37{ }^{\circ} \mathrm{C}$ with $5 \% \mathrm{CO}_{2}$ in $100 \%$ humidity.

\section{SA-MIP synthesis}

The MIPs synthesis was performed as we recently reported [14].

\section{Flow cytometry assay for lectin staining}

Briefly, the cells were first washed twice with $2 \mathrm{~mL}$ PBS. Next, the cells were divided into several flow cytometry tubes $\left(5 \times 10^{5}\right.$ cells per sample) and a $100 \mu \mathrm{L}$ mixture of cells, $5 \mu \mathrm{g} / \mathrm{mL}$ lectins and PBS were incubated in the dark at $4{ }^{\circ} \mathrm{C}$ for $30 \mathrm{~min}$. These samples were washed twice with $1.5 \mathrm{~mL}$ PBS followed by staining with $10 \mu \mathrm{g} / \mathrm{mL}$ of streptavidin-FITC in the dark at $4{ }^{\circ} \mathrm{C}$ for 20 min. After incubation, the cells were again washed twice and resuspended in $300 \mu \mathrm{L}$ PBS. for flow cytometric analysis (BD Biosciences, Accuri C6 Flow Cytometry, NJ, USA). The flow cytometric analysis was carried out on the BD Biosciences, Accuri C6 Flow Cytometry (NJ, USA) with a 488 
$\mathrm{nm}$ excitation laser coupled to a 530/30 nm BP filter. A total of 10,000 events was captured in the gate and used for the SA-expression analysis.

\section{Flow cytometry assay for MIPs staining}

$1 \times 10^{6}$ cells per sample were stained with SA-MIPs. The cells were washed twice with $2 \mathrm{~mL}$ PBS and thereafter divided into several flow cytometry tubes and incubated with SA-MIPs $(0.1 \mathrm{mg} / \mathrm{mL})$ in $100 \mu \mathrm{L}$ PBS at $4{ }^{\circ} \mathrm{C}$ for $30 \mathrm{~min}$ in the dark. After incubation, the cells were washed twice and resuspended in $300 \mu \mathrm{L}$ PBS for flow cytometric analysis. A total of 10,000 events was captured in the gate and used for the SA-expression analysis.

\section{Pre-treatment of SA-MIPs with SA conjugates}

In this assay, the SA-MIPs were pre-treated with pentavalent SA conjugates before they were used in a MIP staining assay according to the experimental procedure described above. Pre-treatment was carried out by pre-incubating the MIP solution with different concentrations ( 20 and $200 \mu \mathrm{M})$ of the SA conjugates ME0976 or ME0752 at room temperature for $5 \mathrm{~min}$.

\section{Confocal fluorescence microscopy analysis}

For the confocal fluorescence microscopy analysis, $1 \times 10^{5}$ cells/well were seeded in a Falcon multi-chamber culture glass slide with a final volume of $500 \mu \mathrm{L}$ and incubated for $48 \mathrm{~h}$ in $37{ }^{\circ} \mathrm{C}$ with $5 \% \mathrm{CO} 2$ in $100 \%$ humidity. The cells were washed in PBS and fixed with $100 \mu \mathrm{L} 4 \%$ formaldehyde (Sigma-Aldrich) at room temperature for $10 \mathrm{~min}$ followed by washing twice with PBS and once with $0.05 \%$ Triton 100X in PBS. Afterwards, the cells were permeabilized and stained with $100 \mu \mathrm{L}$ of $1 / 100$ diluted rhodamine phalloidin for $30 \mathrm{~min}$ in the dark at room temperature. After washing twice with $0.05 \%$ Triton $100 \mathrm{X}$ in PBS and twice with PBS, the samples were incubated with $100 \mu \mathrm{L}$ SA-MIPs $(0.1 \mathrm{mg} / \mathrm{ml})$, that were either untreated or pretreated with $200 \mu \mathrm{M}$ SA conjugates, for $30 \mathrm{~min}$ in the dark at room temperature. The samples were further washed four times with PBS and stained with $300 \mathrm{nM}$ DAPI in the dark for 4 min at room temperature. After another two washes with PBS, the samples were mounted with one drop of mounting medium ProlongQR Gold antifade reagent and stored at $4{ }^{\circ} \mathrm{C}$ before analysis by confocal fluorescence microscopy (Nikon Instruments A1R HD25, Melville, NY, USA). 


\section{Results}

SA staining with lectins MAL I and SNA on a variety of cancer cell lines

In this study, two different lectins, MAL I ( $\alpha 2,3-\mathrm{SA})$ and SNA ( $\alpha 2,6-\mathrm{SA})$, were used to analyze the expression of SA on the surface of thirteen human cancer cell lines by flow cytometry: SKBR-3, MDA-MB-468, PC-3, THP-1, Jurkat, A-431, MCF7, MDA-MB-231, A549, Hek-n, CAMA-1, T-47D, and Hs 578T cells. The values of the $\alpha 2,3-\mathrm{SA}$ and $\alpha 2,6-\mathrm{SA}$ lectin staining are presented as the mean fluorescence intensity (MFI) (Table 1) and in histograms (Figure 1). The background MFI is also shown for each cell line in Figure 1 (black line). The breast cancer cell line CAMA-1 shows the lowest expression of $\alpha 2,3-\mathrm{SA}$. For $\alpha 2,6-\mathrm{SA}$ expression, the breast cancer cell line MCF7 and prostate cell line PC-3 show the least pronounced expression (Table 1). High expression levels of $\alpha 2,3-\mathrm{SA}$ were determined in breast cancer cell lines Hs 578T and MDA-MB231 and the lung carcinoma cell line A549 (Table 1). The experiment has been repeated twice and the results shows small deviation. Therefore, one representative experiment out of two performed is shown. The MFI values of $\alpha 2,3-\mathrm{SA}$ and $\alpha 2,6-\mathrm{SA}$ staining results are also displayed in bar diagrams (Figure 2A and B) to facilitate the comparison with SA-MIP MFI values (Figure 3B).

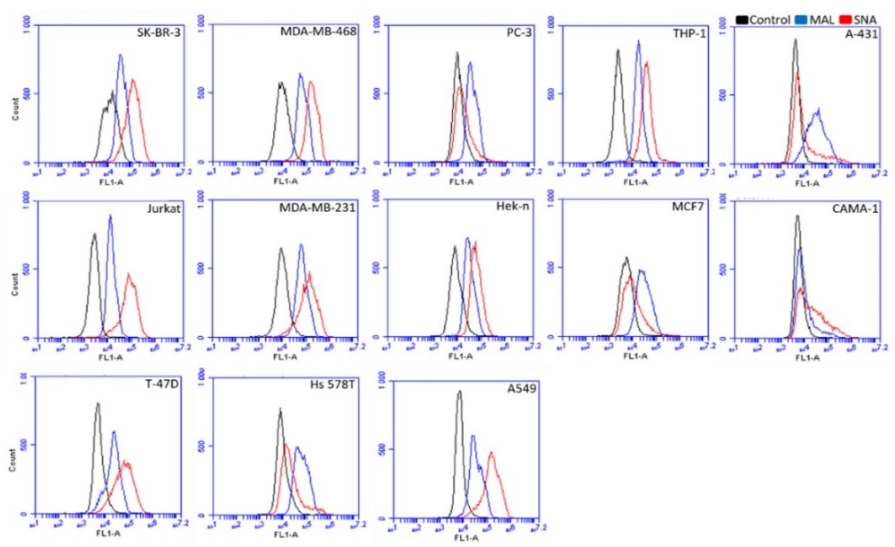

Figure 1: MAL I ( $\alpha 2,3 \mathrm{SA})$ and SNA ( $\alpha 2,6 \mathrm{SA})$ lectin binding to thirteen cell lines. Both lectins were used at a concentration of $5 \mu \mathrm{g} / \mathrm{mL}$. The flow cytometry histograms show the mean fluorescence intensity (MFI) of unstained control cells (black lines) and lectin stained cells (blue lines for MAL I and red lines for SNA). One representative experiment out of two performed is shown. 
Table 1: MAL I and SNA expression, presented as mean fluorescence intensity (MFI) on selected cancer cell lines.

\begin{tabular}{|c|c|c|c|}
\hline & MAL & SNA & SA-MIPs \\
\hline SK-BR-3 & 41004 & 131978 & 24428 \\
\hline MDA-MB-468 & 58797 & 186916 & 43541 \\
\hline PC-3 & 43634 & 23796 & 45232 \\
\hline THP-1 & 20480 & 48682 & 46423 \\
\hline A-431 & 47952 & 33574 & 47422 \\
\hline Jurkat & 21384 & 193452 & 73508 \\
\hline MDA-MB-231 & 83974 & 170770 & 94633 \\
\hline Hek-n & 34686 & 79640 & 125189 \\
\hline MCF7 & 55471 & 14251 & 127531 \\
\hline CAMA-1 & 15987 & 52167 & 139479 \\
\hline T-47D & 49544 & 221300 & 158930 \\
\hline Hs 578T & 74543 & 44523 & 312901 \\
\hline A549 & 73340 & 270388 & \\
\hline
\end{tabular}




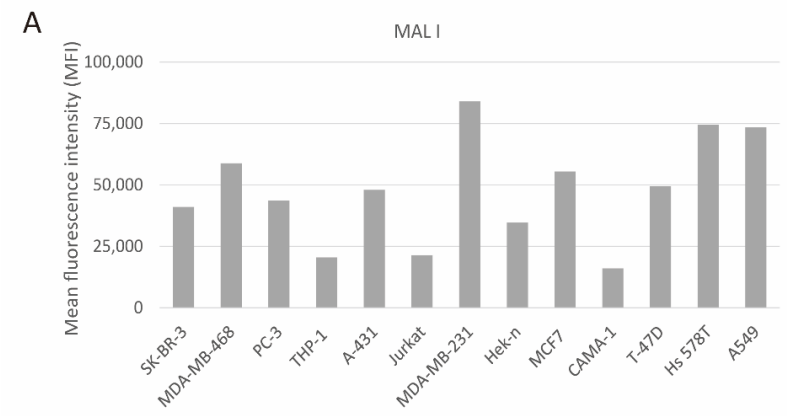

B

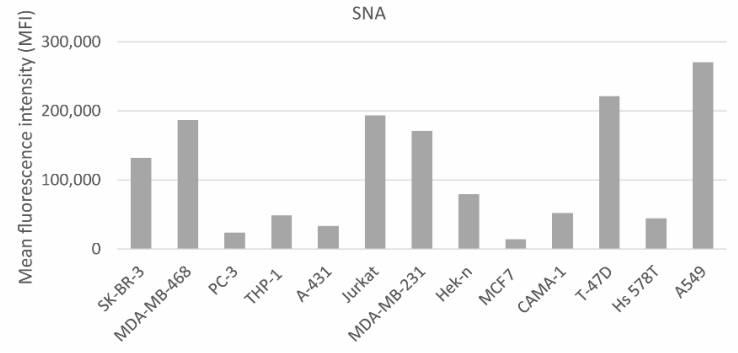

Figure 2: Lectin binding to thirteen cell lines as shown by MFI. Both lectins were used at a concentration of $5 \mu \mathrm{g} / \mathrm{mL}$. A: MAL I ( $\alpha 2,3 \mathrm{SA})$. B: SNA $(\alpha 2,6 \mathrm{SA})$. One representative experiment out of two performed is shown.

\section{The binding pattern of SA-MIPs to several cancer cell lines}

The binding properties of the SA-MIPs were analysed using flow cytometry. The MFI of SA-MIP binding for the cell lines SK-BR-3, MDA-MB-468, PC-3, THP-1, Jurkat, A-431, MCF7, MDAMB-231, A549, Hek-n, CAMA-1, T-47D, and Hs 578T are shown in Table 1 and Figure 3. The SA-MIP binding properties are displayed in histograms (Figure 3A) as well as in bar diagrams showing the MFI (Figure 3B). The order of the cell lines is based on the binding capacity of the SA-MIPs. 
A
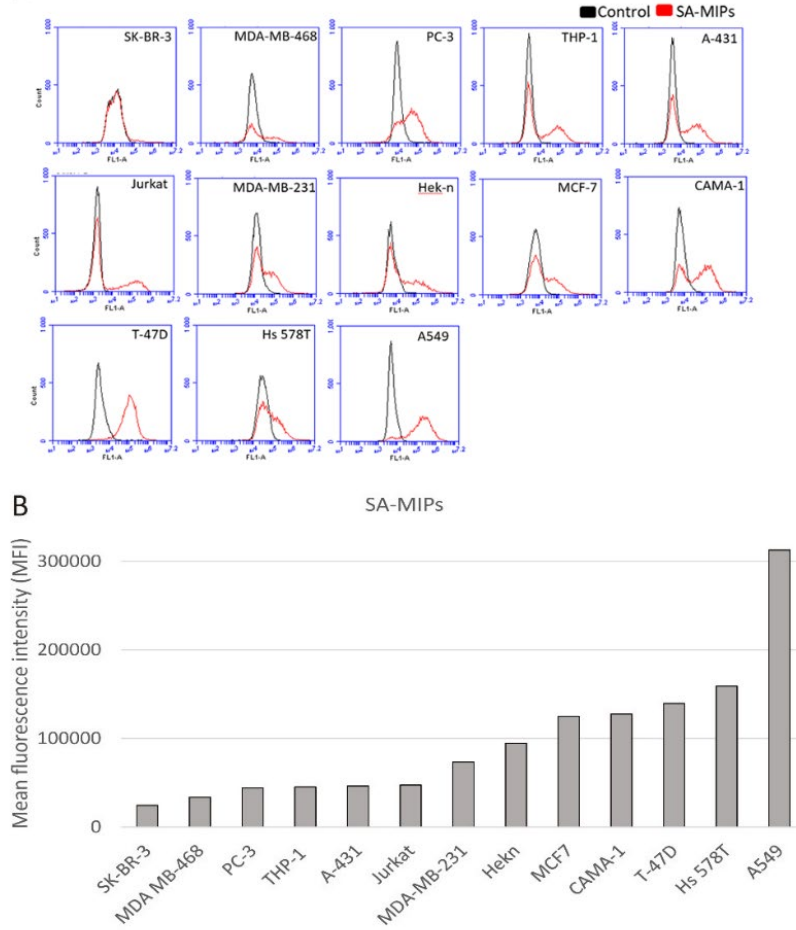

Figure 3: SA-MIP binding to the thirteen cell lines as shown by MFI. The concentration of SA-MIPs is $0.1 \mathrm{mg} / \mathrm{mL}$. A: The flow cytometry histograms show the MFI of unstained control cells (black lines) and SA-MIP stained cells (red lines). B: The bar diagrams show the MFI of SA-MIP stained cells. One representative experiment out of two performed is shown.

\section{Pre-treatment of SA-MIPs with SA conjugates reduce the binding to cancer cell lines}

Three cell lines with different binding properties to SA-MIPs, A549 lung carcinoma cells (high binding), MCF7 breast cell line (average binding) and A-431 skin carcinoma cells (low binding), were selected for further analysis. The specificity of the SA-MIP binding was assessed by using flow cytometry. The SA-MIPs were pre-incubated with SA-derivates ME0752 or ME0976 at either $20 \mu \mathrm{M}$ or $200 \mu \mathrm{M}$ concentration respectively, and then applied in cell binding assays. For all three cell lines, a reduction in MFI was observed for MIP binding to the cells after incubation with both 
concentrations of the SA-derivates (Figure 4). The highest degree of reduction occurred with the skin carcinoma cell line A-431 (Figure 4B).

A

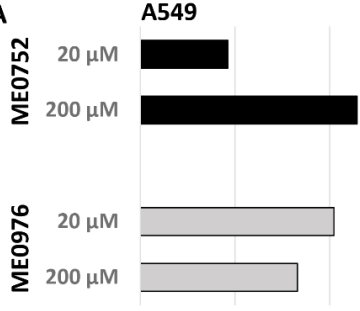

20

40
B

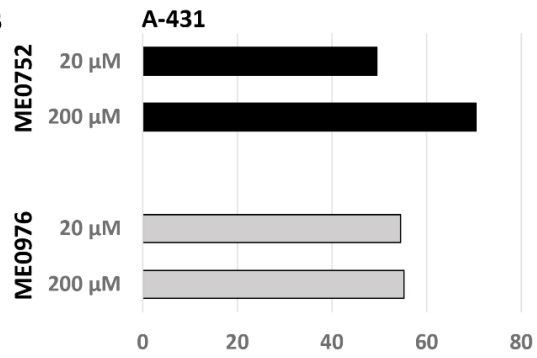

Reduction of binding in \%
C

MCF7

$$
\text { ํํำ }
$$

กิ $20 \mu$

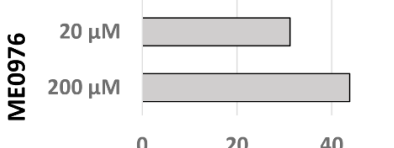

Reduction of binding in \%

80



$60-80$

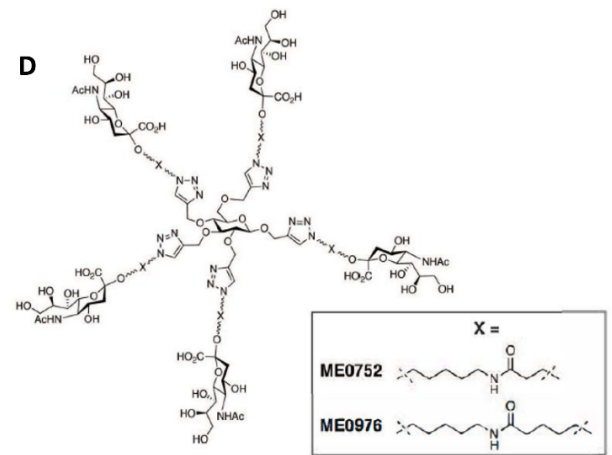

Figure 4: SA-MIPs were pre-incubated with different concentrations of the SA conjugates and analyzed with flow cytometry. The reduction of binding compared to SA-MIP binding alone is shown. The SA conjugates ME0752 and ME0976 were added to the SA-MIPs at $20 \mu \mathrm{M}$ and $200 \mu \mathrm{M}$, respectively and the particles thereafter used to stain (A) A549, (B) A-431 and (C) MCF7 cells. The chemical structures. for ME0752 and ME0976 are shown in (D).

\section{SA-MIPs staining pattern visualized by confocal fluorescence microscopy}

To visualize the binding of the SA-MIPs to the cells, and to characterize the fluorescence properties of the SA-MIPs, the three selected cancer cell lines A549, MCF7 and A-431 were analysed using confocal fluorescence microscopy. In addition to staining with SA-MIPs, all cell lines were stained with DAPI and phalloidin for nuclei and cytoskeleton visualization, respectively. The binding pattern and distribution of the SA-MIPs was shown to be different in the three cell lines. 


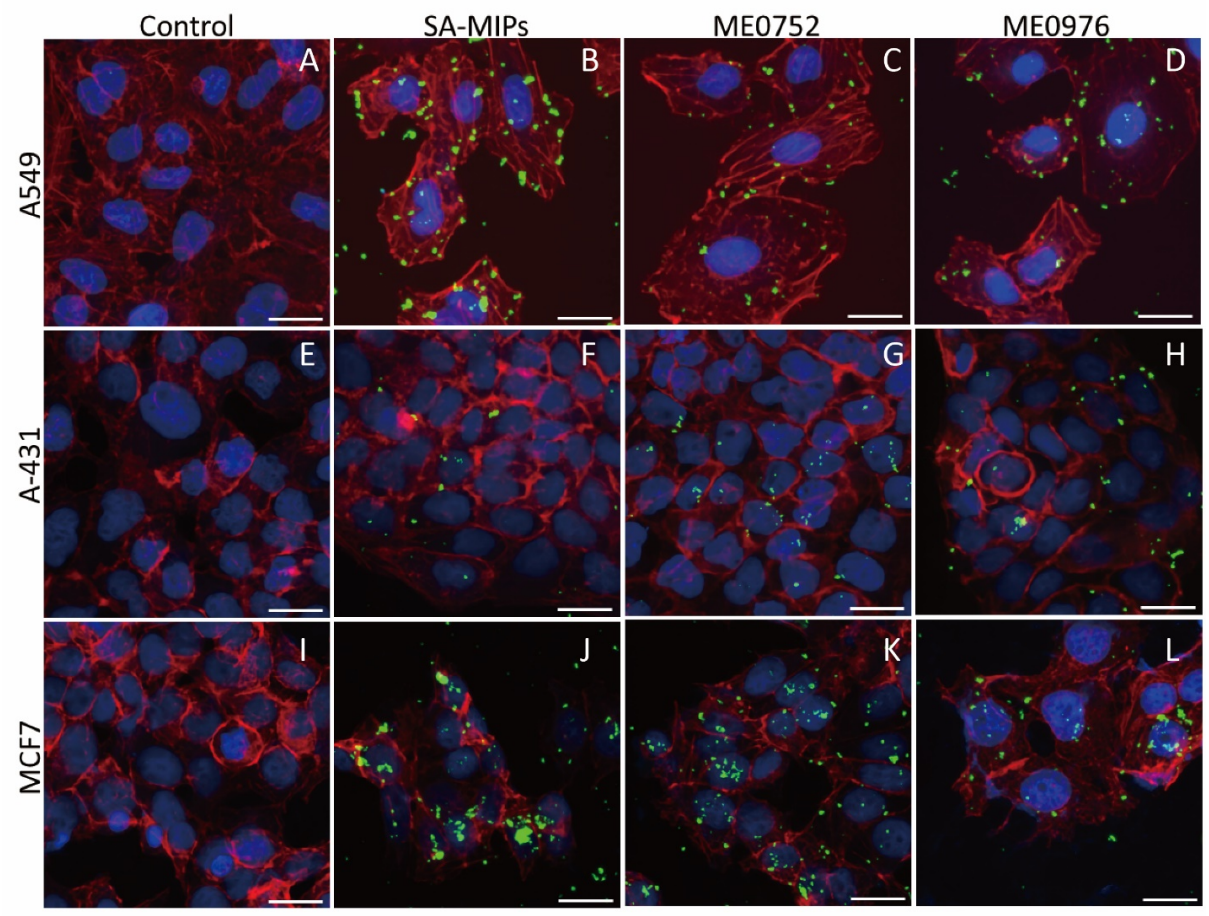

Figure 5: Confocal fluorescence microscopy images of SA-MIPs staining of three different cancer cell lines. A549 (A-D), A-431 (E-H) and MCF7 (I-L) were stained with SA-MIPs (B, F, J) in green, rhodaminephalloidin (actin filaments) in red and DAPI (nuclei) in blue. The two columns on the right show staining with SA-MIPs after pre-treatment of the cells with SA conjugates ME0752 (C, G, K) and ME0976 (D, H, L). Scale bar: $20 \mu \mathrm{m}$.

The A549 cells show a uniform distribution of SA-MIP aggregates (Figure 5B). In contrast, the A-431 cells show a very low binding of the SA-MIPs (Figure 5F), whereas MCF7 cells show a heterogenous SA-MIP binding pattern with both large and smaller aggregates (Figure 5J).

After pre-treatment with $200 \mu \mathrm{M}$ of the ME0752 SA conjugates, the SA-MIP binding pattern changed. Now, the A549 cells show less binding of SA-MIPs, and the aggregates were smaller (Figure 5C). In contrast, A-431 cells show several SA-MIPs bound, as small particles (Figure 5G). MCF7 cells show smaller aggregates, but with similar amounts of particles bound (Figure 5K). 
After pre-treatment with $200 \mu \mathrm{M}$ of the ME0976 SA conjugates, the SA-MIP binding pattern for A549 cells (Figure 5D) and A-431 cells (Figure 5H) is similar to pre-treatment with ME0752. The MCF7 cells show less particles bound compared to those pre-treated using ME0752 (Figure 5L).

\section{Discussion}

We previously reported the use and development of core-shell SA-imprinted particles for determining cell surface glycans [7, 9, 14-17]. Here, we extend the cell surface SA analysis by utilizing core-shell SA-MIPs developed on a silica-coated polystyrene core[14]. We reported that the SA-imprinted MIP particles preferentially bind to SA-expressing cells, displaying binding behavior comparable to that of SA-targeting lectins.

To investigate whether there is a correlation between MAL I and SNA staining and SA-MIP binding on a larger set of cell types, we stained all cell lines that were included in this study with the two lectins and the SA-MIPs and analysed them by flow cytometry. The results show that these cell lines have various $\alpha 2,3$ and $\alpha 2,6$-SA expression. The flow cytometry analysis is performed on cells in suspension, where the cells are detached and rounded-up, whereas most of the epithelial cell types preferably attach to the surface as adherent cells. The organization of membrane proteins differs between the rounded-up and adherence form, which may affect the outcome of glycan staining. In addition, the weak nature of glycan-mediated interactions may affect the MAL I and SNA binding properties, as well as specificity $[5,20]$.

We further developed the use of pentavalent SA conjugates to validate the binding of the SA-MIPs to three different cell types, A549 lung carcinoma, MCF7 breast cancer and A-431 skin carcinoma cells $[18,19]$. The SA conjugates contain flexible spacers capable of binding the SA-MIPs in a concentration-dependent manner and we could show a reduced cell binding after pre-incubating the SA conjugates with the SA-MIPs (Figure 4D). The MFI values were substantially reduced using either conjugates, ME0976 or ME0752. This is because the SA conjugates are bound by the SA-specific sites on the MIP particles, rendering them unavailable to the SA on the cell surface of the cancer cells. This confirms the selectivity of the MIP particles for the binding of SA. We have 
recently demonstrated the novel use of SA conjugates ME1057 and ME0970 by pre-treating the SA-MIPs $(200 \mathrm{~nm})$ with these SA conjugates as inhibitors[21]. Previously synthesized SA conjugates were successfully used to inhibit cell attachment and cell infection in assays with human corneal epithelial cells $[18,19]$. These results together with the results obtained in this study suggest that the SA conjugates represent promising candidates as multivalent inhibitory targets for SA.

The staining pattern of the SA-MIPs was visualized on the selected cancer cell lines, A549, MCF7 and A-431, by using confocal microscopy. The binding pattern to the lung carcinoma A549 cells revealed a uniform distribution of SA-MIP aggregates. Most interestingly, the addition of pentavalent SA conjugates changed the SA-MIP staining pattern of the cells both by diminishing the SA-MIP binding and the size of the aggregates. For all three cell types analyzed, the aggregates were smaller after addition of SA conjugates, but the numbers of bound SA-MIPs were different. A549 cells showed fewer bound particles, whereas MCF7 showed similar numbers. In contrast, the SA-MIPs bound to A-431 cells were increased. The preincubation of SA conjugates with the MIP particles prior to cell binding results in the presence of the spacer molecules on the particle surface, which allows better dispersion of the MIP particles in suspension due to interarticular repulsion which subsequently reduces aggregation.

According to our flow cytometry results showing MFI for all cell lines, $\alpha 2,3-\mathrm{SA}$ on A-431 and MCF7 cells are expressed at comparable levels according to staining with MAL I. For A-431, the confocal microscopy imaging shows very few SA-MIP particles bound to the cell surface. The different distribution of the SA-MIPs on A549, as shown by imaging could be explained with the MAL I and SNA staining results, respectively. The MFI values for MAL I staining were high on all cell lines, whereas only A549 express $\alpha 2,6-$ SA as shown by SNA staining results.

Based on the cell binding assays, the SA-MIPs did not reveal clear specificity for $\alpha 2,3-$ SA or $\alpha 2,6$ SA in comparison to cell staining using lectins. The SA-MIPs are significantly larger than lectins and are expected to display multivalent interactions with the cell surface. Moreover, each cell line 
has distinct characteristics and morphology that could influence the binding behavior of the MIP particles. Cell binding with lectins is therefore necessary for calibration prior to staining using fluorescent MIPs.

\section{Conclusions}

To conclude, we have analyzed the SA expression on thirteen different cancer cell lines using SAMIPs together with MAL I and SNA. The results show that varying expression of $\alpha 2,3$ and $\alpha 2,6$ SA results in different binding capacities of SA-MIPs. Preincubation of the SA-MIPs with pentavalent SA conjugates led to a reduction in the overall binding of the MIPs, pointing to specificity of the MIPs to bind SA. In conclusion, the synthesized SA-MIPs could be applied as effective tools to analyze the potential biomarker SA expressed on the surface of cancer cells.

\section{Author contributions}

SB, YZ, ZE and AGW conceived and designed the study. SB, ZE, YZ, AV, TW, LS and YZ carried out the cell based studies and performed experiments; MK, KG and KR designed and synthesized chemical compounds; ZE, SB, YZ, JLP, MS, LO and AGW analyzed the data; KG, LO, MS, PH and JLP provided advice and technical assistance; SB, ZE, YZ, MS, PH and AGW wrote the manuscript. All authors read and approved the final manuscript.

\section{Funding sources}

This study was funded by the European Union's Horizon 2020 research and innovation program under the Marie Sklodowska-Curie grant agreement number 721297, the Swedish Knowledge Foundation grant number 20160165, the Malmö Cancer Center, Biofilms Research Center for Biointerfaces and Malmö University.

\section{Notes}

The authors declare that they have no competing interests. 


\section{Reference}

[1] A. Varki, Sialic acids in human health and disease, Trends in Molecular Medicine 14(8) (2008) 351-360.

[2] A. Varki, Biological roles of glycans, Glycobiology 27(1) (2017) 3-49.

[3] T. Bogenrieder, M. Herlyn, Axis of evil: molecular mechanisms of cancer metastasis, Oncogene 22(42) (2003) 6524-6536.

[4] R.D. Cummings, A.G. Darvill, M.E. Etzler, M.G. Hahn, Glycan-Recognizing Probes as Tools, in: A. Varki, R.D. Cummings, J.D. Esko, P. Stanley, G.W. Hart, M. Aebi, A.G. Darvill, T. Kinoshita, N.H. Packer, J.H. Prestegard, R.L. Schnaar, P.H. Seeberger (Eds.), Essentials of Glycobiology, Cold Spring Harbor Laboratory Press, Cold Spring Harbor (NY), 2017.

[5] L.R. Loureiro, M.A. Carrascal, A. Barbas, J.S. Ramalho, C. Novo, P. Delannoy, P.A. Videira, Challenges in antibody development against Tn and Sialyl-Tn antigens, Biomolecules 5(3)

(2015) 1783-1809.

[6] B. Sellergren, A.J. Hall, Molecularly Imprinted Polymers, in: J.W. Steed, P.A. Gale (Eds.), Supramolecular Chemistry: From Molecules to Nanomaterials, John Wiley \& Sons, Hoboken (NY), 2012, pp. 3255-3280.

[7] Z. El-Schich, Y. Zhang, M. Feith, S. Beyer, L. Sternbæk, L. Ohlsson, M. Stollenwerk, A. Gjörloff Wingren, Molecularly imprinted polymers in biological applications, BioTechniques 69(6) (2020) 406-419.

[8] A. Hillberg, K. Brain, C. Allender, Molecular imprinted polymer sensors: implications for therapeutics, Advanced Drug Delivery Reviews 57(12) (2005) 1875-1889.

[9] S. Shinde, Z. El-Schich, A. Malakpour, W. Wan, N. Dizeyi, R. Mohammadi, K. Rurack, A. Gjörloff Wingren, B.r. Sellergren, Sialic acid-imprinted fluorescent core-shell particles for selective labeling of cell surface glycans, Journal of the American Chemical Society 137(43) (2015) 13908-13912.

[10] Z. Bie, Y. Chen, J. Ye, S. Wang, Z. Liu, Boronate - affinity glycan - oriented surface imprinting: a new strategy to mimic lectins for the recognition of an intact glycoprotein and its characteristic fragments, Angewandte Chemie International Edition 54(35) (2015) 10211-10215. [11] S. Wang, D. Yin, W. Wang, X. Shen, J.-J. Zhu, H.-Y. Chen, Z. Liu, Targeting and imaging of cancer cells via monosaccharide-imprinted fluorescent nanoparticles, Scientific reports 6(1) (2016) 1-11.

[12] M. Panagiotopoulou, Y. Salinas, S. Beyazit, S. Kunath, L. Duma, E. Prost, A.G. Mayes, M. Resmini, B. Tse Sum Bui, K. Haupt, Molecularly imprinted polymer coated quantum dots for multiplexed cell targeting and imaging, Angewandte Chemie International Edition 55(29) (2016) 8244-8248.

[13] M. Panagiotopoulou, S. Kunath, P.X. Medina-Rangel, K. Haupt, B.T.S. Bui, Fluorescent molecularly imprinted polymers as plastic antibodies for selective labeling and imaging of hyaluronan and sialic acid on fixed and living cells, Biosensors and Bioelectronics 88 (2017) 8593.

[14] M. Kimani, S. Beyer, Z. El-Schich, K. Gawlitza, A. Gjörloff-Wingren, K. Rurack, Imprinted Particles for Direct Fluorescence Detection of Sialic Acid in Polar Media and on Cancer Cells with Enhanced Control of Nonspecific Binding, ACS Applied Polymer Materials 3 (2021) in print.

[15] Z. El-Schich, M. Abdullah, S. Shinde, N. Dizeyi, A. Rosén, B. Sellergren, A. Gjörloff Wingren, Different expression levels of glycans on leukemic cells - a novel screening method 
with molecularly imprinted polymers (MIP) targeting sialic acid, Tumor Biology 37(10) (2016) 13763-13768.

[16] L. Sternbæk, M.W. Kimani, K. Gawlitza, B. Janicke, K. Alm, A. Wingren Gjörloff, Digital holographic microscopy: macrophage uptake of nanoprobes, Imaging and Microscopy (1) (2019) 21-23.

[17] M. Patel, M. Feith, B. Janicke, K. Alm, Z. El-Schich, Evaluation of the impact of imprinted polymer particles on morphology and motility of breast cancer cells by using digital holographic cytometry, Applied Sciences 10(3) (2020) 750.

[18] E. Johansson, R. Caraballo, N. Mistry, G. Zocher, W. Qian, C.D. Andersson, D.L. Hurdiss, N. Chandra, R. Thompson, L. Frängsmyr, Pentavalent sialic acid conjugates block coxsackievirus A24 variant and human adenovirus type 37-viruses that cause highly contagious eye infections, ACS chemical biology 15(10) (2020) 2683-2691.

[19] R. Caraballo, M. Saleeb, J. Bauer, A.M. Liaci, N. Chandra, R.J. Storm, L. Frängsmyr, W. Qian, T. Stehle, N. Arnberg, Triazole linker-based trivalent sialic acid inhibitors of adenovirus type 37 infection of human corneal epithelial cells, Organic \& biomolecular chemistry 13(35) (2015) 9194-9205.

[20] Y. Xie, Y. Sheng, Q. Li, S. Ju, J. Reyes, C.B. Lebrilla, Determination of the glycoprotein specificity of lectins on cell membranes through oxidative proteomics, Chemical Science 11(35) (2020) 9501-9512.

[21] Z. El-Schich, Y. Zhang, T. Göransson, N. Dizeyi, J.L. Persson, E. Johansson, R. Caraballo, M. Elofsson, S. Shinde, B. Sellergren, Sialic Acid as a Biomarker Studied in Breast Cancer Cell Lines In Vitro Using Fluorescent Molecularly Imprinted Polymers, Applied Sciences 11(7)

(2021) 3256. 



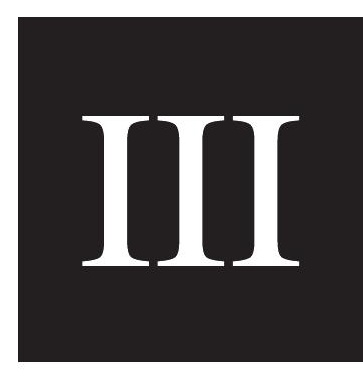





\title{
Determination of cytokine regulated glycan expression by using molecularly imprinted polymers targeting sialic acid
}

\author{
Yuecheng Zhang, Kushtrim Llapashtica, Sudhirkumar Shinde, Börje Sellergren, Zahra El-Schich, Anette \\ Gjörloff Wingren
}

Department of Biomedical Sciences, Faculty of Health and Society, Malmö University, Malmö 20506, Sweden.

Correspondence to: Dr. Anette Gjörloff Wingren, Department of Biomedical Sciences, Faculty of Health and Society, Malmö University, Malmö 20506, Sweden. E-mail: Anette.gjorloff-wingren@mau.se

\begin{abstract}
How to cite this article: Zhang Y, Llapashtica K, Shinde S, Sellergren B, El-Schich Z, Wingren AG. Determination of cytokine regulated glycan expression by using molecularly imprinted polymers targeting sialic acid. J Cancer Metastasis Treat 2019;5:56. http://dx.doi.org/10.20517/2394-4722.2018.112
\end{abstract}

Received: 31 Dec 2018 First Decision: 18 Mar 2019 Revised: 16 Apr 2019 Accepted: 28 May 2019 Published: 11 Jul 2019

Science Editor: Rafat Siddiqui Copy Editor: Cai-Hong Wang Production Editor: Jing Yu

\begin{abstract}
Cancer cells often have an increased amount of glycans, such as sialic acid (SA), on the cell surface, which normally play an important role in cell growth, proliferation and differentiation. In this study, SA expression is determined by fluorescent nanoprobes, molecularly imprinted polymers, SA-MIPs. The nanoprobes are synthesized with an imprinting approach to produce tailor-made fluorescent core-shell particles with high affinity for cell surface SA. Inflammation and cytokine production are well known tumor promoters, modulating the cellular microenvironment, including an aberrant cell surface glycan pattern. The recombinant cytokines IL-4, IL-6, IL-8 and a cocktail of cytokines collected from stimulated T leukemia Jurkat cells were used to induce in vitro inflammation in two cell lines, and thereafter analyzed with the use of SA-MIPs and flow cytometry. One of the cell lines showed a different binding pattern of SA-MIPs after treatment with recombinant cytokines and the cytokine cocktail. This study shows that SA-MIPs can be an important tool in the investigation of overexpressed glycans in the tumor microenvironment.
\end{abstract}

Keywords: Cancer, cytokine, glycans, molecularly imprinted polymers, sialic acid

\section{INTRODUCTION}

Abnormal cell growth can be initiated through inflammation ${ }^{[1]}$. Cancer cells are able to reshape the microenvironment by expression of tumor-promoting chemokines and cytokines ${ }^{[2,3]}$. Fast growing cancer 
cells outpace their blood supply and become nutrient and oxygen deprived. This results in necrotic cell death at the tumor's core and this releases pro- inflammatory cytokines, such as IL-1.

Cytokines act as cell regulators of many different biological processes including cell growth, differentiation, metabolism, immunity and inflammation. Cytokines can enhance cancer cell growth by modulating the cellular microenvironment or by affecting the cells directly. Pro- inflammatory cytokines can be oncogenic and thereby inducing elevated levels of pro- invasive factors such as metalloproteinase-2 (MMP-2) and epithelial growth factor.

Pro-inflammatory cytokines including TNF- $\alpha$, IL-1 $\beta$, IL- 6 and IL- 8 are regulated by the transcription factor NF-kB, which is involved in activating genes in neoplastic transformation ${ }^{[1,4]}$. Highly glycosylated intestinal mucins, such as MUC2 and MUC4, are regulated through NF-KB and by the gp130/STAT3 pathways, respectively ${ }^{[5,6]}$.

Sialic acid (SA), or neuraminic acid, is the outermost sugar molecule of glycans, thus forming the outer surface of cells by being attached to proteins or lipids bound to the plasma membrane. SA is very important for the function of living organisms since it is involved in cell processes like proliferation, differentiation, angiogenesis, invasiveness and metastasis ${ }^{[7,8]}$. The over-expression of SA creates a negative charge on the cell surface, which is important in cell-cell and cell-matrix communication. An increased level of SA on the cell membrane, which have been reported on malignant and metastatic cancer cells, makes cells repel each other leading to an increased motility ${ }^{[9]}$. In addition, it has been proven that aberrant expression of in particular the $\alpha 2,3-\mathrm{SA}$ variants are related to tumor adhesion and invasion ${ }^{[10,11]}$.

Today, there is a lack of tools for specific targeting to glycans with high affinity. Lectins and glycan-specific antibodies have been used by many research groups to detect altered glycosylation, but the current tools do not perform with high specificity or affinity ${ }^{[12]}$. We have developed fluorescent nanoprobes to make convenient targeting and imaging of cell surface SA possible ${ }^{[13]}$. Based on other glycan specific receptors, we have developed SA-imprinted molecularly polymers (SA-MIPs) by using silica core particles and implemented NBD-fluorophores, which have favorable spectroscopic properties ${ }^{[13,14]}$.

In this study, two different cancer cell lines, MCF-7 and RAW 264.7, were stimulated with recombinant IL-4, IL-6, IL-8 and a cocktail of cytokines obtained by stimulating Jurkat T leukemia cells with phytohemagglutinine (PHA). The resulting expression of SA on the membrane of the stimulated cancer cells was analyzed with flow cytometry using both lectins and the SA-MIPs. One of the cell lines showed an increased binding of the SA-MIPs after treatment with recombinant cytokines and with the cytokine cocktail from PHA-stimulated Jurkat cells.

\section{MATERIAL AND METHODS}

\section{Cell culture}

The cell lines MCF-7 (ATCC HTB-22), RAW 264.7 (ATCCTIB-71) and Jurkat (ATCCTIB-152) were obtained from the American Type Culture Collection (ATCC/LGC Standards, Teddington, UK). MCF-7 and Jurkat cells were cultured in RPMI-1640 medium (Invitrogen, San Diego, CA, USA) supplemented with $10 \%$ fetal bovine serum (FBS, Invitrogen) and $50 \mu \mathrm{g} / \mathrm{mL}$ gentamycin (Invitrogen) (complete medium). RAW 264.7 cells were cultured in RPMI-1640 medium supplemented with 10\% FBS and penicillin-streptomycin (Invitrogen). The cell lines were incubated in $37^{\circ} \mathrm{C}$ with $5 \% \mathrm{CO}_{2}$ in $100 \%$ humidity.

\section{Stimulation of Jurkat cells}

$5 \times 10^{6}$ Jurkat cells in $5 \mathrm{~mL}$ of were stimulated in complete medium with the addition of $10 \mathrm{ug} / \mathrm{mL}$ of PHA (Sigma Aldrich, St Louis, USA) for $72 \mathrm{~h}$. The cells were harvested and centrifuged at $300 \mathrm{xg}$ for $10 \mathrm{~min}$. The supernatant was kept at $4{ }^{\circ} \mathrm{C}$ until used for cell experiments. 


\section{Addition of recombinant cytokines}

$2 \times 10^{6}$ of each of MCF-7 and RAW 264.7 cells were seeded in T25 flasks. Next day, the medium was removed and the different recombinant cytokines IL-4, IL-6, IL-8 (Peprotech, Rocky Hill, NJ, USA), all added at a final concentration of $40 \mathrm{ng} / \mathrm{mL}$, or undiluted PHA- stimulated Jurkat supernatant was added to the cell culture flasks. One flask served as control with cells and medium alone. The cells were harvested after 3 days of incubation by trypsinization, two washes with phosphate buffered saline (PBS, Invitrogen) and thereafter stained with SA-MIPs according to below.

\section{Preparation of polymers}

The polymers (SA-MIPs) were prepared as described previously by Shinde et al ${ }^{[13]}$. Before the SA-MIPs were used for cell-based experiments, the dried SA-MIPs were resuspended in PBS and sonicated for 8 min with a VWR sonicator. The stock solution of $1 \mathrm{mg} / \mathrm{mL}$ was further sonicated and diluted in PBS prior to use.

\section{Flow cytometry analysis}

\section{SA-MIPS}

$1 \times 10^{6}$ cells/sample were stained with SA-MIPs or left unstained as a control. The cells were washed twice with $2 \mathrm{~mL}$ PBS and thereafter $100 \mu \mathrm{L}$ of SA-MIPs with indicated concentration was added to the cells. $100 \mu \mathrm{L}$ of PBS was used as a negative control. The cells were incubated with SA-MIP for $30 \mathrm{~min}$ at $4{ }^{\circ} \mathrm{C}$ in the dark, and were thereafter washed three times with $2 \mathrm{~mL}$ PBS and analyzed using flow cytometry (BD Biosciences, Accuri C6 Flow Cytometry, NJ).

\section{Lectins conjugated with biotin}

$1 \times 10^{6}$ cells/sample were stained with biotin-conjugated lectins (Vector Labs, Burlingame, CA, USA) or left unstained as a control. The cells were washed twice with $2 \mathrm{~mL}$ PBS. $100 \mu \mathrm{L}$ of biotin-conjugated lectins, MAL I (from Maackia amurensis) or SNA (from Sambucus nigra) at concentrations of $10 \mu \mathrm{g} / \mathrm{mL}$ was added to the cells and $100 \mu \mathrm{L}$ of PBS was used as a negative control. The cells were incubated with biotin- conjugated lectins for $30 \mathrm{~min}$ on $4{ }^{\circ} \mathrm{C}$ and were thereafter washed three times with $2 \mathrm{~mL}$ PBS. Thereafter $100 \mu \mathrm{L}$ of a 1:100 dilution of streptavidin-FITC (Agilent Technologies, Santa Clara, CA, USA) was added to the cells and incubated for $20 \mathrm{~min}$ at $4{ }^{\circ} \mathrm{C}$ in the dark. After the incubation, the cells were washed three times with $2 \mathrm{~mL}$ PBS and analyzed using flow cytometry (Accuri C6 Flow Cytometry).

ELISAs for IL-2, IL-6, IL-8 and TNF-a

96-well ELISA plates were coated overnight at room temperature with $100 \mu \mathrm{L} /$ well of diluted capture antibody against IL-2, IL-6, IL-8 or TNF- $\alpha$, respectively, according to the manufacturer's instructions (R\&D Systems, Minneapolis, MN, USA). The plates were washed three times with PBS-Tween (PBS-T), blocked by adding $300 \mu \mathrm{L} /$ well of blocking buffer (1\% BSA in PBS) and thereafter incubated at room temperature (RT) for $1 \mathrm{hr}$. After three washes with PBS-T, the plates were incubated with $100 \mu \mathrm{L} /$ well IL-2, IL-6, IL-8 or TNFstandards, respectively, diluted in reagent diluent, and $100 \mu \mathrm{L} /$ well of samples collected from the Jurkat cell supernatant. After an incubation of $2 \mathrm{~h}$ at RT, the plates were washed three times and thereafter100 $\mu \mathrm{L} /$ well of $50 \mathrm{ng} / \mathrm{mL}$ biotin-linked detection antibody against IL-2, IL-6, IL-8 or TNF- $\alpha$, respectively, were added and incubated at RT for $2 \mathrm{~h}$. Then washed the plates three times and incubated with streptavidin-HRP at room temperature for $20 \mathrm{~min}$. After three washes with PBS-T, the plates were incubated with $100 \mu \mathrm{L} /$ well with substrate solution (1:1 mixture of $\mathrm{H}_{2} \mathrm{O}_{2}$ and tetramethylbenzidine, TMB) at RT for $20 \mathrm{~min}$. After that, $100 \mu \mathrm{L} /$ well of stop solution was added and the plates were analyzed with a spectrophotometer at $450 \mathrm{~nm}$.

\section{Statistical methods}

Mean and standard deviation were used for statistical analysis of all calculations. 


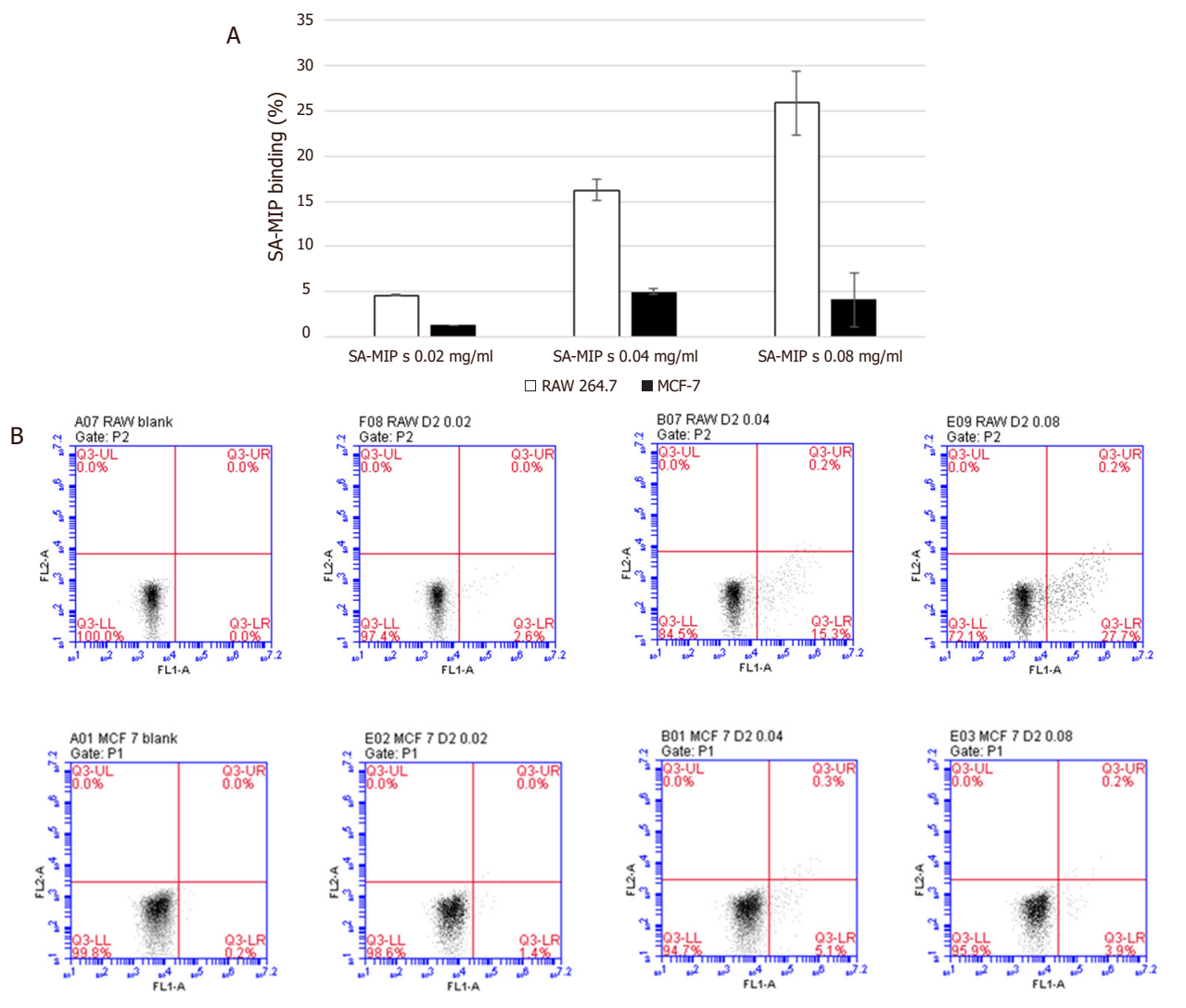

Figure 1. SA-MIP binding to RAW 264.7 cells and MCF-7 cells. A: Results of cells RAW 264.7 cells and MCF-7 cells stained with different concentrations of SA-MIP. B: Flow cytometry diagrams present the positive cells for SA-MIP concentrations $0.02,0.04$ and $0.08 \mathrm{mg} / \mathrm{mL}$, as dot-plot diagrams, respectively. The experiment shown in A represents the average of least three performed

\section{RESULTS}

\section{Evaluation of SA-MIP binding to MCF-7 and RAW 264.7 cells}

The breast cancer cell line MCF-7 and the macrophage cell line RAW 264.7 were tested for SA-MIP binding at different concentrations. Addition of increased concentration of SA-MIP resulted in higher SA-MIP binding [Figure $1 \mathrm{~A}$ ]. At the highest concentration of SA-MIPs used, $0,08 \mathrm{mg} / \mathrm{mL}$, the staining result was around $5 \%$ cell binding for MCF-7 cells and 65\% cell binding for RAW 264.7 cells. The dot-plot diagrams for RAW 264.7 cells (Upper figures) and MCF-7 cells (Lower figures) are shown in Figure 1B.

\section{SA-specific lectins show an increased binding to MCF-7 and RAW 264.7 cells after treatment with a cytokine cocktail}

First, the expression of SA on the cell lines were confirmed by using the lectins MAL I and SNA [Figure 2]. Then, the cells were treated with the cytokine cocktail from PHA-stimulated Jurkat cells, and a significant increased binding of the lectins could be detected in both cell lines [Figure 2].

\section{Cytokine treated MCF-7 and RAW 264.7 cells show a variation in SA-MIP binding}

Both cell lines were treated with the recombinant cytokines IL-4, IL-6 or IL-8. Alternatively, the cytokine cocktail from PHA-stimulated Jurkat cells was used. For the RAW 264.7 cells, treatment with IL-4 showed 




Figure 2. Lectin binding to RAW 264.7 cells and MCF-7 cells. Results of cells RAW 264.7 cells and MCF-7 cells stained with the MAL I and SNA lectins. Flow cytometry results present the mean fluorescence intensity for the lectins and a small increase in binding of the lectins after treatment with the cytokine cocktail. The experiment shown represents the average of least three performed

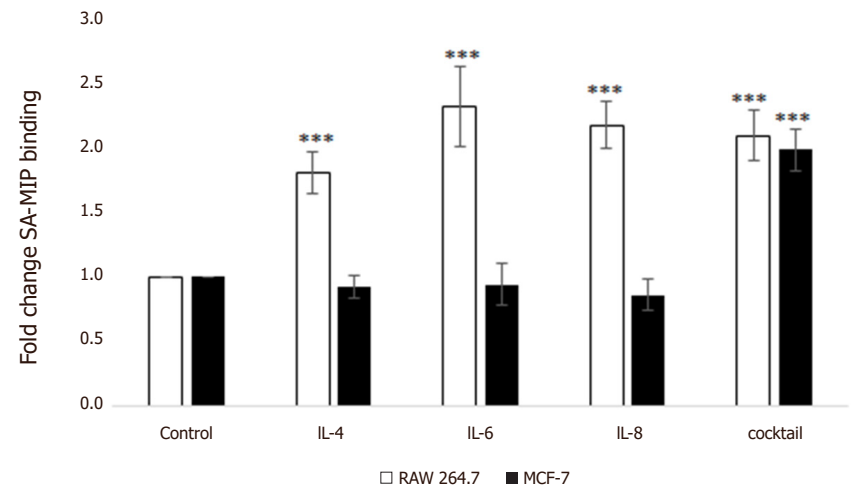

Figure 3. Flow cytometry of cytokine-treated RAW264.7 cells showing increase in SA-MIP binding after IL-4, IL-6, IL-8 or cocktail treatment. Results of cells RAW 264.7 cells and MCF-7 cells stained with SA-MIP. Flow cytometry results were re-calculated to fold change of response compared to control. The experiment shown represents the average of least three performed

an increase in SA-MIP binding in both cell lines, whereas IL-6 and IL-8 showed an even larger decrease [Figure 3]. The cytokine cocktail with unknown content influenced the SA-MIP binding in a similar manner as IL-6 and IL-8. All additions of cytokines to RAW 264.7 cells were found to be significantly different from the control, as determined by statistical calculations.

For the MCF-7 cell line, addition of the recombinant cytokines IL-4, IL-6 or IL-8 did not influence any increase of SA-MIP binding to the cells [Figure 3]. No statistical significant difference could be determined for cytokine treatment of MCF-7 cells. However, addition of the cytokine cocktail induced a 2-fold significant increase of SA-MIP binding in MCF-7 cells. To elucidate the cytokine content in the cocktail, ELISA was performed. 
Table 1. Cytokine content in PHA-stimulated Jurkat cells was analyzed with sandwich ELISAs detecting IL-2, II-6, IL-8 and TNF-, respectively

\begin{tabular}{lc}
\hline Cytokines analyzed with ELISA in PHA-stimulated Jurkat cell sample & Cytokines detected (pg/mL) \\
\hline IL-2 negative control & 0 \\
IL-2 stimulated sample & 17 \\
IL-4 negative control & n.d. \\
IL-4 stimulated sample & n.d. \\
IL-6 negative control & 0 \\
IL-6 stimulated sample & 0 \\
IL-8 negative control & 0 \\
IL-8 stimulated sample & 427 \\
TNF-negative control & 0 \\
TNF-stimulated sample & 12 \\
\hline
\end{tabular}

\section{PHA-stimulated Jurkat cells produce high amounts of IL-8}

The supernatants from stimulated and unstimulated Jurkat cells were investigated with sandwich ELISA specific for IL-2, IL-6, IL-8 and TNF- respectively [Table 1]. The levels of IL-2 and TNF- were low, but showed an increase compared to control. In contrast, more than $400 \mathrm{pg} / \mathrm{mL}$ of IL-8 was detected in the PHA-stimulated Jurkat cell supernatant. No IL- 8 could be detected in the unstimulated control. IL- 6 could not detected in either stimulated or unstimulated samples.

\section{DISCUSSION}

In the tumor microenvironment, the cells of the immune system communicate with each other by releasing chemokines and cytokines to either favor antitumor immunity or enhance tumor progression. Thereby the cells control the immune and inflammatory milieu in a sophisticated fashion.

In this study we demonstrate that the SA-expression of RAW 264.7 and MCF-7 cells treated with recombinant cytokines in vitro could be analyzed with the use of SA-MIPs and flow cytometry. Interestingly, the cytokine-treated cells showed a modulated SA-MIPs binding pattern compared to the unstimulated controls. Stimulating macrophage RAW264.7 cells with IL-4, IL-6 or IL-8 cause an up-regulation of SA-MIP binding, while for the MCF-7 cells no increase could be determined. The effect of inflammatory cytokines on pancreatic cancer cells has been reviewed by Roshani et $\mathrm{l}^{\left[{ }^{1]}\right.}$. In other studies, IL-4 did not have any effect, but IL- 6 and IL-8 were associated with poor prognosis and increased aggressiveness, respectively. IL-4 is an anti-inflammatory cytokine expected to down-regulate SA, while IL-6 and IL-8 both up-regulate the SA expression. Indeed, IL- 6 and IL- $8^{[15-17]}$, as well as anti-inflammatory cytokines IL-10 and tumor growth factor-beta (TGF- $\beta)^{[15,18,19]}$ have been commonly shown to be elevated in pancreatic patients. Also, TNF- and IL- were upregulated compared to controls, but all studies in pancreatic cancer patients did not come to the same conclusions ${ }^{[1]}$. Other studies have proven that the levels of IL-4, IL-6 and IL-8 in pancreatic cancer patients is higher than normal ${ }^{[15]}$. An important remark is that the pattern of cytokine expression varies between studies and even contradicting results have been obtained. Bassaganas et al. ${ }^{[20]}$ studied pancreatic ductal adenocarcinoma cell lines treated with different cytokines. They found that treatment with either IL-1 or IL-6 resulted in an increased carbohydrate antigen and SA level. Also, the levels of mRNA of precursor of carbohydrate antigens was enhanced. Moreover, Dima et al. ${ }^{[19]}$ found an association between higher levels of circulating TNF- $\alpha$ with poorer prognosis. These findings indicate that inflammatory cytokines can be pursued as potential prognostic biomarkers as well as therapeutic targets.

Escaping immune recognition is now a recognized hallmark of cancer $^{[21]}$. Chemokines and cytokines can play a critical role in the immune evasion. Tumor cells can escape host immunity by producing immunosuppressive cytokines as well as by recruiting regulatory immune cells with immunosuppressive functions. 
The cellular expression pattern of glycosyltransferases and Lewis antigens detected in the normal mucosa can change during neoplastic transformation. The stomach mucosa was investigated for Lewis antigens in the presence of pro-inflammatory cytokines ${ }^{[4]}$. The level of one type of Lewis antigen decreased after treatment with IL-1 or IL-6, whereas the levels of other carbohydrate antigens were unaffected ${ }^{[4]}$.

Lectins are plant-derived macromolecules specific for carbohydrate moieties. The MAL lectin specifically bind the sialyl $\alpha 2,3 \mathrm{Gal} \beta 1,4 \mathrm{GlcNAc} / \mathrm{Glc}$ trisaccharide sequence ${ }^{[22]}$. Expression of $\alpha 2,3-\mathrm{SA}$ residues of $\mathrm{N}$-cadherin was shown to be altered in metastatic melanoma cell lines ${ }^{[23]}$. The expression of $\alpha 2,3-\mathrm{SA}$ residues in breast cancer using MAL-staining were analyzed by Cui et al. ${ }^{[2]}$ The results suggested that high levels of $\alpha 2,3$-SA residues was closely associated with lymph node metastasis and invasive depth in breast cancer patients. The highly metastatic breast cancer cell line MDA-MB-231 had higher expression of $\alpha 2,3$-sialic acid residues compared to T-47D and MCF-7 depending on the mRNA levels of $\alpha 2,3-\mathrm{ST}$ genes. Indeed, the tumor microenvironment can direct the level of inflammation. Also, the metastatic potential and malignancy of cancer cells is closely associated with aberrant sialylation pattern ${ }^{[24]}$.

The enzyme that adds $\alpha 2$-6linked sialic acids, $\beta$-galactoside $\alpha 2-6$ sialyltransferase (ST6Gal-I), is known to be upregulated in many tumor types including colon adenocarcinomas ${ }^{[25]}$, and high expression levels have been associated with poor prognosis and metastasis. ST6Gal-I sialylation of membrane glycoproteins contributes to metastasis by enhancing cell motility and invasion through the extra cellular matrix (ECM). Increased negative charged properties of sialic acids was correlated with reduced adhesiveness of tumor cells and may be suitable for conformational change of integrin and enhances its function in cell-ECM interactions ${ }^{[26]}$.

Interestingly, in our study we show a high expression of $\alpha 2,3-\mathrm{SA}$ on both cell lines, whereas the $\alpha 2,6-\mathrm{SA}$, as analyzed with the lectin SNA, displayed a lower expression on the MCF-7 cells. It has been shown that high levels of sialylation of cell surface glycoconjugates can significantly increase metastasis of colon carcinoma cells and human melanoma cells.

In addition to directly modulating cell motility, $\alpha 2,3-\mathrm{SA}$ residues are involved in the synthesis of sialyl Lewis $\mathrm{X}$ determinants, which are the major ligands for endothelial E-selectin ${ }^{[27]}$. The sialyl Lewis $\mathrm{X}$ structure on malignant cells is suggested to facilitate tumor cell dissemination by mediating the tumor-endothelial cell interaction ${ }^{[28,29]}$. Overall, many studies support the hypothesis that an increase of sialylation of cancer cells play an important role in tumor metastasis.

In the present study, the MCF-7 cell line showed a small increase of the SA-MIP binding after treatment with the cytokine cocktail derived from PHA-stimulated Jurkat cells. On the other hand, the SA-MIP binding when treating the RAW264.7 cell line with the same cocktail was not different compared to the effect of recombinant IL-6 or IL-8. Interestingly, an increase in binding of the lectins MAL and SNA was also detected after cytokine cocktail treatment. By analyzing with ELISA, we show that the cocktail contains increased amounts of IL-8, as well as low levels of IL-2 and TNF- $\alpha$. IL- 6 could not be detected in the PHA-stimulated samples. IL-8 is a chemokine, functioning by attracting cells to a site of infection, and it is therefore tempting to speculate that the increased SA-MIP binding seen by the RAW264.7 cells, could be due to a regulated SA-expression in response to IL-8. The natural ligands for SA are selectins and siglecs ${ }^{[30]}$. Indeed, the rolling of cancer cells ectopically expressing the selectin ligands on endothelial cells is potentially a crucial step favoring the metastatic process in $v i v o^{[3]}$. The combined analysis of SA and the targeting of SA to the ligands selectins and siglecs will be attractive for further investigations.

In conclusion, cancer cell migration and invasion is controlled by protein glycosylation and the ECM. SA is one of several important players in this crucial process. Inflammation and cytokine production will modulate the cellular microenvironment. We have studied cell lines in vitro that showed that one of the cell 
lines showed a significantly increased binding of the SA-MIPs after treatment with recombinant cytokines and with the cytokine cocktail from PHA-stimulated Jurkat cells. Here we demonstrate that SA-MIPs can be an important tool in the investigation of overexpressed glycans in the tumor microenvironment.

\section{DECLARATIONS}

\section{Authors' contributions}

Made substantial contributions to conception and design of the study and performed data analysis and interpretation: Zhang Y, Llapashtica K, Wingren AG

Performed data acquisition, as well as provided administrative, technical, and material support: El-Schich Z Provided administrative, technical, and material support: Shinde S, Sellergren B

\section{Availability of data and materials}

Not applicable.

\section{Financial support and sponsorship}

This work was supported by the European Union's Horizon 2020 research and innovation program under the Marie Sklodowska-Curie grant agreement (No 721297); the Knowledge foundation, Biofilms Research Center for Biointerfaces and Malmö University for financial support.

\section{Conflicts of interest}

All authors declared that there are no conflicts of interest.

\section{Ethical approval and consent to participate}

Not applicable.

\section{Consent for publication}

Not applicable.

\section{Copyright}

The Author(s) 2019.

\section{REFERENCE}

1. Roshani R, McCarthy F, Hagemann T. Inflammatory cytokines in human pancreatic cancer. Cancer Lett 2014;345:157-63.

2. Soucek L, Lawlor E, Soto D, Shchors K, Swigart LB, et al. Mast cells are required for angiogenesis and macroscopic expansion of Mycinduced pancreatic islet tumors. Nat Med 2007;13:1211-18.

3. Sparmann A, Bar-Sagi D. Ras-induced interleukin-8 expression plays a critical role in tumor growth and angiogenesis. Cancer Cell 2004;5:447-58.

4. Padro M, Mejias-Luque R, Cobler L, Garrido M, Perez-Garay M, et al. Regulation of glycosltransferases and Lewis antigens expression by IL-1B and IL-6 in human gastric cells. Glycoconj J 2011;28:99-110.

5. Mejias-Luque R, Linde, SK, Garrido M, Tye H, Najdovska M, et al. Inflammation modulates the expression of the intestinal mucins MUC2 and MUC4 in gastric tumors. Oncogene 2010;12:1753-62.

6. Mejias-Luque R, Peiro S, Vincent A, Van Seuningen I, deBolos C. IL-6 induces MUC4 expression through gp130/STAT3pathway in gastric cancer cell lines. Biochim. Biophys. Acta 2008;1783:1728-36.

7. Fuster MM, Esko JD. The sweet and sour of cancer: Glycans as novel therapeutic targets. Nat Rev Cancer 2005;5:526-42.

8. Varki, A. Sialic acids in human health and disease. (Invited Essay) Trends Mol. Med. 2008;14:351-60.

9. Dall'Olio, FC. Sialyltransferases in cancer. Glycoconjugate J 2001;18:841-50.

10. Czyzewska J, Guzińska-Ustymowicz K, Kemona A, Bandurski R. The expression of matrix metalloproteinase 9 and cathepsin B in gastric carcinoma is associated with lymph node metastasis, but not with postoperative survival. Folia Histochem Cytobiol 2008;46:5764.

11. Lin S, Kemmner W, Grigull Sand Schlag PM. Cell surface alpha 2,6 sialylation affects adhesion of breast carcinoma cells. Exp Cell Res 2002;276:101-10. 
12. Foster A, Brid R, Kelly S, Nishimura K, Poyner D, et al. FITC-Lectin avidity of Cryptocoous neoformans cell wall and capsular components. Mycologia 2004;96:1-8.

13. Shinde S, El-Schich Z, Malakpour A, Wan W, Dizeyi N, et al. Sialic acid-imprinted Fluorescent core-shell particles for selective labeling of cell surface glycans. JACS 2015;137:13908-12.

14. El-Schich Z, Abdullah M, Shinde S, Dizeyi N, Rosén A, et al. Different expression of glycans on leukemic cells - a screening with molecularly imprinted polymers targeting sialic acid. Tumor Biol 2016;37:13763-8.

15. Tucker SL, Ebrahimi B, Li D, Abbruzzes JL, Kurzrock R. Cytokines in pancreatic carcinoma: correlation with phenotypic characteristics and prognosis. Cancer 2004;101:2727-36.

16. Zhang Y, Li M, Feurino LW, Wang H, Fisher WE, et al. Interleukin-8 increases vascular endothelial growth factor and neuropilin expression and stimulates ERK activation in human pancreatic cancer. Cancer Sci 2008;99:733-7.

17. Miron M, Miron MM, Mile VG, Cristea V. Proinflammatory cytokines: an insight into pancreatic oncogenesis, Roum. Arch. Microbiol Immunol 2010;69:183-9.

18. Smirne C, Bellone G, Mauri FA, Tonel E, Carbone A, et al. Cytokine expression profile in human pancreatic carcinoma cells and in surgical specimens: implications for survival, Cancer Immunol. Immunother 2006;55:684-98.

19. Dima SO, Tanase C, Albulescu R, Herlea V, Chivu-Economescu M, et al. An exploratory study of inflammatory cytokines as prognostic biomarkers in patients with ductal pancreatic adenocarcinoma. Pancreas 2012;41:1001-7.

20. Bassaganas S, Allende H, Cobler L, Ortiz MR, Llop E, et al. Inflammatory cytokines regulate the expression of glycosyltransferases involved in the biosynthesis of tumor- associated sialylated glycans in pancreatic cancer cell lines. Cytokine 2015;75:197- 206.

21. Hanahan D, Weinberg RA. Hallmarks of cancer: the next generation. Cell 2011;144:646-74.

22. Imberty A, Gautier C, Lescar J, Pérez S, Wyns Land Loris R. An unusual carbohydrate binding site revealed by the residues of two Maackia amurensis lectins complexed with sialic acid-containing oligosaccharides. J Biol Chem 2000;275:17541-8.

23. Ciolczyk-Wierzbicka D, Gil D, Hoja-Lukowicz D, Litynska A, Laidler P. Carbohydrate moieties of N-cadherin from human melanoma cell lines. Acta Biochim Pol 2002;49:991-9.

24. Cui H, Lin Y, Yue L, Zhao X, Liu, J. Differential expression of the $\alpha 2,3$-sialic acid residues in breast cancer is associated with metastatic potential. Oncol Rep 2011;25:1365-71.

25. Shaikh FM, Seales EC, Clem WC, Hennessy KM, Zhou Y, et al. Tumor cell migration and invasion are regulated by expression of variant integrin glycoforms. Exp Cell Res 2008;314:2941-50.

26. Seales EC, Jurado GA, Brunson BA, Wakefield JK, Frost AR, et al. Hypersialylation of betal integrins, observed in colon adenocarcinoma, may contribute to cancer progression by up-regulating cell motility. Cancer Res 2005;65:4645-6.

27. Kannagi R, Izawa M, Koike T, Miyazaki K, Kimura N. Carbohydrate-mediated cell adhesion in cancer metastasis and angiogenesis Cancer Sci 2004;95:377-84.

28. Chen S, Fukuda M. Cell type-specific roles of carbohydrates in tumor metastasis. Methods Enzymol 2006;416:371-80.

29. Miyazaki K, Ohmori K, Izawa M, Koike T, Kumamoto K,et al. Loss of disialyl Lewis(a), the ligand for lymphocyte inhibitory receptor sialic acid-binding immunoglobulin-like lectin-7 (Siglec-7) associated with increased sialyl Lewis(a) expression on human colon cancers. Cancer Res 2004;64:4498-505.

30. Rodrigues E, Macauley MS. Hypersialylation in cancer: modulation of inflammation and therapeutic opportunities. Cancers (Basel) 2018;10:E207.

31. Trinchera M, Aronica A, Dall'Olio FC. Selectin ligands sialyl-Lewis a and sialyl- Lewis x in gastrointestinal cancers. Biology 2017;6:E16. 

IV 



\section{SARS-CoV-2 spike protein interaction with cell}

\section{types from tissue susceptible to viral infection}

Yuecheng Zhang ${ }^{1,2}$, Thomas Sjöberg ${ }^{1,2}$, Sarah Beyer ${ }^{1}$, Reuben Victor Laguitan ${ }^{1}$, Emil

Johansson $^{4,5}$, Niklas Arnberg ${ }^{4,5}$, Mikael Elofsson ${ }^{4,5}$, Jenny Persson ${ }^{1,2,3}$, Börje Sellergren ${ }^{1,2}$, Lars

Ohlsson $^{1,2}$, Zahra El-Schich ${ }^{1,2}$, Maria M. Stollenwerk ${ }^{1,2}$, Anette Gjörloff Wingren ${ }^{1,2^{*}}$

1) Department of Biomedical Sciences, Faculty of Health and Society, Malmö University, Malmö, Sweden

2) Biofilms-Research Center for Biointerfaces, Malmö University, Malmö, Sweden

3) Department of Molecular Biology, Umeå University, Umeå, Sweden

4) Centre for Microbial Research, Umeå University, Umeå, Sweden

5) Department of Chemistry, Umeå University, Umeå, Sweden

Corresponding author: Anette Gjörloff Wingren (Anette.gjorloff-wingren@mau.se) 


\begin{abstract}
Identifying the receptor interaction of the receptor binding domain (RBD) originating from severe acute respiratory syndrome coronavirus 2 (SARS-CoV-2) with ACE2 and co-receptors has major implications for understanding the pathogenesis and future treatment strategies for COVID-19. This study aimed to evaluate a panel of human cell lines from tissue susceptible to viral infection, according to the initial outcome of COVID-19 pandemic outbreak. In addition, the African green monkey kidney cell line VeroE6 was included in this study. The cell lines derived from lung, skin, liver and colon were investigated for their expression of ACE2, binding of the receptor binding motif (RBM) and RBD constructs, and expression of TMPRSS2. The results from the flow cytometry study demonstrated that the polyclonal ACE2 antibody used, showed affinity for most of the cell lines included in the study. The specificity of the ACE2 antibody was evaluated by using a control isotype specific goat antibody and by pre-treating the ACE2 antibody with recombinant ACE2 before cell staining. Out of the ten cell lines analysed, the skin carcinoma cell line A-431 showed the lowest binding of the ACE2 antibody. The evaluation of the RBD binding results demonstrated that out of the ten cell lines analysed, the colorectal adenocarcinoma COLO 205 and the lung adenocarcinoma Calu-3 displayed the highest binding to RBD, whereas the skin carcinoma cell line A-431 showed the lowest binding. TMPRSS2 protein expression was evaluated by another antibody and the results revealed that the protease was expressed to a higher extent on COLO 205 and Calu-3 cells, and to a much lower extent on A-431 cells. The gene expression of ACE2 and TMPRSS2 was found in all cells analysed. To evaluate the importance of glycosylated structures on the RBD binding to ACE2, such as sialic acid (SA), we utilized the enzyme neuraminidase that cleave off these structures from the cell surface. The results revealed that SA did not influence the binding of RBD. In conclusion, the data highlighted in this study demonstrate the importance of evaluating ACE2 and co-receptor expression in different SARS-CoV-2 susceptible cell types, as well as the conformation and availability of these epitopes on the cell surface.
\end{abstract}

Keywords: Angiotensin-converting enzyme 2, receptor binding domain, SARS-CoV-2, TMPRSS2 


\section{Introduction}

According to the World Health Organization (WHO), around 230 million Coronavirus Disease 2019 (COVID-19) cases have been confirmed globally, leading to more than 4 million deaths [1]. The severe acute respiratory syndrome coronavirus 2 (SARS-CoV-2), leading to COVID19 is a positive-strand RNA virus [2,3]. As a new coronavirus member, it's genome shares about $96 \%$ and $80 \%$ identity with bat coronavirus BatCoV RaTG13 and the SARS-CoV-1, respectively $[2,4]$. Compared with SARS-CoV-1, SARS-COV-2 is more readily transmitted from human to human. This virus can cause various symptoms, including cough, fever, breathing difficulty, acute respiratory distress, and death $[5,6]$. Elderly patients and people with chronic underlying diseases, SARS-CoV-2 are exposed to greater risk to serious symptoms causing massive hospitalization rates and high mortality. Up to now, SARS-CoV-2 remains a significant challenge to human beings, and it is urgent to understand the mechanism of binding and infection to find strategies for treating individuals that are affected by the virus.

The viral spike (S) glycoprotein facilitates entry and targets angiotensin-converting enzyme 2 (ACE2) on the host cells $[3,7,8]$. It is an enzyme involved in the renin-angiotensin system (RAS) which could regulate blood pressure and electrolyte homeostasis. Already in 2003, Li et al. were the first research group to identify ACE2 as a functional receptor for SARS-CoV [9]. Zhou et al. confirmed that ACE2 is the cellular receptor for SARS-CoV-2 by viral transfection experiments using HeLa cells expressing or did not expressing (untransfected) ACE2. The results showed that SARS-CoV-2 could only enter HeLa cells that expressed ACE2 [2].

The full-length of the S protein is first produced as a precursor of 1273 aa that trimerizes (Figure 1). It is comprised by two fragments: the $\mathrm{S} 1$ subunit, including the receptor-binding domain (RBD, 319-541 residues) which recognizes and binds to the host receptor; and the S2 subunit (686-1273 residues) which mediates the virus-to-cell membrane fusion process $[7,10,11]$. 


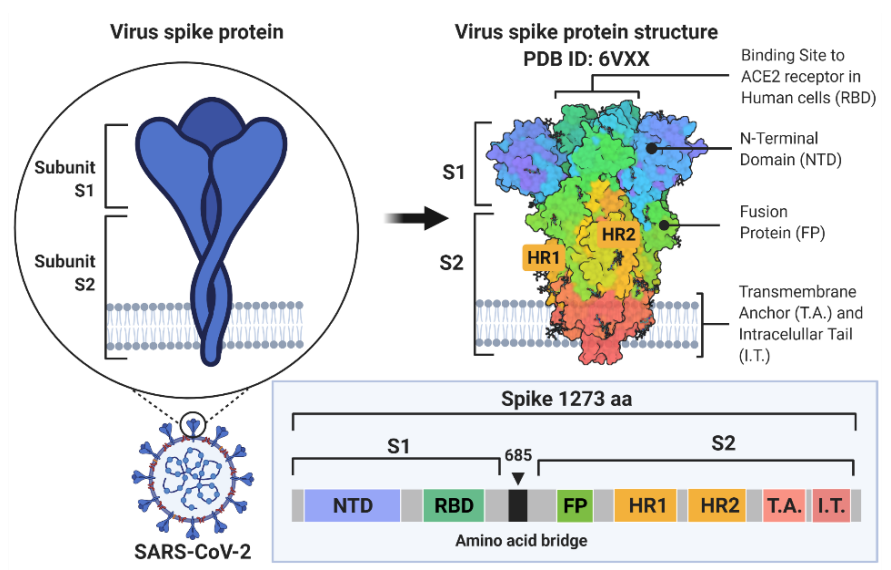

Figure 1. Overview of the spike protein. Spike protein is divided in two subunits; S1, including the receptor binding domain, the binding site to ACE2 receptor and S2 that include the transmembrane anchor and intracellular tail. Created using BioRender.com.

After the S glycoprotein recognizes and specifically conjugates on the host cell receptor ACE2 [3], the transmembrane protease serine 2 (TMPRSS2) on the host cell membrane activate the $\mathrm{S}$ glycoprotein and promote the membrane fusion process $[12,13]$. Hoffman et al showed that the S glycoprotein facilitates entry into a panel of mammalian cell lines, among others, A549, Calu3, Caco-2 and VeroE6 [13], and Wang et al. recently evaluated 25 cell lines commonly used in virus diagnostics and isolation for their susceptibility to SARS-CoV-2 [14]. Recently, other factors have been implicated that may be involved in SARS-CoV-2 entry including neuropilin1 [15], CD147 [16], CD209/CD209L [17].

Indeed, other molecules on the cell surface may also affect the infection process. Heparan sulfate was recently proven to be a co-receptor for RBD, and it was shown to effectively promote the spike-ACE2 interaction [18]. The monosaccharide sialic acid (SA) is another potential molecule which has been reported to be the receptor for many related coronaviruses, including $\mathrm{HCoV-OC43}$ and MERS, but it's possible role in SARS-CoV-2 interactions is still unclear $[19,20]$.

In this study, the ACE2 and TMPRSS2 expression were evaluated in cell lines possibly susceptible to viral infection. Subsequently, binding of RBM and RBD was performed. After comparing the binding pattern of RBD with ACE2 and TMPRSS2 protein expression, we found 
that the RBD binding pattern correlated well with both the ACE2 and TMPRSS2 expression levels. Furthermore, SA was evaluated for its potential role in the RBD-ACE2 interaction. Our study provides information about cell lines that can be useful in studies about binding of SARSCoV-2 to ACE2 and co-receptors.

\section{Material and methods}

\section{Cell culture}

The cell lines A-431 (skin epithelial), Caco-2 (colon epithelial), Calu-3 (lung adenocarcinoma epithelial), COLO 205 (colon epithelial), HaCaT (skin keratinocytes), SW48 (colon epithelial), A549 (lung epithelial), MCF7 (breast epithelial), Hep G2 (liver epithelial-like) and Vero E6 (monkey kidney epithelial) were obtained from American Type Culture Collection (ATCC) (Manassas, VA, USA). A-431 were cultured in Eagle's Minimum Essential Medium (EMEM, Sigma-Aldrich, St Louis, USA) supplemented with $10 \%$ fetal bovine serum (FBS, Thermo Fisher Scientific), 1\% L-Glutamine and 1\% non-essential amino acids, NEAA. Caco-2 cells were cultured in MEM medium supplemented with 20\% FBS, 1\% penicillin-streptomycin (PEST), 1\% NEAA, and 1\% L-Glutamine. Calu-3 and Hep G2 cells were cultured in MEM medium supplemented with 10 \% FBS. COLO 205 cells were cultured in RPMI-1640 medium supplemented with $10 \%$ FBS. HaCaT were cultured in DMEM medium supplemented with $10 \%$ FBS. SW48 cells were cultured in Leibovitz's L-15 Medium supplemented with 10\% FBS. A549 cells were cultured in RPMI-1640 medium supplemented with $10 \%$ FBS and 1\% PEST. MCF7 cells were cultured in RPMI-1640 medium supplemented with $10 \% \mathrm{FBS}$ and $50 \mu \mathrm{g} / \mathrm{mL}$ gentamycin. Vero E6 were cultured in DMEM supplemented with $10 \%$ FBS and 2 mM LGlutamine. The cell medium and reagents without labelling were purchased from Thermo Fisher Scientific and all the cell lines were cultured at $37{ }^{\circ} \mathrm{C}$ with $5 \% \mathrm{CO}_{2}$ in $100 \%$ humidity.

\section{Antibodies and reagents}

The polyclonal goat anti-ACE2 antibody (af933), normal goat IgG control, goat isotype control (AB-108-C), recombinant SARS-CoV-2 spike RBD Fc chimera, RBD-Fc (10499-CV) and recombinant ACE2 (rACE2; 933-ZN) were purchased from R\&D Systems Inc. (Minneapolis, MN, USA). The rabbit anti-TMPRSS2 antibody (Invitrogen PA514264) was obtained from Thermo Fisher Scientific (Waltham, MA USA). The secondary antibodies used were donkey anti-goat $\operatorname{IgG}(\mathrm{H}+\mathrm{L})$ conjugated with fluorescein (R\&D Systems, F0109), goat anti-Human IgG 
Fc conjugated with FITC (Thermo, H10001C) and swine anti-Rabbit Immunoglobulins conjugated with FITC (Dako, F0054).

\section{Flow cytometry staining protocols}

The cells were washed twice with phosphate buffered saline (PBS) and fixed with 4\% formaldehyde at room temperature (RT) for 10 mins. After two washes with PBS $+1 \%$ BSA (PBS-BSA), $5 \times 10^{5}$ cells were stained with anti-ACE2 antibody $(5 \mu \mathrm{g} / \mathrm{mL})$, goat isotype control (5 $\mu \mathrm{g} / \mathrm{mL})$, anti-TMPRSS2 antibody $(26 \mu \mathrm{g} / \mathrm{mL})$ or RBD-Fc $(10 \mu \mathrm{g} / \mathrm{mL})$. The cells were incubated in the dark at RT for 30 mins with a total volume of $100 \mu \mathrm{L}$, respectively. Unstained samples were used as controls for each cell line. After incubation, the samples were washed twice with PBS-BSA followed by staining with the corresponding secondary antibody in the dark at RT for 30 mins. Samples with secondary antibody alone were used as controls for each cell line. After incubation, the cells were washed twice with PBS-BSA and resuspended in 300 $\mu \mathrm{L}$ PBS for flow cytometer analysis.

\section{Pre-adsorption of anti-ACE2 and goat isotype control antibody using rACE2}

The cells were washed twice with PBS and fixed with 4\% formaldehyde at RT for 10 mins. After two washes with PBS (1\%BSA), $5 \times 10^{5}$ cells were pre-incubated with or without $2.5 \mu \mathrm{g}$ rACE2 for $1 \mathrm{~h}$ at RT. Thereafter, the cells were stained with anti-ACE2 antibody $(5 \mu \mathrm{g} / \mathrm{mL})$ or goat isotype control $(5 \mu \mathrm{g} / \mathrm{mL})$ and incubated in the dark at RT for 30 mins with a total volume of $100 \mu \mathrm{L}$, respectively. After incubation, the samples were washed twice with PBS (1\%BSA) followed by staining with the corresponding secondary antibody in the dark at RT for 30 mins. Samples with secondary antibody alone were used as controls for each cell line. After incubation, the cells were washed twice with PBS (1\%BSA) and resuspended in $300 \mu \mathrm{L}$ PBS for further analysis by flow cytometry.

\section{ACE2 and TMPRSS2 mRNA expression analysis}

The ACE2 and TMPRSS2 mRNA expression were analyzed by RT-PCR. First, the total RNA was extracted from $0.5 \times 10^{6}$ cells through RNeasy Mini Kit (Qiagen). Then the total RNA was reverse transcribed to cDNA using SensiFAST cDNA Synthesis Kit (Bioline). After that, the genes were amplified by PCR and the PCR product was analyzed by agarose gel electrophoresis. 
$\beta$-actin (human $A C T B$ ) was used as a reference gene. The sequence of specific primers are shown in Table $1[21]$.

Table 1. The sequence of the primers.

\begin{tabular}{|l|l|l|l|}
\hline Genes & Primers & Sequence $\mathbf{5}^{\prime} \mathbf{>} \mathbf{3}^{\prime}$ ) & Reference \\
\hline \multirow{2}{*}{$A C E 2$} & forward primer & GGGATCAGAGATCGGAAGAAGAAA & \multirow{2}{*}{ NM_021804 } \\
\cline { 2 - 4 } & reverse primer & AGGAGGTCTGAACATCATCAGTG & \\
\hline \multirow{2}{*}{$T M P R S S 2$} & forward primer & AATCGGTGTGTTCGCCTCTAC & \multirow{2}{*}{ NM_005656 } \\
\cline { 2 - 4 } & reverse primer & CGTAGTTCTCGTTCCAGTCGT & \\
\hline \multirow{2}{*}{$A C T B$} & forward primer & CCCTGGACTTCGAGCAAGAG & \multirow{2}{*}{ NM_001101 } \\
\cline { 2 - 4 } & reverse primer & ACTCCATGCCCAGGAAGGAA & \\
\hline
\end{tabular}

\section{Neuraminidase treatment}

The A549 lung epithelial cells were washed twice with PBS and fixed with 4\% formaldehyde at RT for 10 mins. Washed again twice with PBS ( $1 \%$ BSA), $5 \times 10^{5}$ cells were treated with 0.2 $\mathrm{U} / \mathrm{mL}$ neuraminidase (Sigma-Aldrich) at $37^{\circ} \mathrm{C}$ for $90 \mathrm{mins}$ and untreated cells were used as control. Then the cells were washed twice with PBS. The biotinylated lectins Maackia Amurensis Lectin I (MAL I), Sambucus Nigra Lectin (SNA) at $5 \mu \mathrm{g} / \mathrm{mL}$, respectively, or RBDFc $(10 \mu \mathrm{g} / \mathrm{mL})$ were added and incubated with the cells in the dark at RT for 30 mins with a total volume of $100 \mu \mathrm{L}$. Unstained samples were used as controls. After incubation, the samples were washed twice with PBS (1\% BSA) followed by staining with the corresponding secondary antibody or streptavidin-FITC (Sigma-Aldrich) in the dark at RT for 30 mins. Samples with secondary antibody or streptavidin-FITC alone were used as controls for each cell line.

\section{Inhibition assay with SA-derivatives}

In the inhibition assay, RBD-Fc $(10 \mu \mathrm{g} / \mathrm{mL})$ were pre-treated with different concentrations (20 and $200 \mu \mathrm{M}$ ) of SA-derivatives ME0976 or ME0752 at RT for 5 mins before incubated with the cells in the dark at RT for 30 mins with a total volume of $100 \mu \mathrm{L}$. Unstained samples were used as controls. After incubation, the samples were washed twice with PBS (1\% BSA) followed by staining with the corresponding secondary antibody in the dark at RT for 30 mins. Samples with secondary antibody alone were used as controls for each cell line. After incubation, the cells were washed twice with PBS-BSA and resuspended in $300 \mu \mathrm{L}$ PBS for further analysis by flow cytometry. 


\section{Results}

ACE2 is expressed on a variety of cell types

The ACE2 expression level was analysed on cell lines from various tissue, including lung (A549 and Calu-3), skin (HaCaT and A-431), liver (Hep G2), colon (SW48, COLO 205 and Caco-2) and green monkey kidney (Vero E6). The anti-ACE2 antibody showed high affinity to the breast cancer cell line MCF7, and therefore this cell line was included in the study (Figure 2). Vero E6 and HepG2 showed the highest ACE2 expression according to the flow cytometry assessment. The lowest expression of ACE2 was determined on the cell lines A-431 and Caco2 (Figure 2).

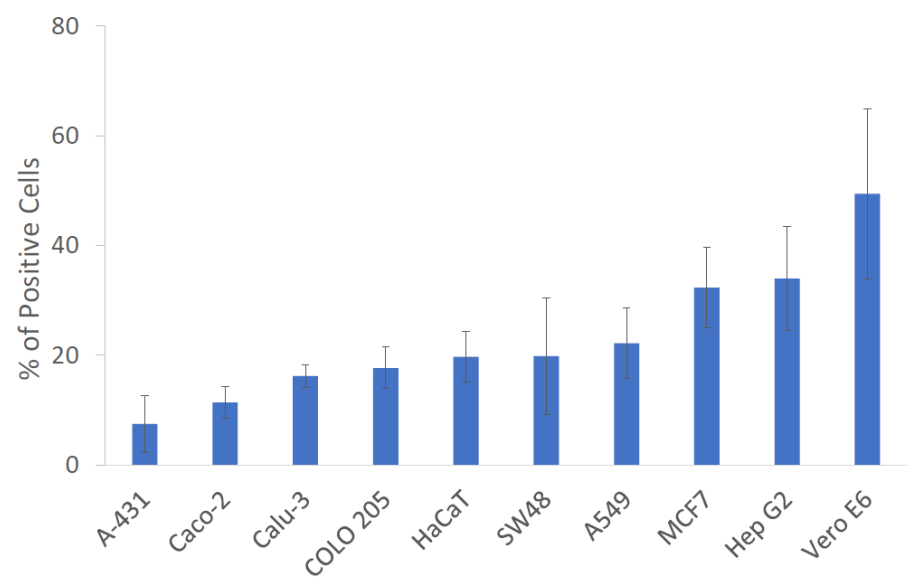

Figure 2. ACE2 expression in a panel of cell lines from tissue susceptible to viral infection. The polyclonal goat anti-ACE2 antibody concentration used was $5 \mu \mathrm{g} / \mathrm{mL}$. Results are shown as percent of cells positive for anti-ACE2 antibody binding using flow cytometry and shown as the mean $+/$ - STDEV of three biological replicates performed as independent experiments.

\section{The polyclonal goat anti-ACE2 antibody shows high specificity to ACE2}

To ensure that the goat anti-ACE2 antibody showed high specificity, a goat isotype control antibody was used to stain the cell lines in parallel with the anti-ACE2 antibody. For this purpose, the five cell lines Caco-2, COLO 205, SW48, MCF7 and Hep G2 were used. The binding pattern of the goat isotype control antibody revealed a lower binding to the cells compared to the binding of the anti-ACE2 antibody (Figure 3a). rACE2 was used for preadsorption experiments with the anti-ACE2 antibody and the goat isotype control antibody, respectively. As positive controls, cells stained with anti-ACE2 antibody or goat isotype control 
antibody alone were used. Those samples showed $22.1 \%$ and $3.3 \%$ positive cell binding as analysed by flow cytometry (Figure 3b). Pre-adsorption with rACE2 showed a high inhibitory effect of the binding capacity of the anti-ACE2 antibody (3.1\%), whereas the inhibitory effect for the goat isotype control antibody was limited (2.4\%) (Figure $3 b$ ).
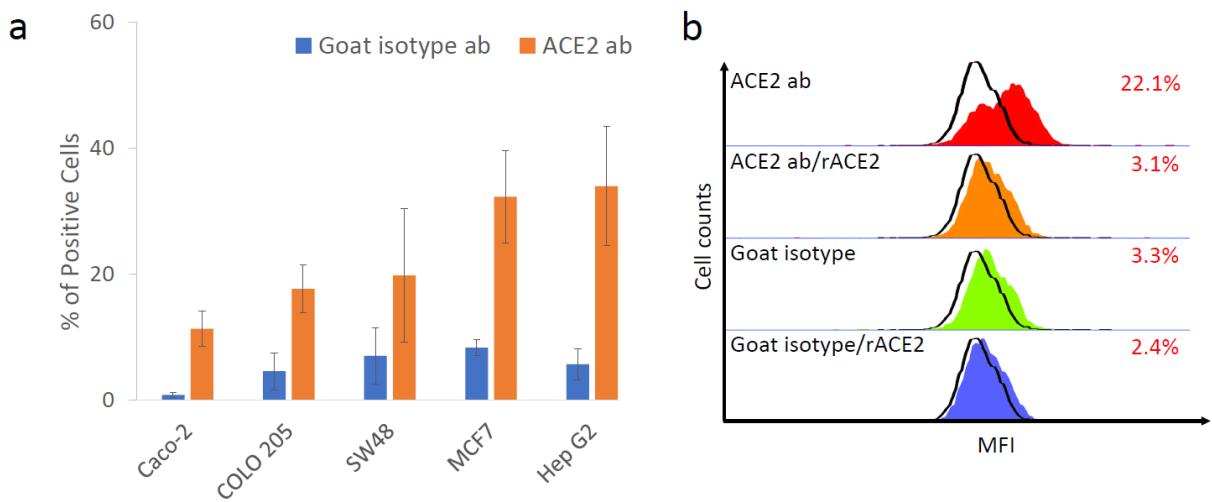

Figure 3. The polyclonal goat anti-ACE2 antibody shows a high degree of specificity for ACE2. a. The cell lines Caco-2, COLO 205, SW48, MCF7, and Hep G2 were stained with the goat isotype control antibody and the polyclonal goat anti-ACE2 antibody concentration at $5 \mu \mathrm{g} / \mathrm{mL}$ b. The cell line MCF7 was pre-adsorbed with or without $2.5 \mu \mathrm{g}$ rACE2 and thereafter incubated with $5 \mu \mathrm{g} / \mathrm{mL}$ anti-ACE2 antibody or with goat isotype control antibody, respectively. Values are expressed as percent of cells positive for anti-ACE2 antibody binding using flow cytometry. The results are shown as the mean $+/-$ STDEV of three biological replicates performed as independent experiments.

\section{Comparison of the binding pattern of RBD-Fc and anti-ACE2 antibody}

Binding of RBD-Fc to the panel of ten cell lines A-431, Caco-2, Calu-3, COLO 205, HaCaT, SW48, A549, MCF7, Hep G2 and Vero E6 was evaluated. COLO 205 and Vero E6 showed high binding to RBD-Fc, while A-431 showed the lowest binding to RBD-Fc as assessed by flow cytometry (Figure 4). 



Figure 4. Histogram (a) and bar chart (b) shows the RBD-Fc binding to the panel of ten cell lines from tissue susceptible to viral infection. The RBD-Fc concentration used was $10 \mu \mathrm{g} / \mathrm{mL}$. Values are expressed as percent of cells positive for RBD-Fc binding using flow cytometry. The results are shown as the mean $+/$ - STDEV of three biological replicates performed as independent experiments.

\section{TMPRSS2 expression in the chosen cell panel}

Expression of the serine protease TMPRSS2 was evaluated on the panel of ten cell lines using an anti-TMPRSS2 antibody. COLO 205 showed a high TMPRSS2 expression, whereas the A431 cell line showed the lowest TMPRSS2 expression (Figure 5).



Figure 5. TMPRSS2 expression in a panel of ten cell lines from tissue susceptible to viral infection. The rabbit anti-TMPRSS2 antibody concentration used is $26 \mu \mathrm{g} / \mathrm{mL}$. Values are expressed as percent of cells positive for anti-TMPRSS2 antibody binding using flow cytometry. The results are shown as the mean +/- STDEV of three biological replicates performed as independent experiments. 
Analysing ACE2 and TMPRSS2 mRNA expression by RT-PCR

ACE2 and TMPRSS2 mRNA expression were analysed by RT-PCR in the human cell lines, including skin epithelial cell line A-431, colon epithelial cell line Caco-2, lung adenocarcinoma epithelial cell line Calu-3, colon epithelial cell line COLO 205, skin keratinocytes cell line HaCaT, colon epithelial cell line SW48, lung epithelial cell line A549, breast epithelial cell line MCF7 and liver epithelial-like cell line Hep G2 (shown in Figure 6). ACTB was used as reference gene.

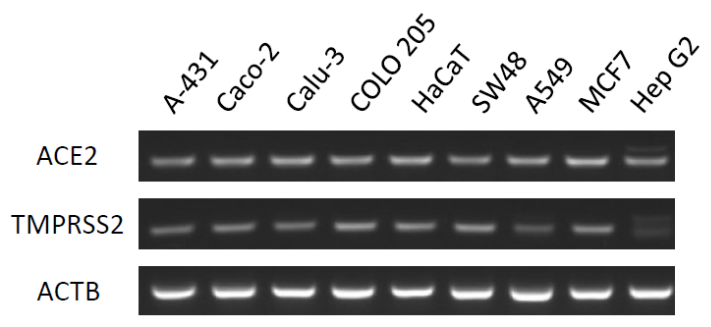

Figure 6. RT-PCR analysis of ACE2 and TMPRSS2 gene expression in human cell lines. ACTB was used as reference gene.

\section{Sialic acid is not involved in the SARS-CoV-2 RBD-ACE2 interaction}

We next evaluated whether SA acts as a co-receptor involved in the binding between RBD and ACE2 on the host cells. First, lung epithelial cell line A549 were treated with neuraminidase to cleave off SA from the cell surface (Figure 7a). Thereafter, two different lectins, MAL I (2,3 SA) SNA (2,6 SA), were used to stain cells with/without neuraminidase treatment. The results verified that SA was successfully removed from the cell surface by showing reduction in lectin binding (Figure $7 \mathrm{~b}$ ). The subsequent evaluation of RBD-Fc binding to neuraminidase treated cells did not show any decrease in binding (Figure 7b), which demonstrates that SA may not be a co-receptor of RBD in the binding to human ACE2. After that, the RBD-Fc were preincubated with SA-derivatives ME0752 and ME0976 (Figure 7c) at concentrations of 20 and $200 \mu \mathrm{M}$ and thereafter incubated with cells. We observed no inhibition effect of the RBD-Fc to the cells (Figure 7d). 



Figure 7. Function of SA in the binding between RBD and human ACE2. a. illustrating the mechanism of neuraminidase. b. A549 cell line was treated with neuraminidase, or left untreated, and thereafter stained with MAL I and SNA, respectively at a concentration of $5 \mu \mathrm{g} / \mathrm{mL}$. The cells were also incubated with $10 \mu \mathrm{g} / \mathrm{mL}$ RBD-FC. c. represents the structure of two inhibitors. d. The cell line MCF7 was preincubated with or without 20 and $200 \mu \mathrm{M}$ of ME0752 and ME0976, respectively, and thereafter incubated with $10 \mu \mathrm{g} / \mathrm{mL}$ of RBD-FC. Values are expressed as percent of positive cells using flow cytometry. The results are shown as the mean +/- STDEV of three biological replicates performed as independent experiments.

\section{Discussion}

ACE2 plays an essential role in the renin-angiotensin system, and it is widely expressed on the surface of epithelial and endothelial cells. ACE2 is also present in soluble form by being released from lung cells, kidney, and the gastrointestinal tract [22]. In this system, ACE2 could hydrolyze Ang II and convert it to Ang-(1-7), resulting in natriuresis, vasodilation, and antiinflammation by activating the Mas receptor [23, 24]. Simultaneously, this process effectively prevend the pro-inflammatory, vasoconstrictive and pro-thrombotic effects by diminishing the availability of Ang II and the following Ang II-AT ${ }_{1} \mathrm{R}$ activation [25]. It has been verified that ACE2 expression may be upregulated in individuals with existing cardiovascular disease [25]. ACE2 also acts as the binding site for viral S protein of both SARS-CoV and SARS-CoV-2. In this study, the expression of ACE2 on the surface of human cell lines, including A549, Calu-3, Caco-2, COLO 205, SW48, HaCaT, Hep G2, A-431 and MCF7 was evaluated. The green 
monkey kidney cell line VeroE6 was included because these cells are widely used for SARS$\mathrm{CoV}$ and SARS-CoV-2 binding/infection studies [26, 27].

Our data demonstrate that Hep G2 (liver), MCF7 (breast), HaCaT (skin), SW48 and COLO 205 (colon) express more ACE2 compared to the lung cell line Calu-3. To test the reliability of our staining results, we used a goat isotype control antibody to investigate the specificity of the binding. Indeed, the data shows that goat isotype control antibody stained much fewer cells compared with polyclonal goat anti-ACE2 antibody, even less than 10\%, indicating low levels of unspecific binding. Moreover, the pre-adsorption assay demonstrated the specificity of the anti-ACE2 antibody and the reliability of the ACE2 receptor expression in this study.

SARS-CoV-2 uses S glycoprotein to attach to the host cells and mediate host cell membrane fusion. The RBD is located in the $\mathrm{S} 1$ region of the $\mathrm{S}$ glycoprotein, and the interaction between $\mathrm{RBD}$ and the receptor ACE2 is a prerequisite for the infection of SARS-CoV-2. Jian et al. demonstrated that SARS-CoV-2 RBD has a higher ACE2 binding affinity than SARS-CoV RBD, which could explain the widespread of SARS-CoV-2 [28]. In our study, we included the anlaysis of the binding between RBD-Fc and several host cells lines that express various levels of surface-bound ACE2. Interestingly, the colon adenocarcinoma COLO 205 and the African green monkey epithelial kidney cell line Vero E6 had a high affinity for RBD-Fc. Moreover, the binding of RBM to the cell lines was determined in our study, but the affinity was lower than $15 \%$ positive cells as assessed by flow cytometry (data not show).

For TMPRSS2 expression, COLO 205 and Calu-3 cells showed high TMPRSS2. As for ACE2 expression, the skin carcinoma cell line A-431 showed the lowest TMPRSS2 expression among these cell lines. As shown in Figure 6, the mRNA expression of ACE2 and TMPRSS2 were further analyzed by RT-PCR. Housekeeping $\beta$-actin gene ACTB was used as standard for normalization.

Heparan sulfate was recently proven to be a co-receptor for RBD, and it was shown to effectively promote the spike-ACE2 interaction [18]. Hence, chondroitinase and heparinase were used to determine if chondroitin and heparin were involved in this interaction. 
Interestingly, we found that the RBD-Fc binding has increased a little after treatment with chondroitinase, indicating that chondroitin might block some of the binding sites on ACE2 and further decreased the binding between RBD-Fc and host cells (data not shown).

To further explore the RBD binding mechanism, we wanted to assess potential glycan receptors. SA is linked to the outermost part of the glycan chains, and has been shown to be the receptor for the influenza virus [29], as well as for many coronaviruses, such as HCoV-OC43 and Middle East respiratory disease (MERS) [19, 30]. In this study, neuraminidase treatment was performed and evaluated by staining with the two lectins MAL I and SNA, binding to the 2,3 and 2,6 linkage sialic acid, respectively, and used to verify that SA was successfully removed from the cell surface. After neuraminidase treatment, we could not determine any change in RBD-Fc binding, which indicates that SA may not be a receptor of RBD. To verify this hypothesis, we pre-incubate the RBD-Fc with two SA-derivative inhibitors (ME0976 and ME0752), which were designed to prevent the binding and infection of adenovirus that utilize SA for cell attachment [31]. The results agree well with the neuraminidase assay and no inhibition effect has been observed, demonstrating that SA is not a co-receptor of RBD.

\section{Conclusions}

To conclude, this study evaluated the ACE2 and TMPRSS2 expression levels in a panel of cell lines from tissues that are susceptible to viral infection. The binding between these cell lines and RBD was further tested, and the results show that the RBD binding was not only dependent on the ACE2 expression level. Moreover, the possible function of SA involved in this interaction has been evaluated, and our results indicate that SA may not be a co-receptor of RBD. This study provides important information on multiple cell lines, which may benefit the follow-up research.

\section{Author contributions}

YZ, ZE, TS and AGW conceived and designed the study. YZ, TS, SB, ZE, and RVL carried out the cell based studies and performed experiments; LO and ZE designed the primers; ZE, SB, YZ, TS, JLP, MS, LO and AGW analyzed the data; KBS, ME, NA, RC, MS, LO and JLP 
provided advice and technical assistance; TS; YZ, ZE, MS, LO and AGW wrote the manuscript. All authors read and approved the final manuscript.

\section{Funding sources}

This study was funded by the European Union's Horizon 2020 research and innovation program under the Marie Sklodowska-Curie grant agreement grant number 721297, the Swedish Knowledge Foundation grant number 20160165, the Malmö Cancer Center, Biofilms Research Center for Biointerfaces and Malmö University.

\section{Notes}

The authors declare that they have no competing interests.

\section{References}

[1] https://www.who.int/emergencies/diseases/novel-coronavirus-2019.

[2] P. Zhou, X.-L. Yang, X.-G. Wang, B. Hu, L. Zhang, W. Zhang, H.-R. Si, Y. Zhu, B. Li, C.L. Huang, A pneumonia outbreak associated with a new coronavirus of probable bat origin, nature 579(7798) (2020) 270-273.

[3] R. Yan, Y. Zhang, Y. Li, L. Xia, Y. Guo, Q. Zhou, Structural basis for the recognition of SARS-CoV-2 by full-length human ACE2, Science 367(6485) (2020) 1444-1448.

[4] S.-L. Liu, L.J. Saif, S.R. Weiss, L. Su, No credible evidence supporting claims of the laboratory engineering of SARS-CoV-2, Emerging Microbes \& Infections 9(1) (2020) 505-507.

[5] C. Wang, Z. Liu, Z. Chen, X. Huang, M. Xu, T. He, Z. Zhang, The establishment of reference sequence for SARS-CoV-2 and variation analysis, Journal of medical virology 92(6) (2020) 667-674.

[6] J. Lan, J. Ge, J. Yu, S. Shan, H. Zhou, S. Fan, Q. Zhang, X. Shi, Q. Wang, L. Zhang, Structure of the SARS-CoV-2 spike receptor-binding domain bound to the ACE2 receptor, Nature 581(7807) (2020) 215-220.

[7] J. Shang, G. Ye, K. Shi, Y. Wan, C. Luo, H. Aihara, Q. Geng, A. Auerbach, F. Li, Structural basis of receptor recognition by SARS-CoV-2, Nature 581(7807) (2020) 221-224. 
[8] S. Xia, Y. Zhu, M. Liu, Q. Lan, W. Xu, Y. Wu, T. Ying, S. Liu, Z. Shi, S. Jiang, Fusion mechanism of 2019-nCoV and fusion inhibitors targeting HR1 domain in spike protein, Cellular \& molecular immunology (2020) 1-3.

[9] W. Li, M.J. Moore, N. Vasilieva, J. Sui, S.K. Wong, M.A. Berne, M. Somasundaran, J.L. Sullivan, K. Luzuriaga, T.C. Greenough, Angiotensin-converting enzyme 2 is a functional receptor for the SARS coronavirus, Nature 426(6965) (2003) 450-454.

[10] Y. Cai, J. Zhang, T. Xiao, H. Peng, S.M. Sterling, R.M. Walsh, S. Rawson, S. Rits-Volloch, B. Chen, Distinct conformational states of SARS-CoV-2 spike protein, Science 369(6511) (2020) 1586-1592.

[11] Y. Huang, C. Yang, X.-f. Xu, W. Xu, S.-w. Liu, Structural and functional properties of SARS-CoV-2 spike protein: potential antivirus drug development for COVID-19, Acta Pharmacologica Sinica 41(9) (2020) 1141-1149.

[12] D. Bestle, M.R. Heindl, H. Limburg, O. Pilgram, H. Moulton, D.A. Stein, K. Hardes, M. Eickmann, O. Dolnik, C. Rohde, TMPRSS2 and furin are both essential for proteolytic activation of SARS-CoV-2 in human airway cells, Life science alliance 3(9) (2020).

[13] M. Hoffmann, H. Kleine-Weber, S. Schroeder, N. Krüger, T. Herrler, S. Erichsen, T.S. Schiergens, G. Herrler, N.-H. Wu, A. Nitsche, SARS-CoV-2 cell entry depends on ACE2 and TMPRSS2 and is blocked by a clinically proven protease inhibitor, cell 181(2) (2020) 271-280. e8.

[14] L. Wang, X. Fan, G. Bonenfant, D. Cui, J. Hossain, N. Jiang, G. Larson, M. Currier, J. Liddell, M. Wilson, SARS-CoV-2 susceptibility of cell lines and substrates commonly used in diagnosis and isolation of influenza and other viruses, bioRxiv (2021) 2021.01. 04.425336.

[15] L. Cantuti-Castelvetri, R. Ojha, L.D. Pedro, M. Djannatian, J. Franz, S. Kuivanen, F. van der Meer, K. Kallio, T. Kaya, M. Anastasina, Neuropilin-1 facilitates SARS-CoV-2 cell entry and infectivity, Science 370(6518) (2020) 856-860.

[16] H. Ulrich, M.M. Pillat, CD147 as a target for COVID-19 treatment: suggested effects of azithromycin and stem cell engagement, Stem cell reviews and reports 16(3) (2020) 434-440.

[17] R. Amraei, M. Napoleon, W. Yin, J. Berrigan, E. Suder, G. Zhao, J. Olejnik, K. Chandler, C. Xia, S. Gummuluru, CD209L/L-SIGN and CD209/DC-SIGN act as receptors for SARSCoV-2 and are differentially expressed in lung and kidney epithelial and endothelial cells, BioRxiv (2020). 
[18] T.M. Clausen, D.R. Sandoval, C.B. Spliid, J. Pihl, H.R. Perrett, C.D. Painter, A. Narayanan, S.A. Majowicz, E.M. Kwong, R.N. McVicar, SARS-CoV-2 infection depends on cellular heparan sulfate and ACE2, Cell 183(4) (2020) 1043-1057. e15.

[19] Y.-J. Park, A.C. Walls, Z. Wang, M.M. Sauer, W. Li, M.A. Tortorici, B.-J. Bosch, F. DiMaio, D. Veesler, Structures of MERS-CoV spike glycoprotein in complex with sialoside attachment receptors, Nature structural \& molecular biology 26(12) (2019) 1151-1157.

[20] C. Schwegmann-Weßels, G. Herrler, Sialic acids as receptor determinants for coronaviruses, Glycoconjugate journal 23(1) (2006) 51-58.

[21] D. Ma, C.-B. Chen, V. Jhanji, C. Xu, X.-L. Yuan, J.-J. Liang, Y. Huang, L.-P. Cen, T.K. $\mathrm{Ng}$, Expression of SARS-CoV-2 receptor ACE2 and TMPRSS2 in human primary conjunctival and pterygium cell lines and in mouse cornea, Eye 34(7) (2020) 1212-1219.

[22] M. Donoghue, F. Hsieh, E. Baronas, K. Godbout, M. Gosselin, N. Stagliano, M. Donovan, B. Woolf, K. Robison, R. Jeyaseelan, A novel angiotensin-converting enzyme-related carboxypeptidase (ACE2) converts angiotensin I to angiotensin 1-9, Circulation research 87(5) (2000) e1-e9.

[23] A.M. South, H.A. Shaltout, L.K. Washburn, A.S. Hendricks, D.I. Diz, M.C. Chappell, Fetal programming and the angiotensin-(1-7) axis: a review of the experimental and clinical data, Clinical Science 133(1) (2019) 55-74.

[24] D. de Farias Lelis, D.F. de Freitas, A.S. Machado, T.S. Crespo, S.H.S. Santos, Angiotensin-(1-7), adipokines and inflammation, Metabolism 95 (2019) 36-45.

[25] J.B. Cohen, T.C. Hanff, A.P. Bress, A.M. South, Relationship between ACE2 and other components of the renin-angiotensin system, Current Hypertension Reports 22(7) (2020) 1-5.

[26] S. Matsuyama, N. Nao, K. Shirato, M. Kawase, S. Saito, I. Takayama, N. Nagata, T. Sekizuka, H. Katoh, F. Kato, Enhanced isolation of SARS-CoV-2 by TMPRSS2-expressing cells, Proceedings of the National Academy of Sciences 117(13) (2020) 7001-7003.

[27] N.S. Ogando, T.J. Dalebout, J.C. Zevenhoven-Dobbe, R.W. Limpens, Y. van der Meer, L. Caly, J. Druce, J.J. de Vries, M. Kikkert, M. Bárcena, SARS-coronavirus-2 replication in Vero E6 cells: replication kinetics, rapid adaptation and cytopathology, The Journal of general virology 101(9) (2020) 925.

[28] J. Shang, Y. Wan, C. Luo, G. Ye, Q. Geng, A. Auerbach, F. Li, Cell entry mechanisms of SARS-CoV-2, Proceedings of the National Academy of Sciences 117(21) (2020) 11727-11734. 
[29] W. Weis, J. Brown, S. Cusack, J. Paulson, J. Skehel, D. Wiley, Structure of the influenza virus haemagglutinin complexed with its receptor, sialic acid, Nature 333(6172) (1988) 426431.

[30] M.A. Tortorici, A.C. Walls, Y. Lang, C. Wang, Z. Li, D. Koerhuis, G.-J. Boons, B.-J. Bosch, F.A. Rey, R.J. de Groot, Structural basis for human coronavirus attachment to sialic acid receptors, Nature structural \& molecular biology 26(6) (2019) 481-489.

[31] R. Caraballo, M. Saleeb, J. Bauer, A.M. Liaci, N. Chandra, R.J. Storm, L. Frängsmyr, W. Qian, T. Stehle, N. Arnberg, Triazole linker-based trivalent sialic acid inhibitors of adenovirus type 37 infection of human corneal epithelial cells, Organic \& biomolecular chemistry 13(35) (2015) 9194-9205. 


\section{Malmö University Health and Society Doctoral Dissertations}

Ross, M. W. Typing, doing and being. A study of men who have sex with men and sexuality on the Internet. 2006:1

Stoltz, P. Searching for meaning of support in nursing. A study on support in family care of frail aged persons with examples from palliative care at home. 2006:2

Gudmundsson, P. Detection of myocardial ischemia using real-time myocardial contrasts echocardiograpy. 2006:3

Holmberg, L. Communication in palliative home care, grief and bereavement. A mother's experiences. 2007:1

Ny, P. Swedish maternal health care in a multiethnic society - including the fathers. 2007:2

Schölin, T. Etnisk mångfald som organisationsidé. Chefs- och personalpraktiker i äldreomsorgen. 2008:1

Svensson, O. Interactions of mucins with biopolymers and drug delivery particles. 2008:2

Holst, M. Self-care behaviour and daily life experiences in patients with chronic heart failure. 2008:3

Bahtsevani, C. In search of evidence-based practices. Exploring factors influencing evidence based practice and implementation of clinical practice guidelines. 2008:4

Andersson, L. Endocytosis by human dendritic cells. 2009:1

Svendsen, I. E. In vitro and in vivo studies of salivary films at solid/liquid interfaces. 2009:2

Persson, K. Oral health in an outpatient psychiatric population. Oral status, life satisfaction and support. 2009:3

Hellman, P. Human dendritic cells. A study of early events during pathogen recognition and antigen endocytosis. 2009:4

Baghir-Zada, R. Illegal aliens and health (care) wants. The cases of Sweden and the Netherlands. 2009:5

Stjernswärd, S. Designing online support for families living with depression. 2009:6

Carlsson, A. Child injuries at home - prevention, precautions and intervention with focus on scalds. 2010:1

Carlson, E. Sjuksköterskan som handledare. Innehåll i och förutsättningar för sjuksköterskors handledande funktion i verksamhetsförlagd utbildning - en etnografisk studie. 2010:2

Sinkiewicz, G. Lactobacillus reuteri in health and disease. 2010:3

Tuvesson, H. Psychiatric nursing staff and the workplace. Perceptions of the ward atmosphere, psychosocial work environment, and stress. 2011:1

Ingvarsdotter, K. Mental ill health and diversity. Researching human suffering and resilience in a multicultural context. 2011:2 
Hamit-Eminovski, J. Interactions of biopolymers and metal complexes at biological interfaces. 2011:3

Mellgren, C. What's neighbourhood got to do with it? The influence of neighbourhood context on crime and reactions to crime. 2011:4

Annersten Gershater, M. Prevention of foot ulcers in patients with diabetes mellitus. Nursing in outpatient settings. 2011:5

Pooremamali P. Culture, occupation and occupational therapy in a mental care context- the challenge of meeting the needs of Middle Eastern immigrants. 2012:1

Gustafsson A. Aspects on sepsis: treatment and markers. 2012:2

Lavant, E. Multiplex HLA-DR-DQ genotyping. For genetic epidemiology and clinical risk assessment. 2012:3

Wangel, A-M. Mental ill-health in childbearing women. Markers and risk factors. 2012:4

Scaramuzzino, R. Equal opportunities? - A cross-national comparison of immigrant organisations in Sweden and Italy. 2012:5

Ivert, A-K. Adolescent mental health and utilisation of psychiatric care - The role of parental country of birth and neighbourhood of residence 2013:1

Znamenskaya, Y. Effect of hydration on thermodynamic, rheological and structural properties of mucin. 2013:2

Andersson, F. The female offender. Patterning of antisocial and criminal activity over the lifecourse. 2013:3

Lindroth, M. Utsatthet och sexuell hälsa - en studie om unga på statliga ungdomshem. 2013:4

Hulusjö, A. The multiplicities of prostitution experience - narratives about power and resistance. 2013:5

Falk, M. Direct electron transfer based biofuel cells. Operation in vitro and in vivo. 2014:1

Finnbogadóttir, H. Exposure to domestic violence during pregnancy. Impact on outcome, midwives' awareness, women's experience and prevalence in the south of Sweden. 2014:2

Fagerström, A. Effects of surfactant adjuvants on barrier properties of plant leaf cuticle. 2014:3

Lamberg, P. Design and characterization of direct electron transfer based biofuel cells including tests in cell cultures. 2014:4

Richert, T. Överdoser, försörjningsstrategier och riskhantering - livsvillkor för personer som injicerar narkotika. 2014:5

Örmon, K. Experiences of abuse during the life course. - Disclosure and the care provided among women in a general psychiatric context. 2014:6

Sjöblom, I. Planerade hemförlossningar i Norden - kvinnors och barnmorskors perspektiv. 2014:7

Albèr, C. Humectants and Skin - Effects of hydration from molecule to man. 2015:1 
Kisch M., A. Allogeneic stem cell transplantation. - Patients' and sibling donors' perspectives. 2015:2

Weiber, I. Children in families where the mother has an intellectual or developmental disability - incidence, support and first person perspectives. 2015:3

Schlyter, M. Myocardial infarction, Personality factors, Coping strategies, Depression and Secondary prevention 2016:1

Carlström, C. BDSM - Paradoxernas praktiker. 2016:2

El-Schich, Z. Novel imaging technology and tools for biomarker detection in cancer. 2016:3

Boonsatean, W. Living with type 2 diabetes in Thai population: Experiences and socioeconomic characteristics. 2016:4

Vejzovic, V. Going through a colonoscopy and living with inflammatory bowel disease: Children's and parents' experiences and evaluation of the bowel cleansing quality prior to colonoscopy. 2016:5

Isma, G.E. Overweight and obesity in young children: Preventive work in child health care with focus on nurses' perceptions and parental risk factors. 2016:6

Brännvall, M. Frigörelse med förhinder - Om polisanmälan när kvinnor tar sig ur mäns våld i nära relationer. 2016:7

Pankratov, D. Self-charging biosupercapacitors. 2016:8

Guidi, P. Social work assessment of families with children at risk: Similarities and differences in Italian and Swedish public social services. 2016:9

Jakobsson, J. The process of recovery after colorectal cancer surgery: Patients' experiences and factors of influence. 2017:1

Gerell, M. Neighborhoods without community. Collective efficacy and crime in Malmö, Sweden. 2017:2

Wierzbicka, C. New fractionation tools targeting elusive post-translational modifications. 2017:3

Afzelius, M. Families with parental mental illness: Supporting children in psychiatric and social services. 2017:4

Nordgren, J. Making drugs ethnic - Khat and minority drug use in Sweden. 2017:5

Nilsson, E-L. Parental socialization and adolescent offending. 2017:6

Sixtensson, J. Härifrån till framtiden. Om gränslinjer, aktörskap och motstånd i tjejers vardagsliv. 2018:1

Vasiljevic, Z. Ambulatory risk assessment and intervention in the prison services. Using Interactive Voice Response to assess and intervene on acute dynamic risk among prisoners on parole. 2018:2

González Arribas, E. Flexible and transparent biological electric power sources based on nano-structured electrodes. 2018:3 
Svalin, K. Risk assessment of intimate partner violence in a police setting. Reliability and predictive accuracy. 2018:4

Andersson, M. Hate crime victimization: consequences and interpretations. 2018:5

Djampour, P. Borders crossing bodies. The stories of eight youth with experience of migrating 2018:6

Yeung, S.Y. Stimuli-responsive lipid bilayer mimics for protein, virus and cell recognition. 2018:7

Holst-Hansson, A. On a journey for survival: everyday life during radiation therapy from the perspectives of women with breast cancer and their families. 2018:8

Berlin Hallrup, L. Experiences of Everydaylife and Participation for People with Intellectual Disabilities -From four Perspectives. 2019:1

Aleksejeva, O. Blue copper proteins as bioelements for bioelectronics devices 2019:2

Wendel, L. Dokumentation, profession och hälso- och sjukvård. Rättsliga perspektiv. 2019:3

Larsson, H. Existentiell ensamhet hos sköra äldre personer: ett närståendeperspektiv. 2020:1

Sundström, M. Existentiell ensamhet hos sköra äldre personer: Vårdpersonals och volontärers erfarenheter och behov av stöd. 2020:2.

Kvist, M. Varken resurs eller problem. Om lågutbildade ungas etablerings- och försörjningsmöjligheter. 2020:3.

Waldie, S. Model Membranes and Their Interactions with Native and Artificial Lipoproteins 2020:4

Sjöberg, M. Existentiell ensamhet hos sköra äldre personer: Äldre personers upplevelser samt dokumentation i patientjournalen. 2020:5

Samzelius, T. A vicious circle of silent exclusion: Family homelessness and poverty in Sweden from a single-mother perspective. 2020:6

Hylén, M. Pain in Intensive Care: assessments and patients' experiences. 2021:1

Engström, A. Everyday life, crime, and fear of crime among adolescents and young adults. 2021:2

Ali, A. Topical formulations, design and drug delivery: A dive into water. 2021:3

Mavliutova, L. Molecularly imprinted micro- and nanoparticles for cancer associated glycan motifs. 2021:4

Incel, A. Amino acid sequence and side chain specific synthetic receptors targeting protein phosphorylation. 2021:5

Andersson, L. Problematisk opioidanvändning. Om opioidrelaterade dödsfall och LARO i södra Sverige. 2021:6

Yuecheng, Z. Glycosylation in cancer and infection - the role of sialic acid. 2021:7

The publications are available on-line. https://mau.diva-portal.org/ 

ISBN 978-91-7877-220-9 (print)

ISBN 978-91-7877-221-6 (pdf)

ISSN 1653-5383

MALMÖ UNIVERSITY

20506 MALMÖ, SWEDEN

WWW.MAU.SE 